Supporting Information for

\title{
Co(III)-Catalyzed, Internal and Terminal Alkyne-Compatible Synthesis of Indoles
}

Shuguang Zhou, Jinhu Wang, Lili Wang, Kehao Chen, Chao Song, and Jin Zhu*

Department of Polymer Science and Engineering, School of Chemistry and Chemical Engineering, State Key Laboratory of Coordination Chemistry, Nanjing National Laboratory of Microstructures, Nanjing University, Nanjing 210093, China

*Corresponding author. Email: jinz@nju.edu.cn; Phone: +86-25-83686291;

Fax: +86-25-83317761 


\section{Supporting Information}

\section{Table of Contents}

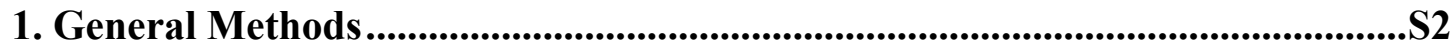

2. Reaction Development ..............................................................................S2

3. Competition Experiment ..........................................................................................

4. Kinetic Isotope Effect Experiments........................................................S10

5. Relationship between Alkyne and Allene in Catalytic Mechanism..................S13

6. Large Scale Synthesis of 3a ..........................................................................S16

7. Transformations of 5a ..............................................................................................S17

8. Synthesis of $N$-methylphenylhydrazines ...............................................S20

9. Synthesis and Characterization of Indole Derivatives ..................................S20

10. General Procedure for the Synthesis of Indole Derivatives .........................S27

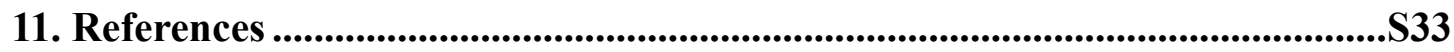

12. NMR Spectra for All the Compounds ......................................................S34 


\section{General Methods}

\section{Materials:}

All reagents and solvents were purchased from commercial sources and used without further purification unless otherwise stated. HPLC grade $\mathrm{CH}_{3} \mathrm{OH}$ was used directly. Toluene and THF were freshly distilled over $\mathrm{Na}$ /benzophenone before use. $\left[\mathrm{Cp}^{*} \mathrm{CoI}_{2}\right]_{2}, \quad\left[\mathrm{Cp} * \mathrm{Co}(\mathrm{CO}) \mathrm{I}_{2}\right]_{2}, \quad\left[\mathrm{Cp}^{*} \mathrm{CoCl}_{2}\right]_{2}$ and $\left[\mathrm{Cp} * \mathrm{Co}\left(\mathrm{CH}_{3} \mathrm{CN}\right)_{3}\right]\left[\mathrm{SbF}_{6}\right]_{2}$ were synthesized according to the literature procedures, ${ }^{1}$ stored and weighed in an argon-filled glovebox. All other chemicals were obtained from local suppliers or synthesized according to the literature procedures.

\section{Methods:}

All $\left[\mathrm{Cp}^{*} \mathrm{CoI}_{2}\right]_{2}$-catalyzed reactions were carried out without any particular precautions to extrude moisture or oxygen. All reactions beyond room temperature (rt) were run in oil baths with the temperature calibrated with a thermometer. Prior to an experiment, the oil bath was allowed to equilibrate to the desired temperature for 15 min. ${ }^{1} \mathrm{H}$ and ${ }^{13} \mathrm{C}$ NMR spectra were recorded in $\mathrm{CDCl}_{3}$ (with tetramethylsilane as internal standard) solution on a Bruker AVANCE $400 \mathrm{MHz}$ spectrometer. The following notations were used: $\mathrm{br}$ - broad, $\mathrm{s}$ - singlet, $\mathrm{d}$ - doublet, $\mathrm{t}$ - triplet, $\mathrm{q}-$ quartet, $\mathrm{m}$ - multiplet, $\mathrm{dd}$ - doublet of doublet, $\mathrm{dt}$ - doublet of triplet, $\mathrm{td}$ - triplet of doublet, ddd - doublet of doublet of doublet. High-resolution MS (HRMS) spectra were obtained on a Waters Micromass GCT Premier facility.

\section{Reaction Development}

\subsection{General procedure for the reaction development:}

Table S1. Selected observations from initial screening of solvent. ${ }^{a, b}$<smiles>CN(N)c1ccccc1</smiles> 


\begin{tabular}{ccc}
\hline entry & solvent & yield $(\%)^{b}$ \\
\hline 1 & Toluene & 15 \\
2 & $\mathrm{DCE}$ & 33 \\
3 & $\mathrm{CHCl}_{3}$ & trace \\
4 & $\mathrm{MeCN}$ & trace \\
5 & $\mathrm{MeOH}$ & 12 \\
6 & 1,4-dioxane & 10
\end{tabular}

${ }^{a}$ Conditions: 1a (0.4 mmol, 1 equiv), 2a (1.5 equiv) solvent $(2.0 \mathrm{~mL}), \mathrm{KOAc}\left(2.0\right.$ equiv). ${ }^{b}$ Isolated yields.

To $13 \times 150 \mathrm{~mm}$ test tubes equipped with magnetic stir bar were added KOAc (78.5 mg, $0.8 \mathrm{mmol}, 2.0$ equiv) and $2 \mathrm{a}$ (106.5 mg, $0.60 \mathrm{mmol}, 1.5$ equiv). The test tube was transferred to a glovebox, and then $\left[\mathrm{Cp}^{*} \mathrm{CoI}_{2}\right]_{2}(7.2 \mathrm{mg}, 0.008 \mathrm{mmol}, 2$ mol\%), $\operatorname{AgSbF}_{6}(11 \mathrm{mg}, 0.032 \mathrm{mmol}, 8 \mathrm{~mol} \%$ ) were further added. The test tube was sealed with a rubber septum and removed from the glovebox. A solution of 1a (48.9 $\mathrm{mg}, 0.40 \mathrm{mmol}, 1.0$ equiv) in $2.0 \mathrm{~mL}$ of solvent was injected into the test tube via syringe. The reaction mixture was placed in a pre-heated oil bath and stirred for $12 \mathrm{~h}$ at $60{ }^{\circ} \mathrm{C}$, during which time a constant checking by TLC was performed. The reaction mixture was cooled to room temperature and filtered over celite. The solvent was then removed under reduced pressure and the residue was purified by flash column chromatography on silica gel with 50:1 hexanes/EtOAc as the eluent.

Table S2. Selected observations from initial screening of additive. ${ }^{a, b}$
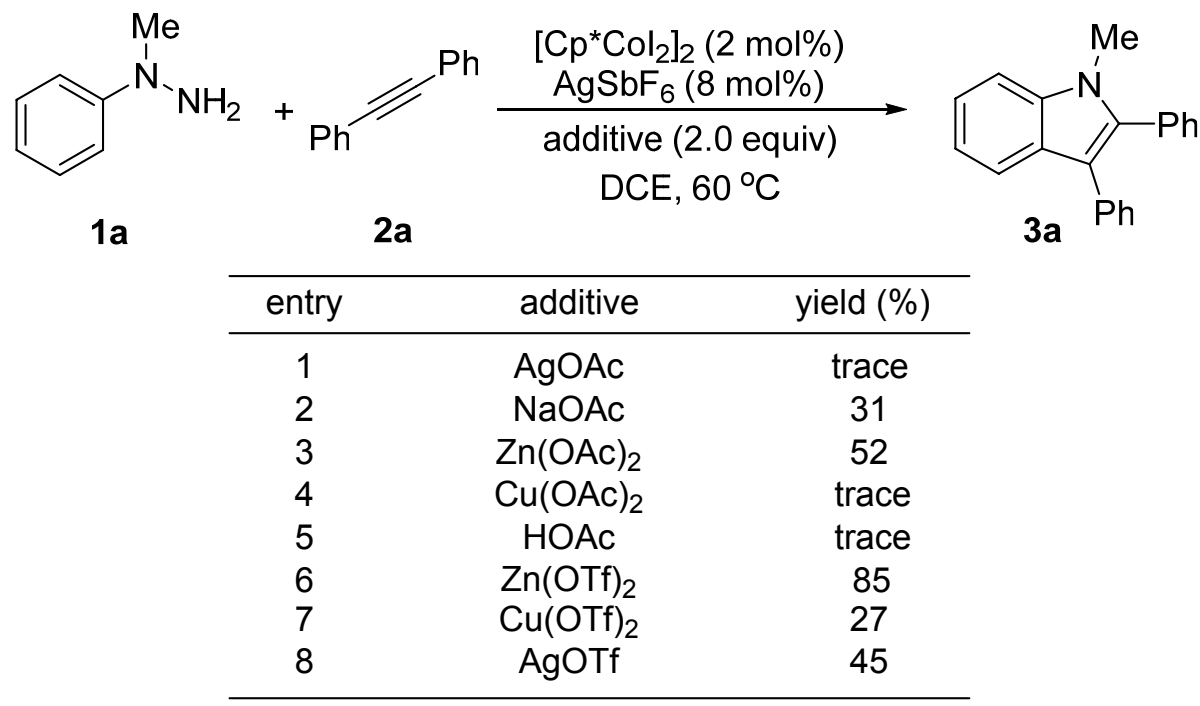

${ }^{a}$ Conditions: 1 a ( $0.4 \mathrm{mmol}, 1$ equiv), 2 a (1.5 equiv)

DCE $(2.0 \mathrm{~mL})$, all the additives (2.0 equiv).

${ }^{b}$ Isolated yields.

To a $13 \times 150 \mathrm{~mm}$ test tube equipped with magnetic stir bar were added 2a (106.5 mg, $0.60 \mathrm{mmol}, 1.5$ equiv) with respective additive as follows: AgOAc (133.5 mg, $0.8 \mathrm{mmol}, 2.0$ equiv), $\mathrm{NaOAc}$ ( $65.6 \mathrm{mg}, 0.8 \mathrm{mmol}, 2.0$ equiv), $\mathrm{Zn}(\mathrm{OAc})_{2}$ (146.8 $\mathrm{mg}, 0.8 \mathrm{mmol}, 2.0$ equiv), $\mathrm{Cu}(\mathrm{OAc})_{2}(160 \mathrm{mg}, 0.8 \mathrm{mmol}, 2.0$ equiv), HOAc (46 $\mu \mathrm{L}$, $0.8 \mathrm{mmol}, 2$ equiv), $\mathrm{Zn}(\mathrm{OTf})_{2}\left(290 \mathrm{mg}, 0.8 \mathrm{mmol}, 2.0\right.$ equiv), $\mathrm{Cu}(\mathrm{OTf})_{2}$ (289 mg, 0.8 mmol, 2.0 equiv), AgOTf (206 $\mathrm{mg}, 0.8 \mathrm{mmol}, 2.0$ equiv). The test tube was 
transferred to a glovebox, and then $\left[\mathrm{Cp}^{*} \mathrm{CoI}_{2}\right]_{2}(7.2 \mathrm{mg}, 0.008 \mathrm{mmol}, 2 \mathrm{~mol} \%)$, $\mathrm{AgSbF}_{6}(11 \mathrm{mg}, 0.032 \mathrm{mmol}, 8 \mathrm{~mol} \%)$ were further added. The test tube was sealed with a rubber septum and removed from the glovebox. A solution of 1a (48.9 mg, 0.4 mmol, 1 equiv) in $2.0 \mathrm{~mL}$ of solvent was injected into the test tube via syringe. The reaction mixture was placed in a pre-heated oil bath and stirred for $12 \mathrm{~h}$ at $60{ }^{\circ} \mathrm{C}$, during which time a constant checking by TLC was performed. The reaction mixture was cooled to room temperature and filtered over celite. The solvent was then removed under reduced pressure and the residue was purified by flash column chromatography on silica gel with 50:1 hexanes/EtOAc as the eluent.

Table S3. Selected observations from initial screening of additive. ${ }^{a, b}$

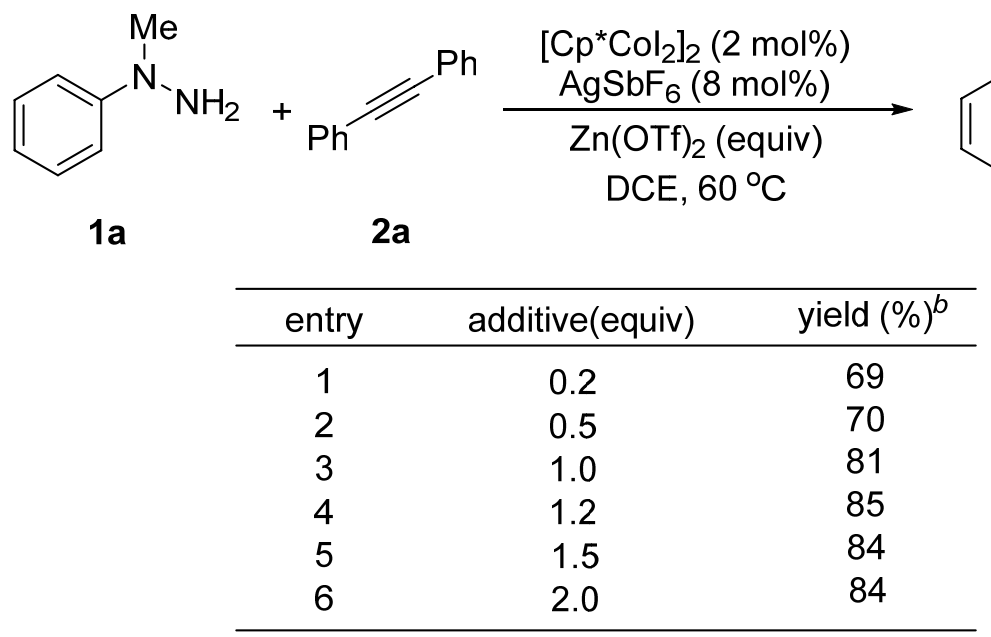

${ }^{a}$ Conditions: $\mathbf{1 a}$ ( $0.4 \mathrm{mmol}, 1$ equiv), $\mathbf{2 a}$ (1.5 equiv) $\mathrm{DCE}(2.0 \mathrm{~mL}), \mathrm{Zn}(\mathrm{OTf})_{2}$ (equiv). ${ }^{b}$ Isolated yields.

To a $13 \times 150 \mathrm{~mm}$ test tube equipped with magnetic stir bar were added 2a ( $106.5 \mathrm{mg}, 0.60 \mathrm{mmol}, 1.5$ equiv) with different equivalents of additive as follows: $\mathrm{Zn}(\mathrm{OTf})_{2}\left(29 \mathrm{mg}, 0.08 \mathrm{mmol}, 0.2\right.$ equiv), $\mathrm{Zn}(\mathrm{OTf})_{2}(72 \mathrm{mg}, 0.2 \mathrm{mmol}, 0.5$ equiv), $\mathrm{Zn}(\mathrm{OTf})_{2}\left(145 \mathrm{mg}, 0.4 \mathrm{mmol}, 1.0\right.$ equiv), $\mathrm{Zn}(\mathrm{OTf})_{2}(174 \mathrm{mg}, 0.48 \mathrm{mmol}, 1.2$ equiv), $\mathrm{Zn}(\mathrm{OTf})_{2}\left(217 \mathrm{mg}, 0.6 \mathrm{mmol}, 1.5\right.$ equiv) and $\mathrm{Zn}(\mathrm{OTf})_{2}(290 \mathrm{mg}, 0.8 \mathrm{mmol}, 2.0$ equiv), respectively. The test tube was transferred to a glovebox, and then $\left[\mathrm{Cp}^{*} \mathrm{CoI}_{2}\right]_{2}(7.2 \mathrm{mg}$, $0.008 \mathrm{mmol}, 2 \mathrm{~mol} \%), \mathrm{AgSbF}_{6}(11 \mathrm{mg}, 0.032 \mathrm{mmol}, 8 \mathrm{~mol} \%)$ were further added. The test tube was sealed with a rubber septum and removed from the glovebox. A solution of 1a ( $48.9 \mathrm{mg}, 0.40 \mathrm{mmol}, 1.0$ equiv) in $2.0 \mathrm{~mL}$ of solvent was injected into the test tube via syringe. The reaction mixture was stirred for $12 \mathrm{~h}$ at $60{ }^{\circ} \mathrm{C}$, during which time a constant checking by TLC was performed. The reaction mixture was cooled to room temperature and filtered over celite. The solvent was then removed under reduced pressure and the residue was purified by flash column chromatography on silica gel with 50:1 hexanes/EtOAc as the eluent. 
Table S4. Selected observations from initial screening of temperature. ${ }^{a, b}$

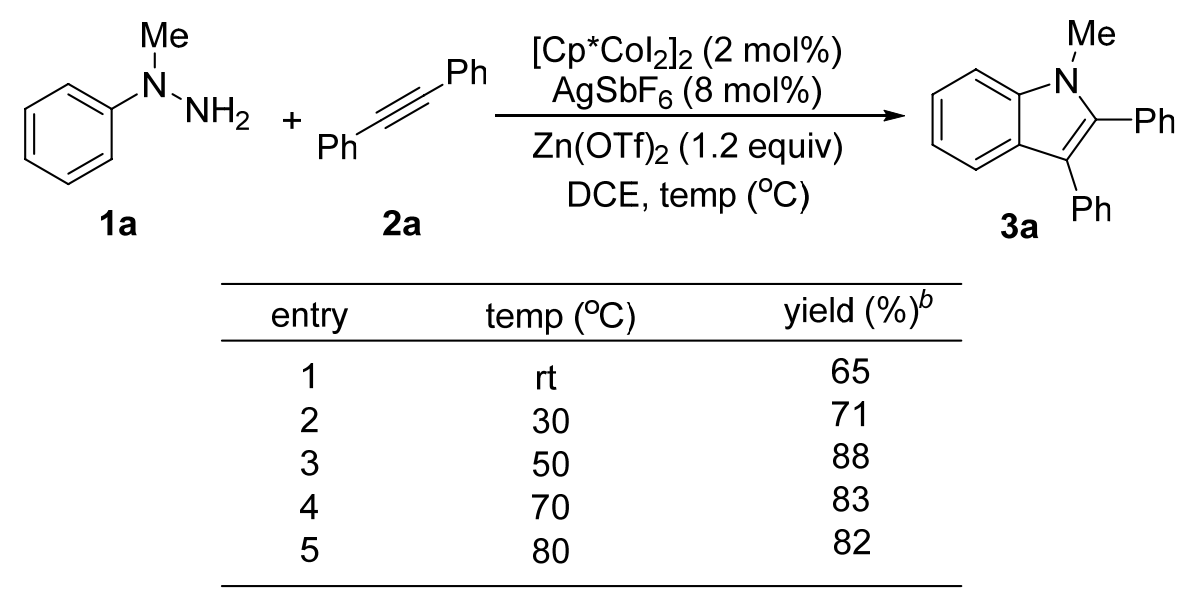

\footnotetext{
${ }^{a}$ Conditions: $\mathbf{1 a}$ ( $0.4 \mathrm{mmol}, 1$ equiv), $\mathbf{2 a}$ (1.5 equiv) solvent $(2.0 \mathrm{~mL}), \mathrm{Zn}(\mathrm{OTf})_{2}$ (1.2 equiv). ${ }^{\text {II }}$ Isolated yields.
}

To a $13 \times 150 \mathrm{~mm}$ test tube equipped with magnetic stir bar were added $\mathrm{Zn}(\mathrm{OTf})_{2}(174 \mathrm{mg}, 0.48 \mathrm{mmol}, 1.2$ equiv) and $\mathbf{2 a}$ (106.5 mg, $0.60 \mathrm{mmol}, 1.5$ equiv). The test tube was transferred to a glovebox, and then $\left[\mathrm{Cp}^{*} \mathrm{CoI}_{2}\right]_{2}(7.2 \mathrm{mg}, 0.008 \mathrm{mmol}$, $\left.2 \mathrm{~mol}^{\circ}\right), \mathrm{AgSbF}_{6}(11 \mathrm{mg}, 0.032 \mathrm{mmol}, 8 \mathrm{~mol} \%$ ) were further added. The test tube was sealed with a rubber septum and removed from the glovebox. A solution of 1a ( $48.9 \mathrm{mg}, 0.40 \mathrm{mmol}, 1.0$ equiv) in $2.0 \mathrm{~mL}$ of solvent was injected into the test tube via syringe. The reaction mixture was stirred for $12 \mathrm{~h}$ at different temperature as follows: room temperature, $30{ }^{\circ} \mathrm{C}, 50{ }^{\circ} \mathrm{C}, 70{ }^{\circ} \mathrm{C}$ and $80{ }^{\circ} \mathrm{C}$, respectively, during which time a constant checking by TLC was performed. The reaction mixture was cooled to room temperature and filtered over celite. The solvent was then removed under reduced pressure and the residue was purified by flash column chromatography on silica gel with 50:1 hexanes/EtOAc as the eluent.

Table S5. Selected observations from initial screening of catalyst. ${ }^{a, b, c}$

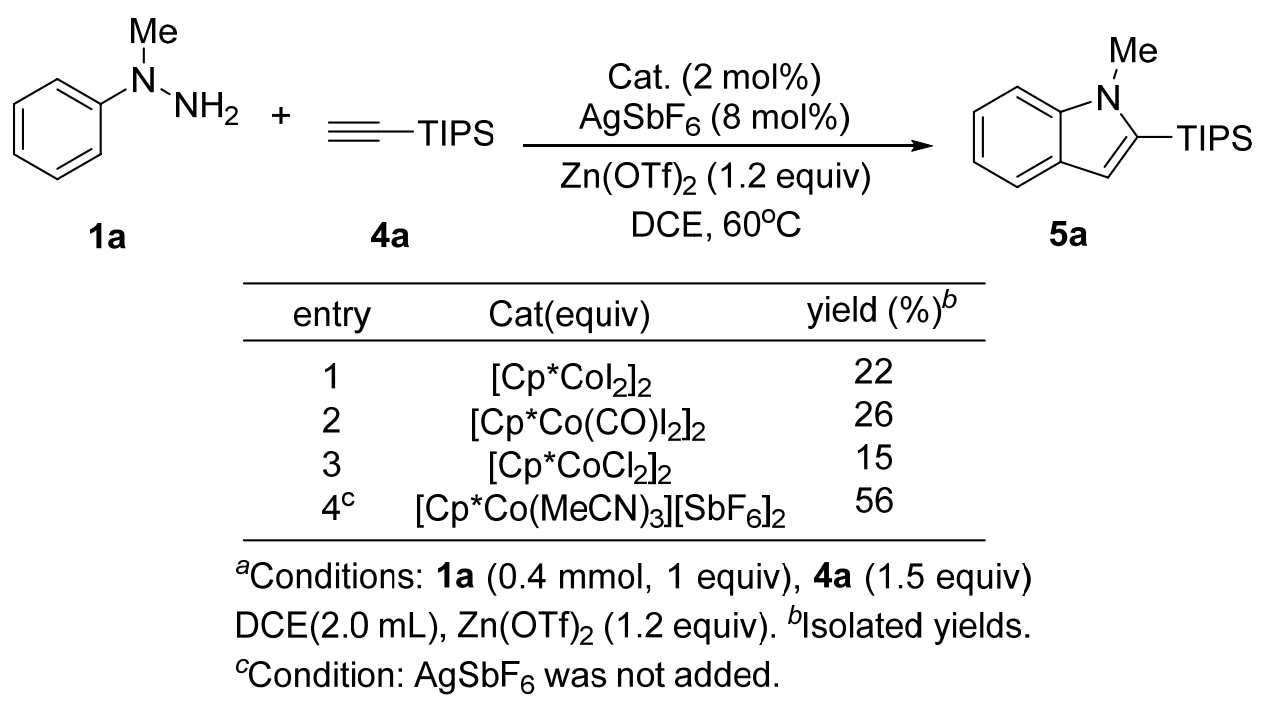


To a $13 \times 150 \mathrm{~mm}$ test tube equipped with magnetic stir bar was added $\mathrm{Zn}(\mathrm{OTf})_{2}$ (174 $\mathrm{mg}, 0.48 \mathrm{mmol}, 1.2$ equiv). The test tube was transferred to a glovebox, and then catalysts as follows: $\left[\mathrm{Cp}^{*} \mathrm{CoI}_{2}\right]_{2}(7.2 \mathrm{mg}, 0.008 \mathrm{mmol}, 2 \mathrm{~mol} \%) / \mathrm{AgSbF}_{6}(11 \mathrm{mg}$, $0.032 \mathrm{mmol}, 8 \mathrm{~mol} \%)$, [Cp* $\left.\mathrm{Co}(\mathrm{CO}) \mathrm{I}_{2}\right]_{2}(7.6 \mathrm{mg}, 0.008 \mathrm{mmol}, 2 \mathrm{~mol} \%) / \mathrm{AgSbF}_{6}(11$ $\mathrm{mg}, 0.032 \mathrm{mmol}, 8 \mathrm{~mol} \%)$, [Cp* $\left.\mathrm{CoCl}_{2}\right]_{2}(4.3 \mathrm{mg}, 0.008 \mathrm{mmol}, 2 \mathrm{~mol} \%) / \operatorname{AgSbF}_{6}(11$ $\mathrm{mg}, 0.032 \mathrm{mmol}, 8 \mathrm{~mol} \%)$ and $\left[\mathrm{Cp}^{*} \mathrm{Co}\left(\mathrm{CH}_{3} \mathrm{CN}\right)_{3}\right]\left[\mathrm{SbF}_{6}\right]_{2}(6.3 \mathrm{mg}, 0.008 \mathrm{mmol}, 2$ $\mathrm{mol} \%$ ) were further added, respectively. The test tube was sealed with a rubber septum and removed from the glovebox. A solution of $1 \mathrm{a}(48.9 \mathrm{mg}, 0.40 \mathrm{mmol}, 1.0$ equiv) and 4 a (109.2 mg, $0.60 \mathrm{mmol}, 1.5$ equiv) in $2.0 \mathrm{~mL}$ of DCE was injected into the test tube via syringe. The reaction mixture was stirred for $12 \mathrm{~h}$ at $60{ }^{\circ} \mathrm{C}$, during which time a constant checking by TLC was performed. The reaction mixture was cooled to room temperature and filtered over celite. The solvent was then removed under reduced pressure and the residue was purified by flash column chromatography on silica gel with 100:1 hexanes/EtOAc as the eluent.

Table S6. Selected observations from initial screening of additive. ${ }^{a, b}$

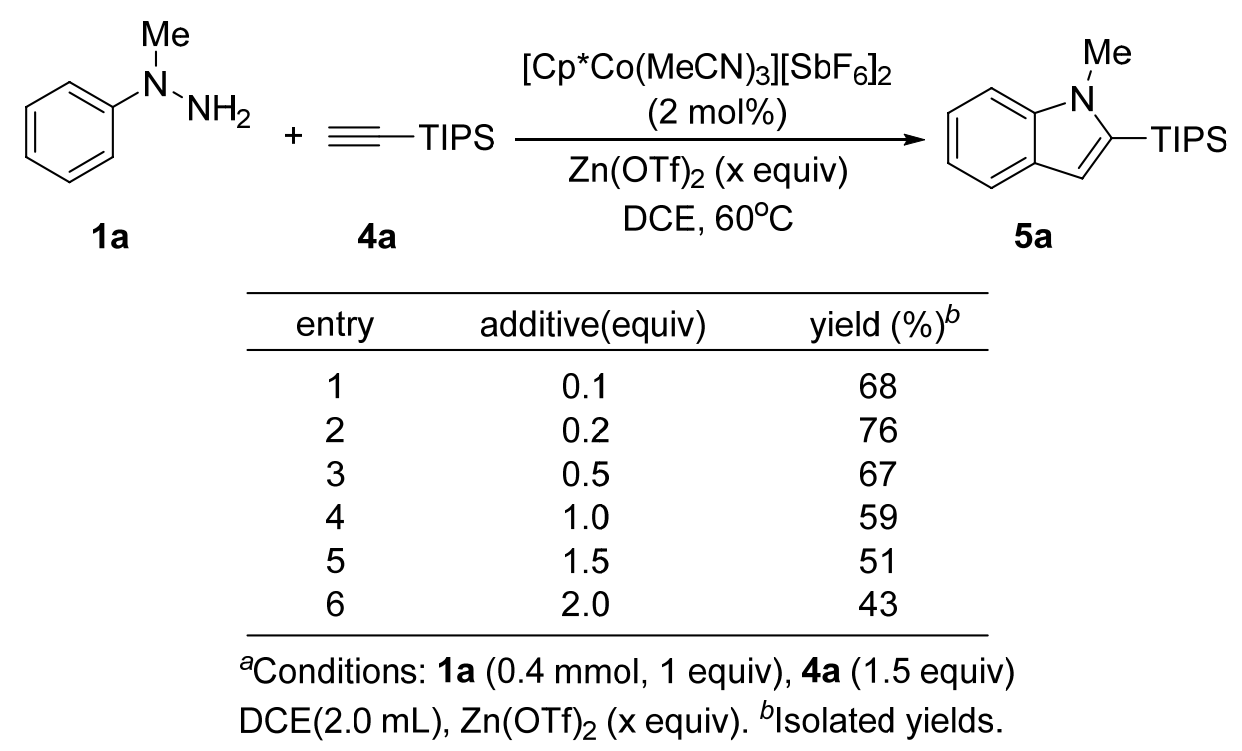

To a $13 \times 150 \mathrm{~mm}$ test tube equipped with magnetic stir bar was added different equivalents of additive as follows: $\mathrm{Zn}(\mathrm{OTf})_{2}\left(15 \mathrm{mg}, 0.04 \mathrm{mmol}, 0.1\right.$ equiv), $\mathrm{Zn}(\mathrm{OTf})_{2}$ (29 mg, $0.08 \mathrm{mmol}, 0.2$ equiv), $\mathrm{Zn}(\mathrm{OTf})_{2}$ (72 mg, $0.2 \mathrm{mmol}, 0.5$ equiv), $\mathrm{Zn}(\mathrm{OTf})_{2}$ (145 mg, $0.4 \mathrm{mmol}, 1.0$ equiv), $\mathrm{Zn}(\mathrm{OTf})_{2}(217 \mathrm{mg}, 0.6 \mathrm{mmol}, 1.5$ equiv) and $\mathrm{Zn}(\mathrm{OTf})_{2}(290 \mathrm{mg}, 0.8 \mathrm{mmol}, 2.0$ equiv), respectively. The test tube was transferred to a glovebox, and then $\left[\mathrm{Cp} * \mathrm{Co}\left(\mathrm{CH}_{3} \mathrm{CN}\right)_{3}\right]\left[\mathrm{SbF}_{6}\right]_{2}(6.3 \mathrm{mg}, 0.008 \mathrm{mmol}, 2 \mathrm{~mol} \%)$ was further added. The test tube was sealed with a rubber septum and removed from the glovebox. A solution of $1 \mathbf{a}(48.9 \mathrm{mg}, 0.40 \mathrm{mmol}, 1.0$ equiv) and $4 \mathbf{a}$ (109.2 $\mathrm{mg}, 0.60$ mmol, 1.5 equiv) in $2.0 \mathrm{~mL}$ of DCE was injected into the test tube via syringe. The reaction mixture was stirred for $12 \mathrm{~h}$ at $60{ }^{\circ} \mathrm{C}$, during which time a constant checking by TLC was performed. The reaction mixture was cooled to room temperature and filtered over celite. The solvent was then removed under reduced pressure and the residue was purified by flash column chromatography on silica gel with 100:1 
hexanes/EtOAc as the eluent.

Table S7. Selected observations from initial screening of temperature. ${ }^{a, b}$

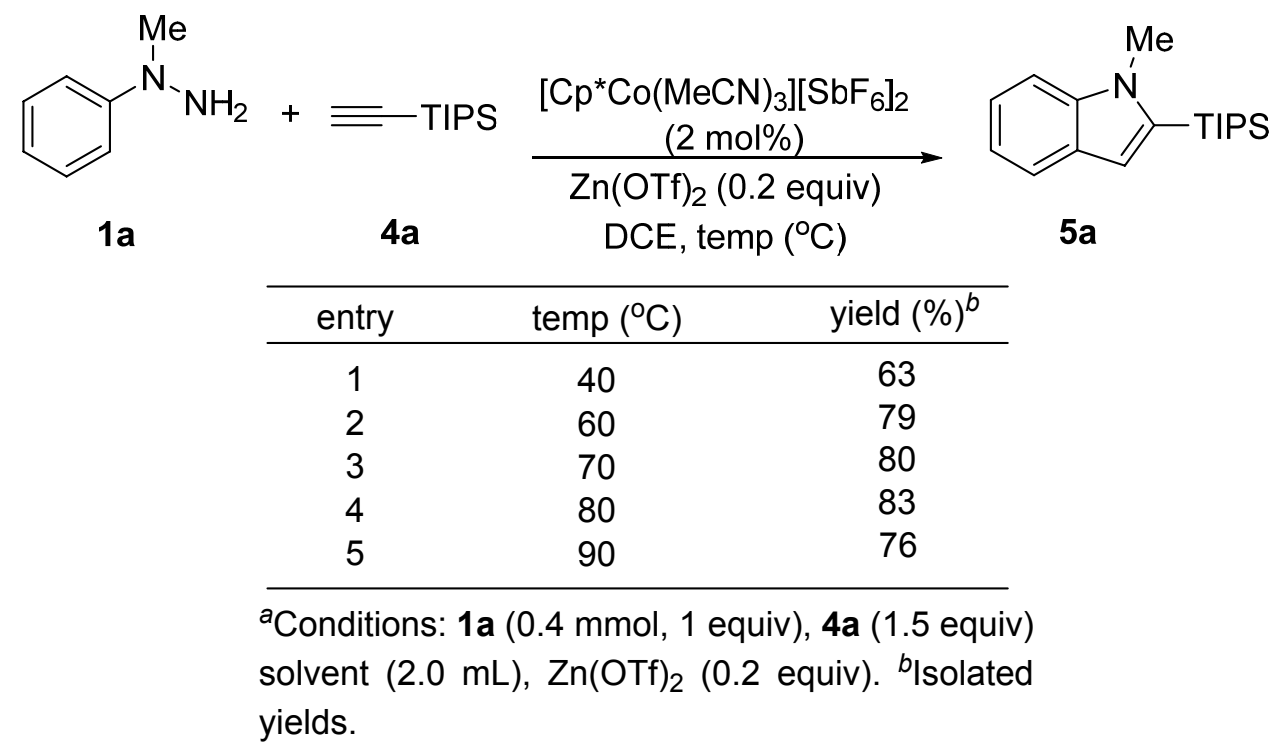

To a $13 \times 150 \mathrm{~mm}$ test tube equipped with magnetic stir bar was added $\mathrm{Zn}(\mathrm{OTf})_{2}$ (29 $\mathrm{mg}, 0.08 \mathrm{mmol}, 0.2$ equiv). The test tube was transferred to a glovebox, and then $\left[\mathrm{Cp} * \mathrm{Co}\left(\mathrm{CH}_{3} \mathrm{CN}\right)_{3}\right]\left[\mathrm{SbF}_{6}\right]_{2}(6.3 \mathrm{mg}, 0.008 \mathrm{mmol}, 2 \mathrm{~mol} \%)$ was further added. The test tube was sealed with a rubber septum and removed from the glovebox. A solution of $1 \mathrm{a}$ (48.9 mg, $0.40 \mathrm{mmol}, 1.0$ equiv) and 4a (109.2 mg, $0.60 \mathrm{mmol}, 1.5$ equiv) in 2.0 $\mathrm{mL}$ of DCE was injected into the test tube via syringe. The reaction mixture was stirred for $12 \mathrm{~h}$ at different temperature as follows: $40{ }^{\circ} \mathrm{C}, 60{ }^{\circ} \mathrm{C}, 70{ }^{\circ} \mathrm{C}, 80{ }^{\circ} \mathrm{C}$ and 90 ${ }^{\circ} \mathrm{C}$, repectively, during which time a constant checking by TLC was performed. The reaction mixture was cooled to room temperature and filtered over celite. The solvent was then removed under reduced pressure and the residue was purified by flash column chromatography on silica gel with 100:1 hexanes/EtOAc as the eluent.

Table S8. Selected observations from initial screening of additive. ${ }^{a, b}$

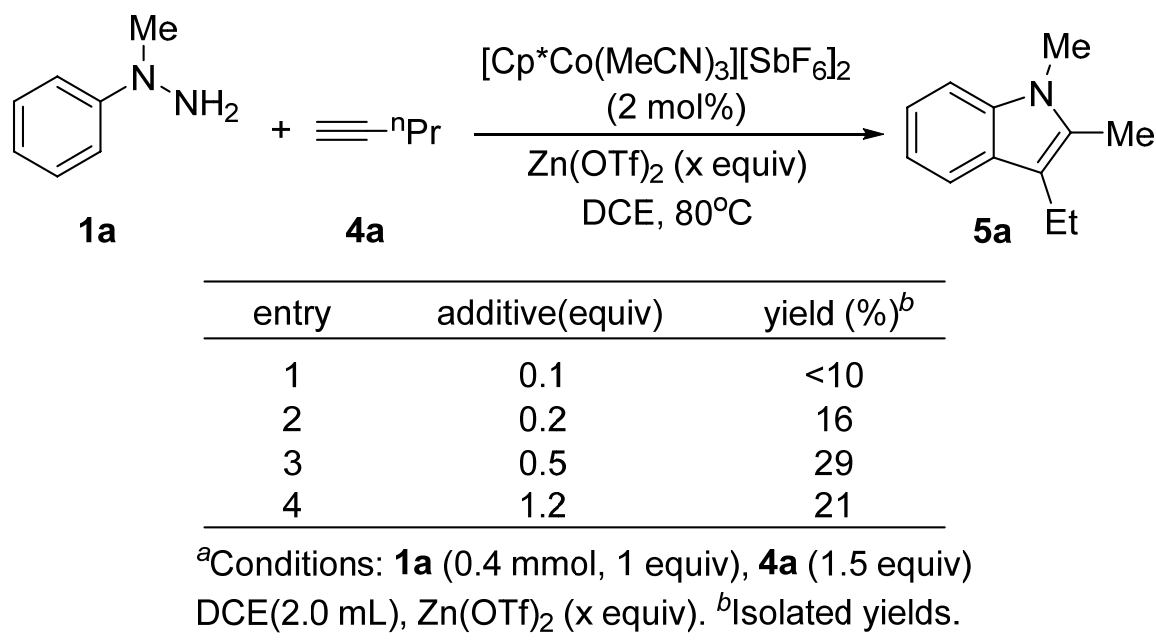

To a $13 \times 150 \mathrm{~mm}$ test tube equipped with magnetic stir bar was added different 
equivalents of additive as follows: $\mathrm{Zn}(\mathrm{OTf})_{2}(14.5 \mathrm{mg}, 0.04 \mathrm{mmol}, 0.1$ equiv), $\mathrm{Zn}(\mathrm{OTf})_{2}\left(29 \mathrm{mg}, 0.08 \mathrm{mmol}, 0.2\right.$ equiv), $\mathrm{Zn}(\mathrm{OTf})_{2}(72 \mathrm{mg}, 0.2 \mathrm{mmol}, 0.5$ equiv) and $\mathrm{Zn}(\mathrm{OTf})_{2}(174 \mathrm{mg}, 0.48 \mathrm{mmol}, 1.2$ equiv $)$, respectively. The test tube was transferred to a glovebox, and then $\left[\mathrm{Cp} * \mathrm{Co}\left(\mathrm{CH}_{3} \mathrm{CN}\right)_{3}\right]\left[\mathrm{SbF}_{6}\right]_{2}(6.3 \mathrm{mg}, 0.008 \mathrm{mmol}, 2 \mathrm{~mol} \%)$ was further added. The test tube was sealed with a rubber septum and removed from the glovebox. A solution of $\mathbf{1 a}$ ( $48.9 \mathrm{mg}, 0.40 \mathrm{mmol}, 1.0$ equiv), $4 \mathbf{a}$ ( $40.8 \mathrm{mg}, 0.60$ mmol, 1.5 equiv) in $2.0 \mathrm{~mL}$ of DCE was injected into the test tube via syringe. The reaction mixture was stirred for $12 \mathrm{~h}$ at $80{ }^{\circ} \mathrm{C}$, during which time a constant checking by TLC was performed. The reaction mixture was cooled to room temperature and filtered over celite. The solvent was then removed under reduced pressure and the residue was purified by flash column chromatography on silica gel with 100:1 hexanes/EtOAc as the eluent.

\subsection{The control experiments testing the additives and catalyst.}

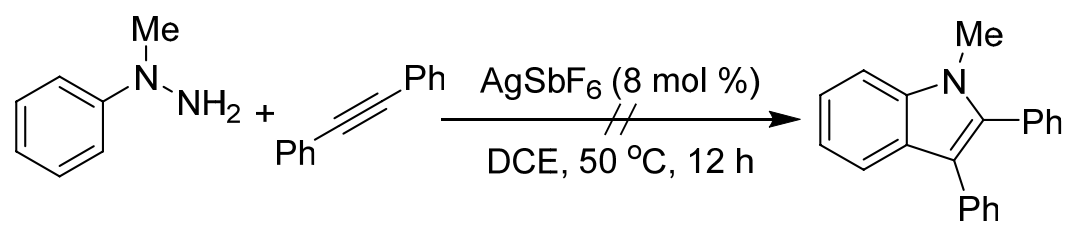

To a $13 \times 150 \mathrm{~mm}$ test tube equipped with magnetic stir bar was added $\mathbf{2 a}$ (106.5 $\mathrm{mg}, 0.60 \mathrm{mmol}, 1.5$ equiv). The test tube was transferred to a glovebox, and then $\mathrm{AgSbF}_{6}(11 \mathrm{mg}, 0.032 \mathrm{mmol}, 8 \mathrm{~mol} \%$ ) was further added. The test tube was sealed with a rubber septum and removed from the glovebox. A solution of $1 \mathrm{a}(48.9 \mathrm{mg}, 0.40$ mmol, 1.0 equiv) in $2.0 \mathrm{~mL}$ of DCE was injected into the test tube via syringe. The reaction mixture was stirred for $12 \mathrm{~h}$ at $50{ }^{\circ} \mathrm{C}$, during which time a constant checking by TLC was performed. And no reaction was observed.

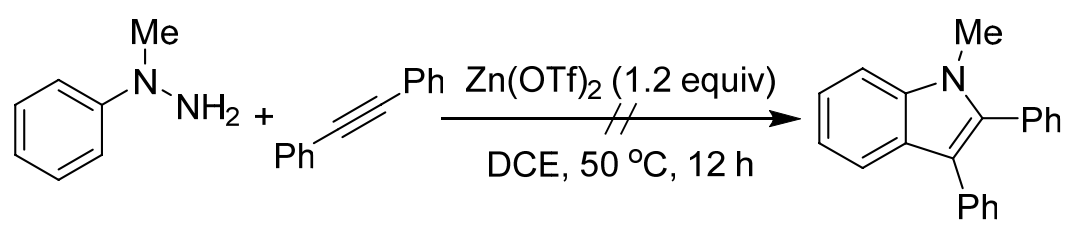

To a $13 \times 150 \mathrm{~mm}$ test tube equipped with magnetic stir bar were added $\mathrm{Zn}(\mathrm{OTf})_{2}$ (174 mg, $0.48 \mathrm{mmol}, 1.2$ equiv) and $2 \mathrm{a}$ (106.5 mg, $0.60 \mathrm{mmol}, 1.5$ equiv). The test tube was transferred to a glovebox, and then the test tube was sealed with a rubber septum and removed from the glovebox. A solution of $1 \mathrm{a}(48.9 \mathrm{mg}, 0.40 \mathrm{mmol}, 1.0$ equiv) in $2.0 \mathrm{~mL}$ of DCE was injected into the test tube via syringe. The reaction mixture was stirred for $12 \mathrm{~h}$ at $50{ }^{\circ} \mathrm{C}$, during which time a constant checking by TLC was performed. And no reaction was observed.

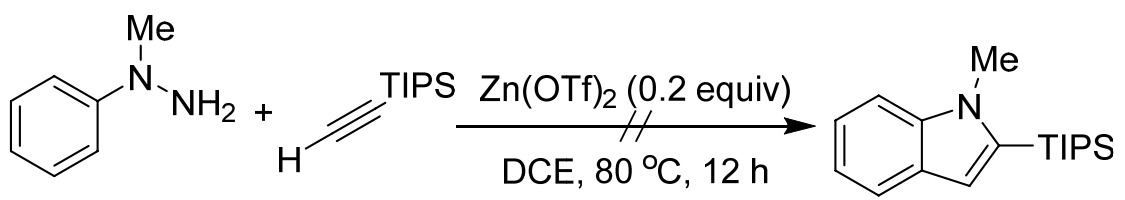

To a $13 \times 150 \mathrm{~mm}$ test tube equipped with magnetic stir bar was added $\mathrm{Zn}(\mathrm{OTf})_{2}$ 
(29 mg, $0.08 \mathrm{mmol}, 0.2$ equiv). The test tube was transferred to a glovebox, and then the test tube was sealed with a rubber septum and removed from the glovebox. A solution of 1a (48.9 mg, $0.40 \mathrm{mmol}, 1.0$ equiv) and $4 \mathbf{a}(109.2 \mathrm{mg}, 0.60 \mathrm{mmol}, 1.5$ equiv) in $2.0 \mathrm{~mL}$ of DCE was injected into the test tube via syringe. The reaction mixture was stirred for $12 \mathrm{~h}$ at $80{ }^{\circ} \mathrm{C}$ during which time a constant checking by TLC was performed. And no reaction was observed.

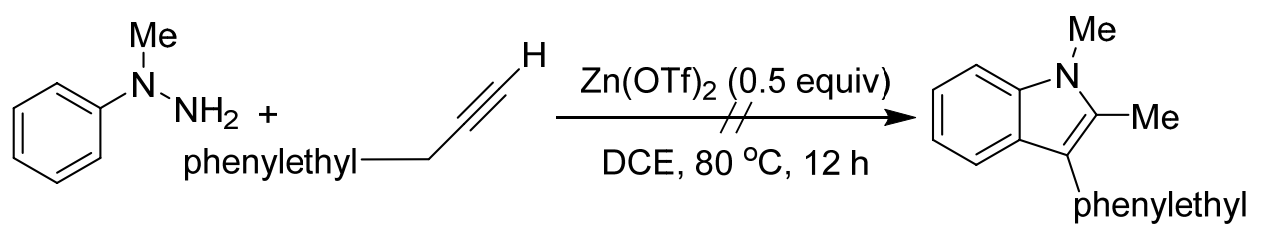

To a $13 \times 150 \mathrm{~mm}$ test tube equipped with magnetic stir bar was added $\mathrm{Zn}(\mathrm{OTf})_{2}$ ( $72 \mathrm{mg}, 0.2 \mathrm{mmol}, 0.5$ equiv). The test tube was transferred to a glovebox, and then the test tube was sealed with a rubber septum and removed from the glovebox. A solution of $1 \mathrm{a}$ ( $48.9 \mathrm{mg}, 0.40 \mathrm{mmol}, 1.0$ equiv), $4 \mathbf{n}$ ( $86.5 \mathrm{mg}, 0.60 \mathrm{mmol}, 1.5$ equiv) in $2.0 \mathrm{~mL}$ of DCE was injected into the test tube via syringe. The reaction mixture was stirred for $12 \mathrm{~h}$ at $80{ }^{\circ} \mathrm{C}$, during which time a constant checking by TLC was performed. And no reaction was observed.

\section{Competition Experiment}

\section{Determination of electronic effect on the alkyne reaction:}

To a $13 \times 150 \mathrm{~mm}$ test tube equipped with magnetic stir bar were added $\mathbf{1 n}$ (76 $\mathrm{mg}, 0.50 \mathrm{mmol}, 1$ equiv), $\mathbf{1 r}(90 \mathrm{mg}, 0.50 \mathrm{mmol}, 1$ equiv) and $\mathbf{2 a}(89 \mathrm{mg}, 0.50 \mathrm{mmol}$, 1 equiv) and $\mathrm{Zn}(\mathrm{OTf})_{2}(217 \mathrm{mg}, 0.6 \mathrm{mmol}, 1.2$ equiv). The test tube was transferred to a glovebox, and then $\left[\mathrm{Cp}^{*} \mathrm{CoI}_{2}\right]_{2}(8.96 \mathrm{mg}, 0.010 \mathrm{mmol}, 2 \mathrm{~mol} \%)$ and $\mathrm{AgSbF}_{6}(13.74$ $\mathrm{mg}, 0.040 \mathrm{mmol}, 8 \mathrm{~mol} \%$ ) were further added. The test tube was sealed with a rubber septum, covered with tin foil, and removed from the glovebox. Then the test tube was injected $2 \mathrm{~mL}$ of DCE via syringe. The reaction mixture was stirred for $12 \mathrm{~h}$ at $50{ }^{\circ} \mathrm{C}$. The reaction mixture was directly subjected to ${ }^{1} \mathrm{H}$ NMR 3n (33\% yield) and $3 \mathbf{r}(60 \%$ yield). 
<smiles></smiles>

${ }^{1} \mathrm{H} \mathrm{NMR}\left(400 \mathrm{MHz}, \mathrm{CDCl}_{3}\right)$<smiles>COc1ccc2c(c1)c(-c1ccccc1)c(-c1ccccc1)n2C</smiles><smiles>COC(=O)c1ccc2c(c1)c(-c1ccccc1)c(-c1ccccc1)n2C</smiles>

$\mathrm{N}-\mathrm{CH}_{3}$

is

$$
\text { COOMe }
$$

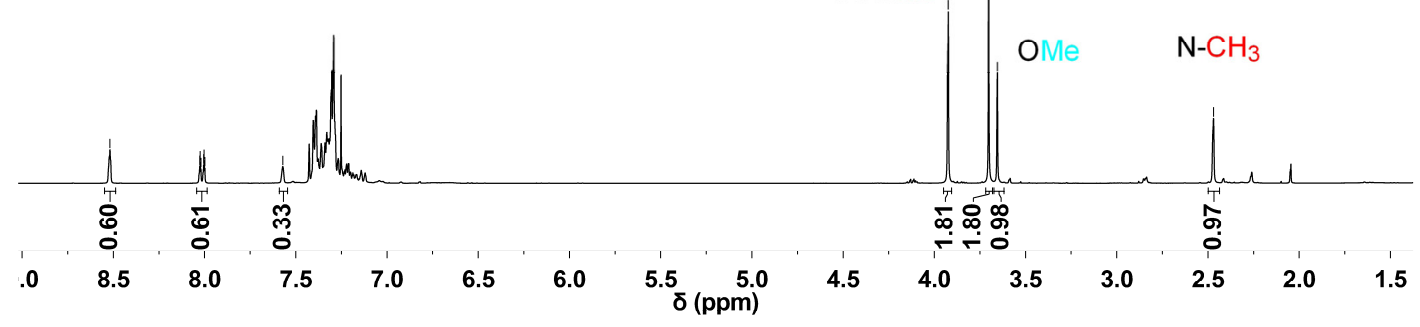

Figure S1. ${ }^{1}$ H NMR spectrum for the mixture of products from the equation above.

\section{Kinetic Isotope Effect Experiments}

\section{Preparation of deuterated 1-methyl-1-phenylhydrazine substrate:}<smiles>[2H]c1cc([2H])c(NC([2H])([O-])[O-])c([2H])c1</smiles>

$N$-Methyl-[2,4,6-trisdeutero]-aniline: The title compound was synthesized according to a literature-reported procedure. A solution containing $\mathrm{N}$-methylanilinium hydrochloride $(4.28 \mathrm{~g}, 0.03 \mathrm{~mol})$ and $\mathrm{D}_{2} \mathrm{O}(4 \mathrm{~mL}, 0.2 \mathrm{~mol})$ was allowed to reflux for $24 \mathrm{~h}$ and then the solvent was removed under reduced pressure. The procedure was repeated for additional 5 times. The solution was neutralized with $\mathrm{NaOH}$ solution and extracted with $\mathrm{CH}_{2} \mathrm{Cl}_{2}$. The organic phase was dried over $\mathrm{Na}_{2} \mathrm{SO}_{4}$, filtered and the solvent was removed under reduced pressure. The title compound was obtained as a dark brown liquid in $91 \%$ yield by vacuum distillation. $\mathbf{R}_{\mathbf{f}}=0.55$ (PE:EtOAc, 10:1). ${ }^{1} \mathbf{H}$ NMR 
(400 MHz, $\left.\mathbf{C D C l}_{3}\right) \delta 7.24(\mathrm{~s}, 2 \mathrm{H}), 3.67(\mathrm{~s}, 1 \mathrm{H}), 2.86(\mathrm{~d}, J=1.0 \mathrm{~Hz}, 3 \mathrm{H}) .{ }^{13} \mathbf{C} \mathbf{N M R}$ (101 MHz, $\left.\mathbf{C D C l}_{3}\right) \delta 149.32,129.13,117.16(\mathrm{t}, J=24.24 \mathrm{~Hz}), 112.33(\mathrm{t}, J=24.24$ $\mathrm{Hz}), 112.57,112.33,112.10,30.90$.<smiles>[2H]c1cc([2H])c(N(C)N)c([2H])c1</smiles>

$N$-Methyl- $N$-[2,4,6-trisdeutero]-phenylhydrazine $\quad\left(1 \mathrm{a}-d_{3}\right): \quad$ A mixture of aniline (for example, $N$-methyl-[2,4,6-trisdeutero] -aniline, $2.70 \mathrm{~g}, 0.025 \mathrm{~mol})$, concentrated $\mathrm{HCl}(3.65 \mathrm{~mL}, 0.12$ $\mathrm{mol})$, and ice (10 g) was placed in a round-bottom flask equipped with a magnetic stir bar. The mixture was stirred vigorously, and the temperature was maintained at $10{ }^{\circ} \mathrm{C}$ or below by the addition of additional ice as required. To this mixture was added an aqueous solution $(7 \mathrm{~mL})$ of $\mathrm{NaNO}_{2}(1.75 \mathrm{~g}, 0.025 \mathrm{~mol})$ over the course of 5 to $10 \mathrm{~min}$. The reaction was allowed to proceed for at least $1 \mathrm{~h}$, during which time a constant checking by TLC was performed. Once the reaction proceeded to a desired degree, the $\mathrm{NH}_{4} \mathrm{Cl}(1.61 \mathrm{~g}, 0.03 \mathrm{~mol})$ was added to reaction mixture. $\mathrm{Zn}$ powder $(3.27 \mathrm{~g}, 0.05 \mathrm{~mol})$ was added via powder funnel in portions over 30 min with vigorous stirring. Upon addition of the $\mathrm{Zn}$ powder, the solution was stirred for an additional $4 \mathrm{~h}$ at $45{ }^{\circ} \mathrm{C}$. After completion of the reaction as monitored by TLC, the solution was allowed cooled to room temperature. All precipitate was filtered and the remaining mixture was then extracted with $\mathrm{CH}_{2} \mathrm{Cl}_{2}$. The organic phase was washed with saturated brine solution, dried over $\mathrm{MgSO}_{4}$, filtered, and the solvent was removed under reduced pressure. The product was separated on a flash column (petroleum ether/ ethyl acetate 6:1).The title compound was obtained as yellow liquid 82\% yield. $\mathbf{R}_{\mathbf{f}}=0.40$ (PE:EtOAc, 6:1). ${ }^{1} \mathbf{H}$ NMR (400 MHz, $\left.\mathbf{C D C l}_{3}\right) \delta 7.28(\mathrm{~s}, 2 \mathrm{H})$, 3.62 (s, 2H), $3.12(\mathrm{~s}, 3 \mathrm{H}) .{ }^{13} \mathbf{C}$ NMR (101 MHz, $\left.\mathbf{C D C l}_{3}\right) \delta 152.61,128.73,118.24(\mathrm{t}$, $J=24.24 \mathrm{~Hz}), 113.22(\mathrm{t}, J=24.24 \mathrm{~Hz}), 44.43$.

\section{Determination of intermolecular kinetic isotope effect for 1, 2-diphenylethyne:}

To a $13 \times 150 \mathrm{~mm}$ test tube equipped with magnetic stir bar was added $\mathbf{2 a}$ ( 89 $\mathrm{mg}, 0.50 \mathrm{mmol}, 1.0$ equiv). The test tube was transferred to a glovebox, and then $\left[\mathrm{Cp}^{*} \mathrm{CoI}_{2}\right]_{2}(6.2 \mathrm{mg}, 0.010 \mathrm{mmol}, 2 \mathrm{~mol} \%)$ and $\mathrm{AgSbF}_{6}(13.7 \mathrm{mg}, 0.040 \mathrm{mmol}, 8$ $\mathrm{mol} \%)$ and $\mathrm{Zn}(\mathrm{OTf})_{2}(217.2 \mathrm{mg}, 0.60 \mathrm{mmol}, 1.2$ equiv) were further added. The test tube was sealed with a rubber septum and removed from the glovebox. A DCE $(2 \mathrm{~mL})$ solution of $1 \mathbf{a}\left(61 \mathrm{mg}, 0.50 \mathrm{mmol}, 1.0\right.$ equiv) and $\mathbf{1 a}-d_{3}(62.5 \mathrm{mg}, 0.50 \mathrm{mmol}, 1.0$ equiv) was injected into the test tube via syringe. The reaction was allowed to proceed at $50{ }^{\circ} \mathrm{C}$ for 1 hour. The product was purified by silica gel flash chromatography (hexanes:EtOAc, 50:1) as a white solid. The product ratio was determined by ${ }^{1} \mathrm{H}$ $\mathrm{NMR}\left(400 \mathrm{MHz}, \mathrm{CDCl}_{3}\right)$. 
<smiles>CN(N)c1ccccc1</smiles>

1a<smiles>[2H]c1cc([2H])c(N(C)N)c([18OH])c1</smiles>

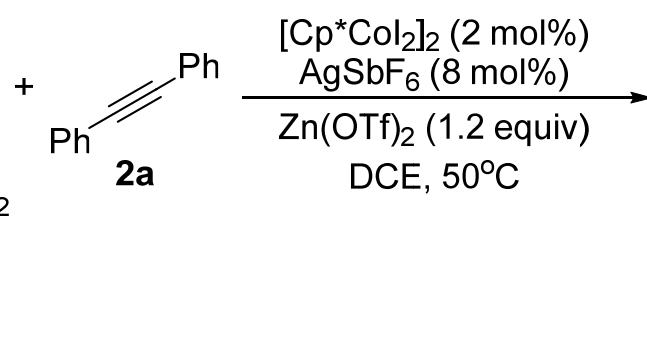

$k_{H} / k_{D}=0.72 /(1-0.72)=2.57$<smiles>Cn1c(-c2ccccc2)c(-c2ccccc2)c2cc(I)ccc21</smiles>

3a $\mathrm{Ph}$<smiles>[2H]c1cc([2H])c2c(c1)c(-c1ccccc1)c(-c1ccccc1)n2C</smiles>

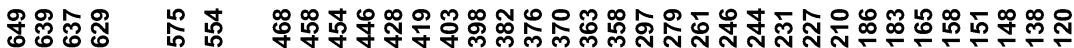

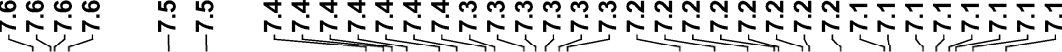

${ }^{1} \mathrm{H} \mathrm{NMR}\left(400 \mathrm{MHz}, \mathrm{CDCl}_{3}\right)$<smiles>C[N+]1(c2ccccc2)c2ccccc2-c2ccccc21</smiles><smiles>[2H]c1cc(C)cc2c(-c3ccccc3)c(-c3ccccc3)n(C)c12</smiles>

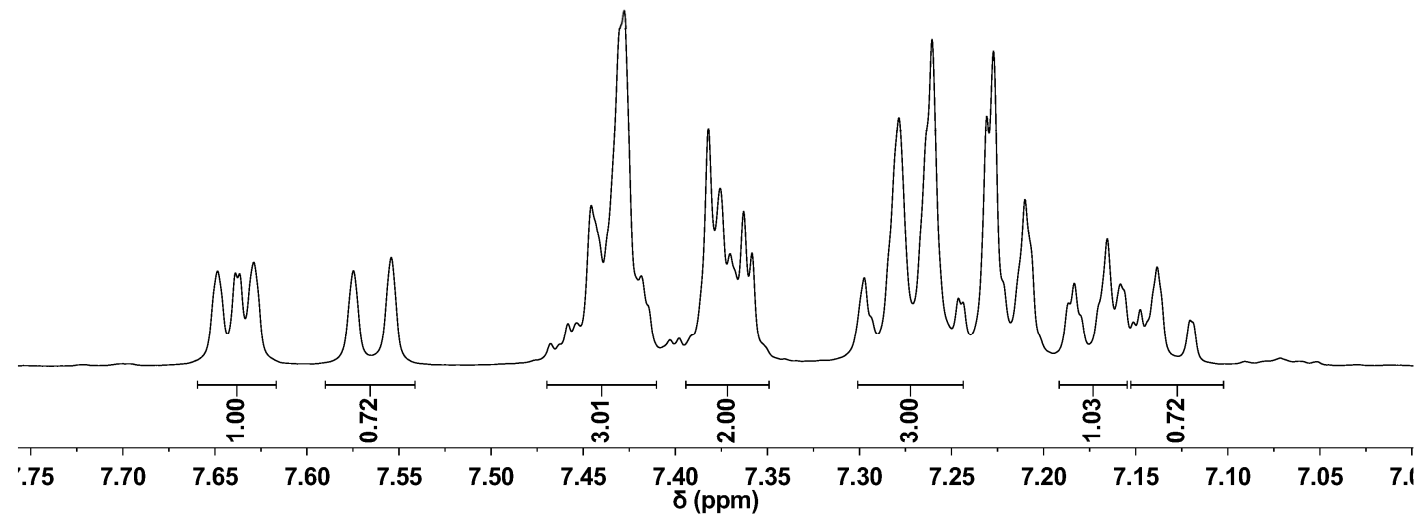

Figure S2. ${ }^{1}$ H NMR spectrum for the mixture of products from the equation above.

Determination of intermolecular kinetic isotope effect for ethynyltriisopropyl -silane:

A $13 \times 150 \mathrm{~mm}$ test tube equipped with magnetic stir bar was transferred to a glovebox, and then $\left[\mathrm{Cp}^{*} \mathrm{Co}\left(\mathrm{CH}_{3} \mathrm{CN}\right)_{3}\right]\left[\mathrm{SbF}_{6}\right]_{2}(6.3 \mathrm{mg}, 0.008 \mathrm{mmol}, 2 \mathrm{~mol} \%)$ and $\mathrm{Zn}(\mathrm{OTf})_{2}(36.2 \mathrm{mg}, 0.10 \mathrm{mmol}, 0.2$ equiv) were further added. The test tube was sealed with a rubber septum and removed from the glovebox. A DCE $(2 \mathrm{~mL})$ solution of $1 \mathbf{a}\left(61 \mathrm{mg}, 0.50 \mathrm{mmol}, 1.0\right.$ equiv), $1 \mathbf{a}-d_{3}(62.5 \mathrm{mg}, 0.50 \mathrm{mmol}, 1.0$ equiv) and $4 \mathbf{a}$ ( $89 \mathrm{mg}, 0.50 \mathrm{mmol}, 1.0$ equiv) was injected into the test tube via syringe. The reaction was allowed to proceed at $80{ }^{\circ} \mathrm{C}$ for $3 \mathrm{~h}$. The product was purified by silica gel flash chromatography (hexanes:EtOAc, 50:1) as a white solid. The product ratio was 
determined by ${ }^{1} \mathrm{H}$ NMR (400 MHz, $\mathrm{CDCl}_{3}$ ).<smiles>CN(N)c1ccccc1</smiles>

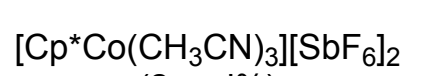

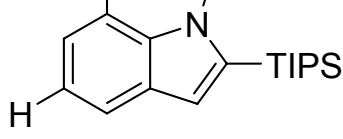

$1 \mathrm{a}$<smiles>[2H]c1cc([2H])c(N(C)N)c([18OH])c1</smiles><smiles>[2H]c1cc([2H])c2c(c1)cc([I-][Na])n2C</smiles>

$5 \mathrm{a}-d_{2}$

$k_{H} / k_{D}=0.76 /(1-0.76)=3.17$

${ }^{1} \mathrm{H} \mathrm{NMR}\left(400 \mathrm{MHz}, \mathrm{CDCl}_{3}\right)$<smiles></smiles><smiles>[2H]c1cc([2H])c2c(c1)cc(C(F)(F)F)n2C</smiles>

$5 a-d 2$

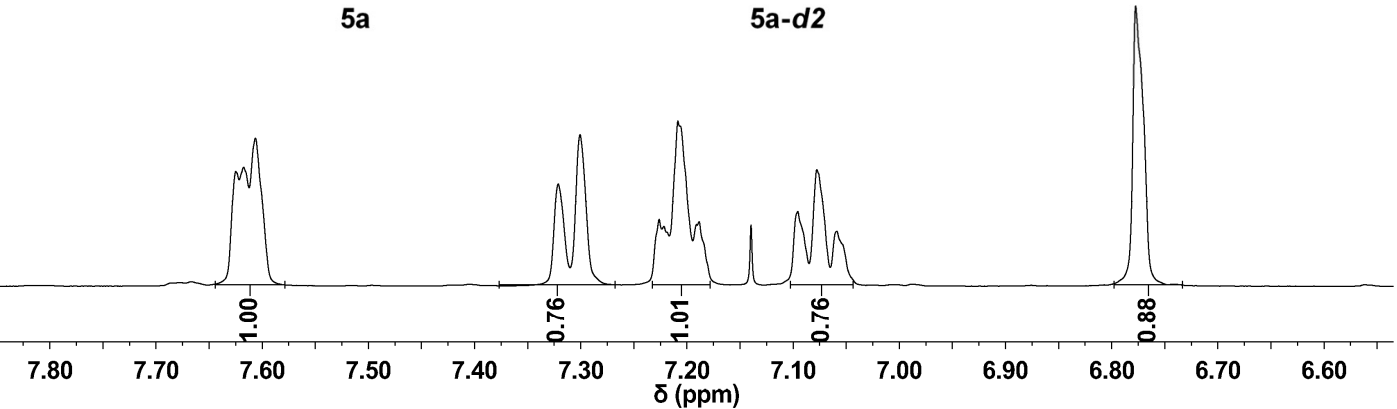

Figure S3. ${ }^{1}$ H NMR spectrum for the mixture of products from the equation above.

\section{Relationship between Alkyne and Allene in Catalytic Mechanism}

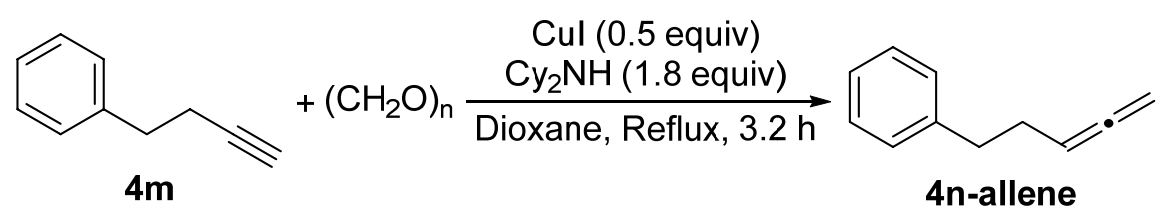

Using the procedure of $\mathrm{Ma}^{2}$ to a strirred solution of paraformaldehyde $(375 \mathrm{mg}$, $12.5 \mathrm{mmol}, 2.5$ equiv) and $\mathrm{CuI}(476 \mathrm{mg}, 2.5 \mathrm{mmol}, 0.5$ equiv) in dioxane (25 mL) were added but-3-yn-1-ylbenzene ( $5.0 \mathrm{mmol}, 1.0$ equiv) and diayalogexylamine (1.8 $\mathrm{mL}, 9.0 \mathrm{mmol}, 1.8$ equiv) under atmosphere of argon. The resulting mixture was then refluxed for $3.2 \mathrm{~h}$. After the reaction was complete as monitored by TCL, the mixture was then cooled to room temperture and filtered. The filtrate was concentrated under reduced pressure and then diluted with water and EA followed by the addition of $1 \mathrm{M}$ $\mathrm{HCl}$ until $\mathrm{pH}$ equals to 1-2. The resulting mixture was extracted three times with EA. The organic layer was then washed with brine and dried over $\mathrm{Na}_{2} \mathrm{SO}_{4}$, filtered, and the solvent was removed under reduced pressure. The residue was purified by flash 
chromatography with hexane to give corresponding product $\mathbf{5 n - a l l e n e ~ a s ~ c o l o r l e s s ~ o i l ~}$ liquid in $70 \%$ yield.

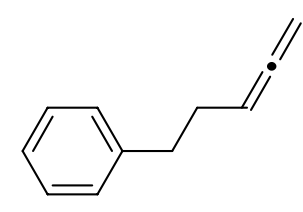

penta-3,4-dien-1-ylbenzene(5n-allene): The title compound was obtained as an oil liquid in $70 \%$ yield $(504.3 \mathrm{mg}) . \mathbf{R}_{\mathbf{f}}=0.40(\mathrm{PE})$. ${ }^{1} \mathbf{H}$ NMR (400 MHz, $\left.\mathbf{C D C l}_{3}\right) \delta 7.18(\mathrm{dd}, J=10.7,4.0 \mathrm{~Hz}, 2 \mathrm{H})$, $7.13-7.05(\mathrm{~m}, 3 \mathrm{H}), 5.19-4.91(\mathrm{~m}, 1 \mathrm{H}), 4.59(\mathrm{ddd}, J=6.4,5.1$, $3.1 \mathrm{~Hz}, 2 \mathrm{H}), 2.64(\mathrm{t}, J=7.8 \mathrm{~Hz}, 2 \mathrm{H}), 2.30-2.11(\mathrm{~m}, 2 \mathrm{H}) .{ }^{13} \mathbf{C}$ NMR (101 MHz, $\left.\mathbf{C D C l}_{3}\right) \delta 208.79,141.95,128.72,128.53,126.10,89.66,75.37,35.61,30.22$.<smiles>CN(N)c1ccccc1</smiles>

1a

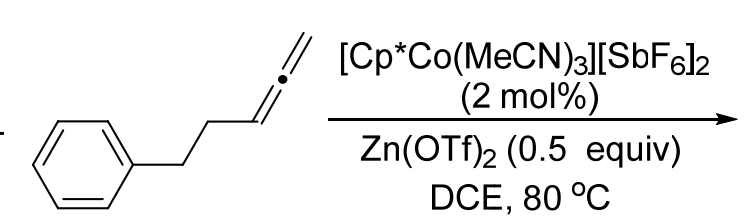

$4 n$-allene<smiles>Cc1c(CCc2ccccc2)c2ccccc2n1C</smiles>
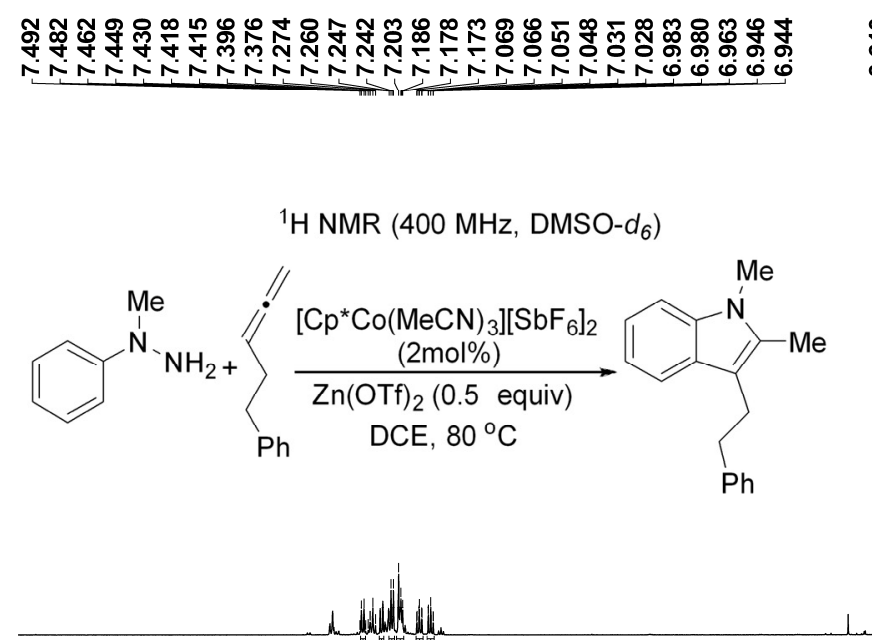

क ल

P.:

$\begin{array}{lllllll}9.5 & 9.0 & 8.5 & 8.0 & 7.5 & 7.0 & 6.5\end{array}$

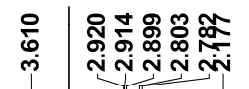

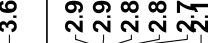

Figure S4. ${ }^{1} \mathrm{H}$ NMR spectrum for the mixture of products from the equation above. 


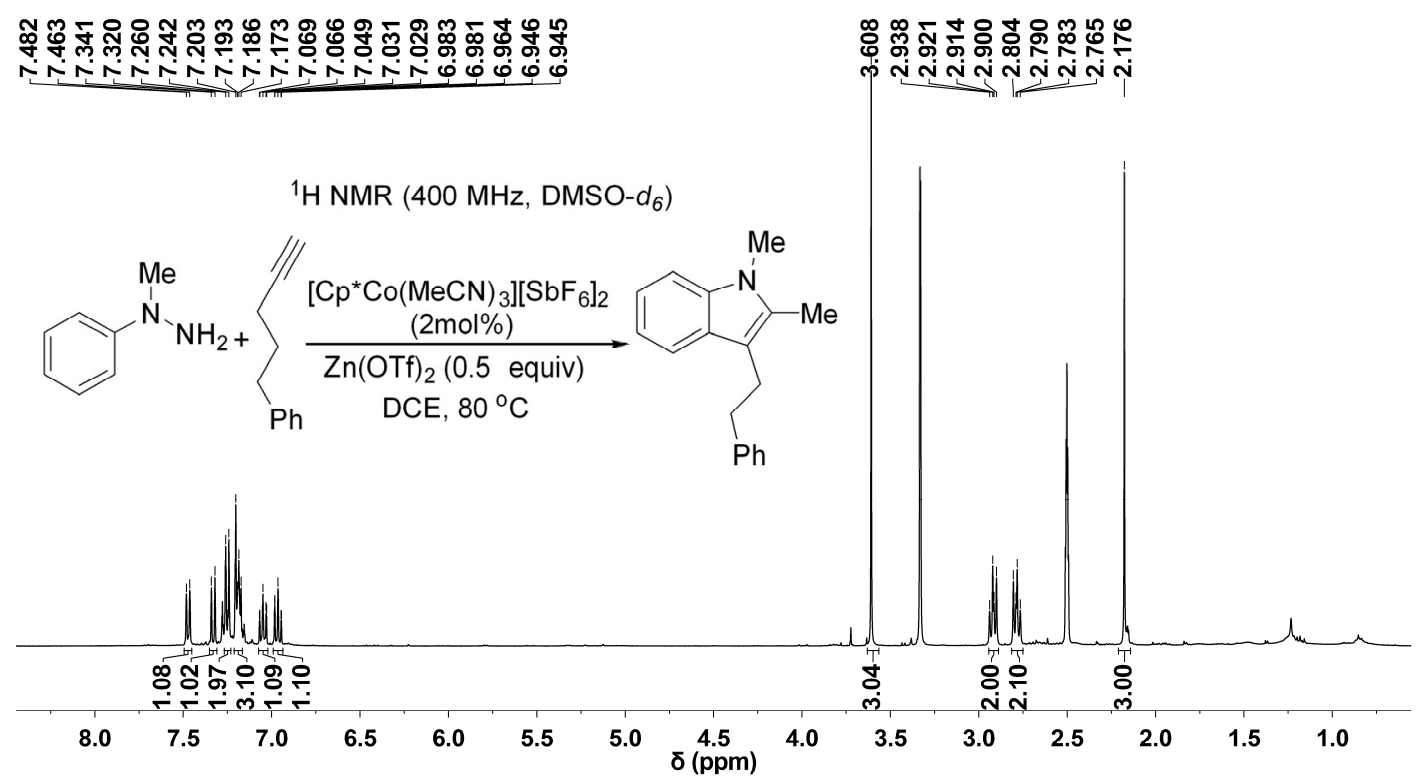

Figure S5. ${ }^{1}$ H NMR spectrum for the mixture of products from the equation above.

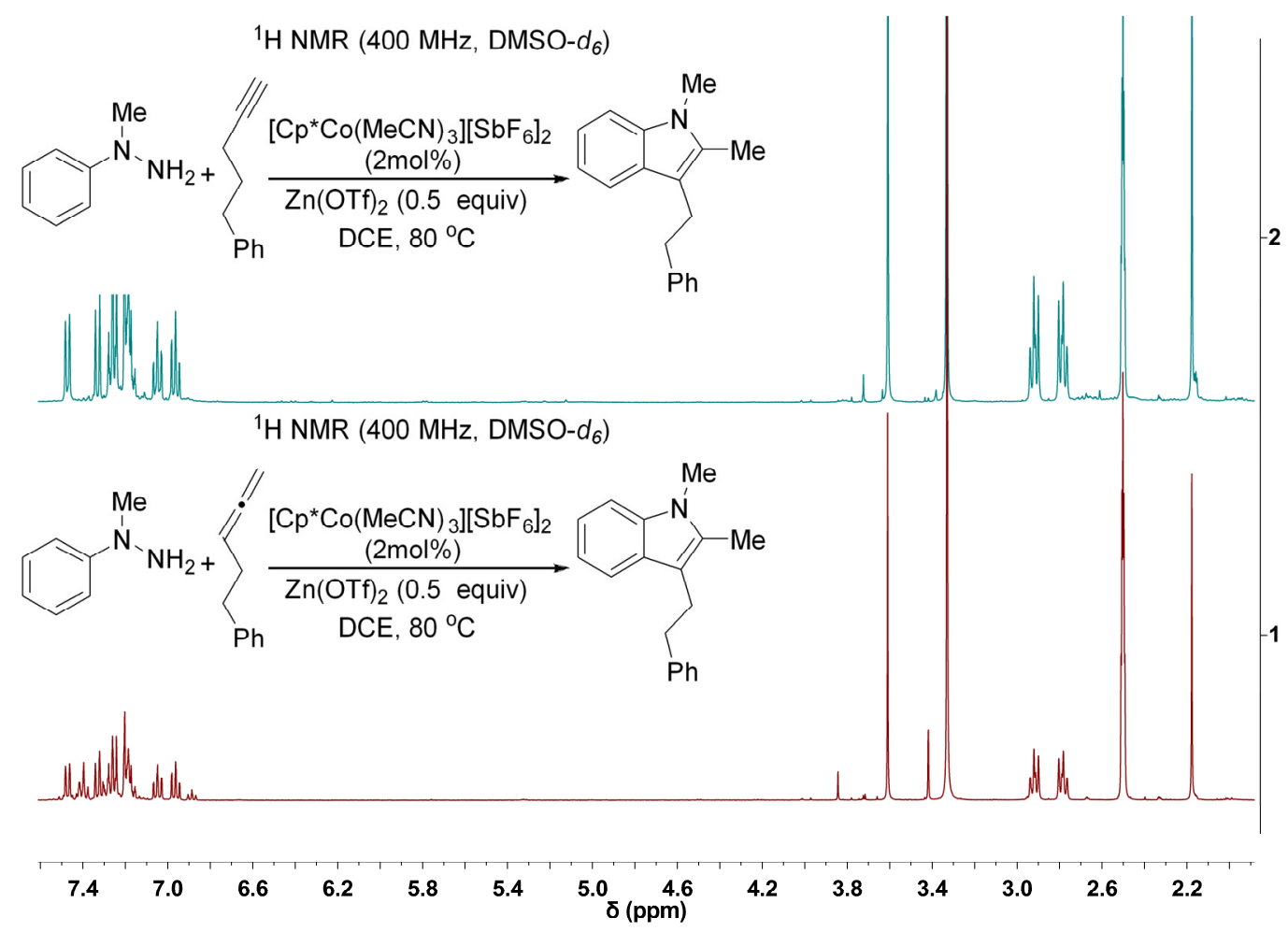

Figure S6. ${ }^{1}$ H NMR spectrum for the mixture of products from the equation above. 


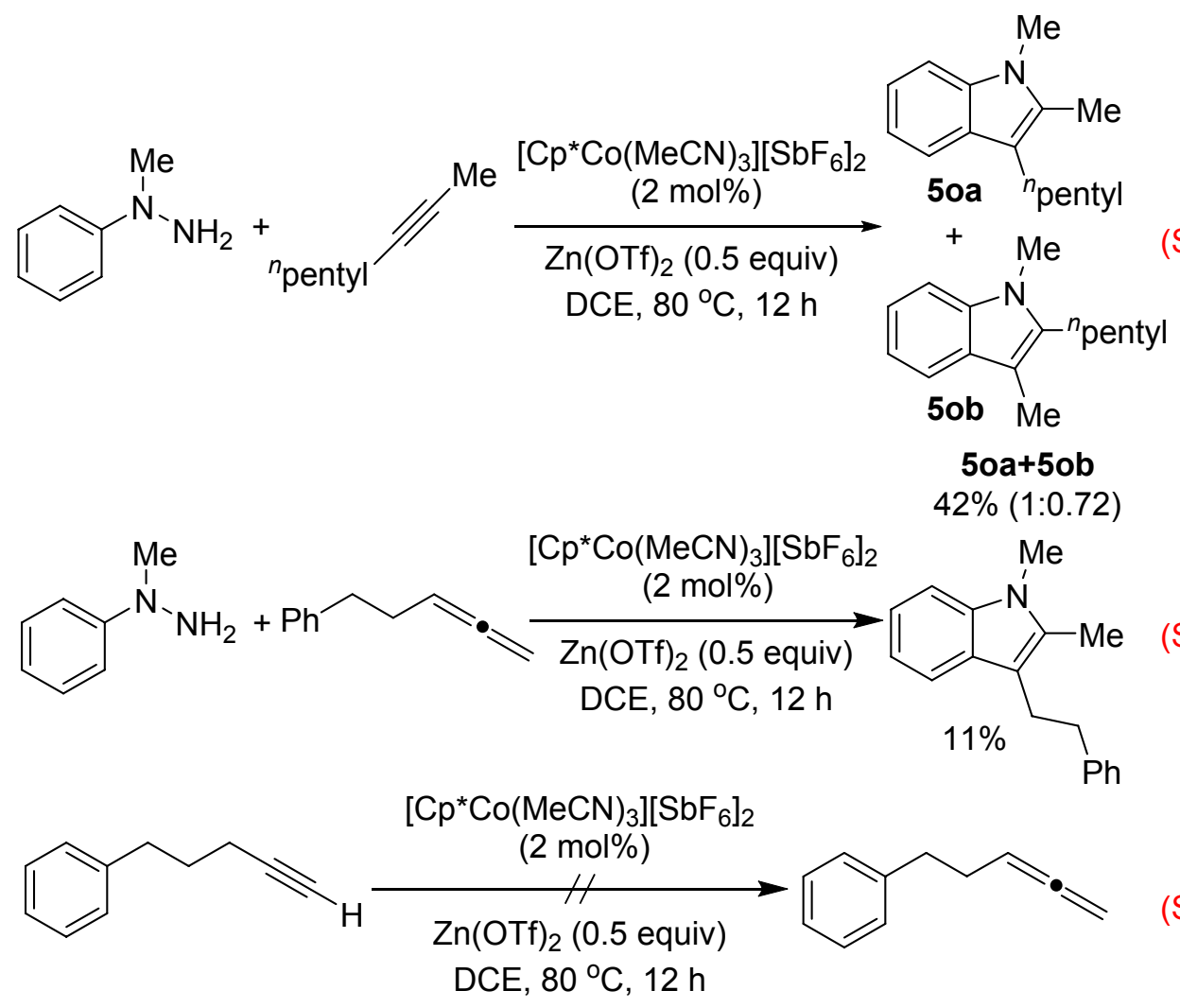

\section{Large Scale Synthesis of 3a}

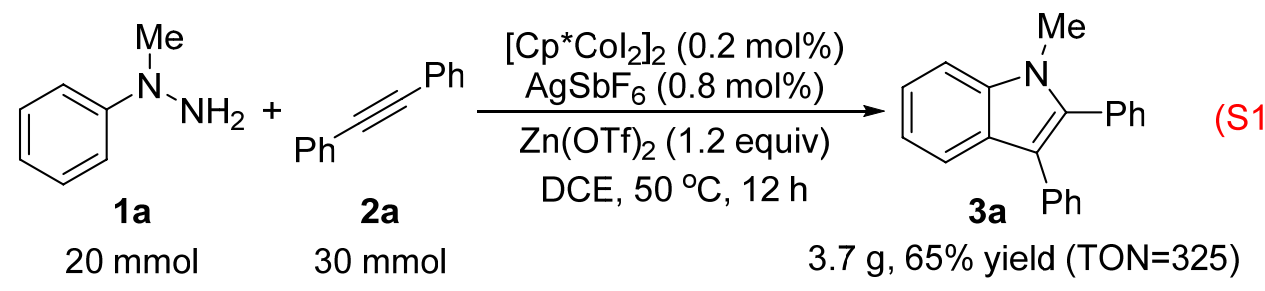

To a Schlenk flask (100 mL) equipped with magnetic stir bar was added 2a (5.34 g, $30 \mathrm{mmol}, 1.5$ equiv). The flask was transferred to a glovebox, then $\left[\mathrm{Cp}^{*} \mathrm{CoI}_{2}\right]_{2}$ (35.84 mg, $0.040 \mathrm{mmol}, 0.2 \mathrm{~mol} \%$ ), $\mathrm{AgSbF}_{6}(549.4 \mathrm{mg}, 0.160 \mathrm{mmol}, 0.8 \mathrm{~mol} \%$ ) and $\mathrm{Zn}(\mathrm{OTf})_{2}(8.7 \mathrm{~g}, 24 \mathrm{mmol}, 1.2$ equiv) were further added. The flask was sealed with a rubber septum and removed from the glovebox. A DCE $(30 \mathrm{~mL})$ solution of $\mathbf{1 a}(2.42$ $\mathrm{g}, 20 \mathrm{mmol}, 1.0$ equiv) was injected into the test tube via syringe. The reaction was allowed to proceed at $50{ }^{\circ} \mathrm{C}$ for $14 \mathrm{~h}$. The product was purified by silica gel flash chromatography (hexanes:EtOAc, 50:1) as a white solid for $3.7 \mathrm{~g}(65 \%)$. 


\section{Transformations of $5 \mathrm{a}$}

\section{Synthesis of $6 \mathrm{a}$}

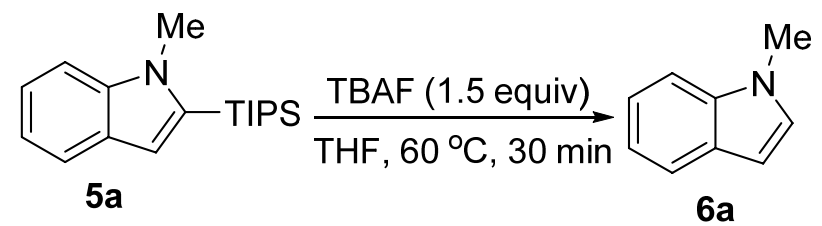

To a $13 \times 150 \mathrm{~mm}$ test tube equipped with magnetic stir bar were added 1-methyl-2-(triisopropylsilyl)-1H-indole (5a, $0.8 \mathrm{mmol}, 230 \mathrm{mg})$ in dry THF $(8 \mathrm{~mL})$ and tertabutylammonium fluoride hydrate (TBAF, $1 \mathrm{M}$ in THF, $1 \mathrm{~mL}$ ). The reaction mixture was stirred at $60{ }^{\circ} \mathrm{C}$ for $25 \mathrm{~min}$. Water $(10 \mathrm{~mL})$ was added and the mixture was extracted with EtOAc $(8 \mathrm{~mL} \times 3)$. The organic layer was combined, washed with brine and dried over anhydrous $\mathrm{Na}_{2} \mathrm{SO}_{4}$. The solvent was evaporated and the residue was purified by silica gel chromatography using PE to afford $6 \mathbf{a}(90 \mathrm{mg}, 86 \%)$ as an oil liquid.

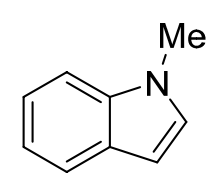

1-methyl-1H-indole (6a): The title compound was obtained as an oil liquid in $86 \%$ yield. $\mathbf{R}_{\mathbf{f}}=0.40$ (PE : EtOAc, $\left.80: 1\right)$. ${ }^{\mathbf{1}} \mathbf{H}$ NMR $(\mathbf{4 0 0} \mathbf{~ M H z}$, $\left.\mathbf{C D C l}_{3}\right) \delta 7.65(\mathrm{~d}, J=7.9 \mathrm{~Hz}, 1 \mathrm{H}), 7.34(\mathrm{~d}, J=8.2 \mathrm{~Hz}, 1 \mathrm{H}), 7.26-7.21$ $(\mathrm{m}, 1 \mathrm{H}), 7.12(\mathrm{t}, J=7.4 \mathrm{~Hz}, 1 \mathrm{H}), 7.06(\mathrm{~d}, J=3.1 \mathrm{~Hz}, 1 \mathrm{H}), 6.53-6.48$ $(\mathrm{m}, 1 \mathrm{H}), 3.80$ (s, 3H). ${ }^{13} \mathbf{C}$ NMR (101 MHz, $\left.\mathbf{C D C l}_{3}\right) \delta 135.62,127.73,127.40,120.42$, $119.81,118.20,108.12,99.82,31.77$.

\section{Synthesis of $7 \mathrm{a}$}

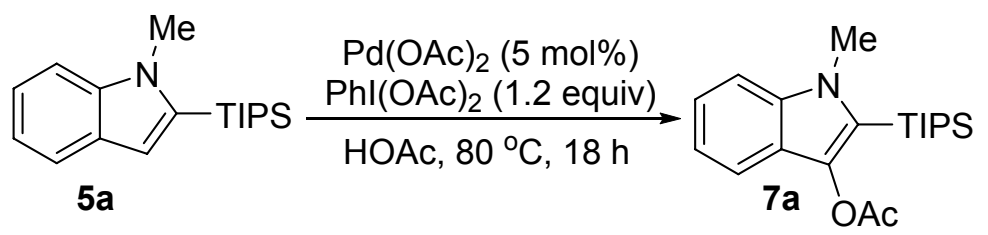

To a $13 \times 150 \mathrm{~mm}$ test tube equipped with magnetic stir bar were added 1-methyl-2-(triisopropylsilyl)-1H-indole (5a, $0.8 \mathrm{mmol}, 230 \mathrm{mg}), \operatorname{Pd}(\mathrm{OAc})_{2}(5 \mathrm{~mol} \%)$, $\mathrm{PhI}(\mathrm{OAc})_{2}(1.2$ equiv) and $\mathrm{HOAc}(4.0 \mathrm{~mL})$ as solvent. The reaction mixture was stirred at $80{ }^{\circ} \mathrm{C}$ for $18 \mathrm{~h}$ to afford $7 \mathbf{a}(218 \mathrm{mg}, 79 \%)$ as an oil liquid.<smiles></smiles>

1-methyl-2-(triisopropylsilyl)-1H-indol-3-yl acetate(7a): The title compound was obtained as an oil liquid in $79 \%$ yield. $\mathbf{R}_{\mathbf{f}}=$ 0.40 (PE : EtOAc, $80:$ 1). ${ }^{1} \mathbf{H}$ NMR (400 $\left.\mathbf{~ M H z , ~} \mathbf{C D C l}_{\mathbf{3}}\right) \delta 7.30$ $(\mathrm{dd}, J=7.8,5.7 \mathrm{~Hz}, 2 \mathrm{H}), 7.24-7.19(\mathrm{~m}, 1 \mathrm{H}), 7.07$ (dd, $J=11.0$, $4.0 \mathrm{~Hz}, 1 \mathrm{H}), 3.80$ (s, 3H), $2.33(\mathrm{~s}, 3 \mathrm{H}), 1.57$ (dq, $J=14.8,7.5 \mathrm{~Hz}$,

3H), 1.15 (d, $J=7.5 \mathrm{~Hz}, 18 \mathrm{H}) .{ }^{13} \mathbf{C}$ NMR (101 MHz, CDCl $) \delta 169.10,139.90$, 138.50, 124.86, 122.82, 120.64, 119.27, 118.25, 109.57, 33.62, 21.00, 18.91, 12.69 . HRMS (EI) Calcd. for $\mathrm{C}_{20} \mathrm{H}_{32} \mathrm{O}_{2} \mathrm{NSi}$ : [M] $]^{+}, 346.2197$. Found: $m / z .346 .2195$ 


\section{Synthesis of 8a}

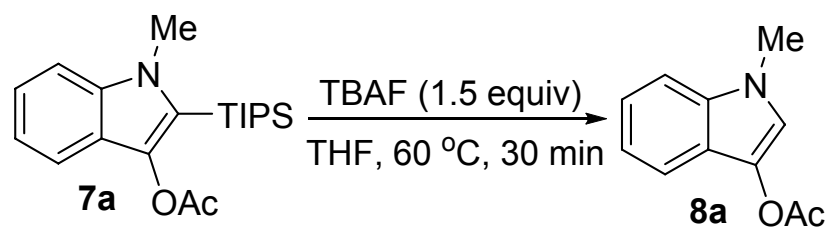

To a $13 \times 150 \mathrm{~mm}$ test tube equipped with magnetic stir bar were added 1-methyl-2-(triisopropylsilyl)-1H-indol-3-yl acetate (7a, $0.4 \mathrm{mmol}, 138.4 \mathrm{mg})$ in dry THF (4 mL) and tertabutylammonium fluoride hydrate (TBAF, $1 \mathrm{~mol} / \mathrm{L}$ in THF, 0.5 $\mathrm{mL})$. The reaction mixture was stirred at $60{ }^{\circ} \mathrm{C}$ for $30 \mathrm{~min}$. Water $(6 \mathrm{~mL})$ was added and the mixture was extracted with EtOAc $(5 \mathrm{~mL} \times 3)$. The organic layer was combined, washed with brine and dried over anhydrous $\mathrm{Na}_{2} \mathrm{SO}_{4}$. The solvent was evaporated and the residue was purified by silica gel chromatography using PE to afford $\mathbf{8 a}(64 \mathrm{mg}, 84 \%)$ as a green solid.<smiles>CC(=O)Oc1cn(C)c2ccccc12</smiles>

1-methyl-1H-indol-3-yl acetate (8a): The title compound was obtained as a green solid in $84 \%$ yield. $\mathbf{R}_{\mathbf{f}}=0.40$ (PE : EtOAc, $50: 1$ ). ${ }^{1}$ H NMR (400 MHz, CDCl $) \delta 7.53(\mathrm{~d}, J=8.0 \mathrm{~Hz}, 1 \mathrm{H}), 7.29-7.19$ (m, 3H), 7.11 (ddd, $J=7.9,6.7,1.3 \mathrm{~Hz}, 1 \mathrm{H}), 3.70(\mathrm{~s}, 3 \mathrm{H}), 2.33$ (s, 3H). ${ }^{13}$ C NMR (101 MHz, $\left.\mathbf{C D C l}_{3}\right) \delta 168.79,133.75,129.17,122.36$, $120.16,119.35,117.97,117.56,109.32,32.82,21.02$.

\section{Synthesis of 9a}

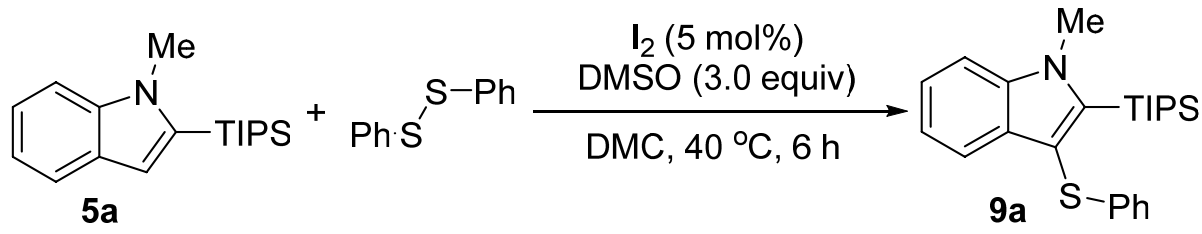

To a $13 \times 150 \mathrm{~mm}$ test tube equipped with magnetic stir bar were added 1-methyl-2-(triisopropylsilyl)-1H-indole (5a, $0.8 \mathrm{mmol}, 230 \mathrm{mg}$ ), diphenyl disulfide (1.5 equiv), $\mathrm{I}_{2}$ (5 mol\%), DMSO (3.0 equiv) and DMC (Dimethyl carbonate, $4.0 \mathrm{~mL}$ ) as solvent. The reaction mixture was stirred at $40{ }^{\circ} \mathrm{C}$ for $6 \mathrm{~h}$. The solvent was evaporated and the residue was purified by silica gel chromatography using PE to afford 9a (177 mg, 56\%).<smiles>Cn1c([I-]C(F)(F)F)c(-c2ccccc2)c2ccccc21</smiles>

1-methyl-3-(phenylthio)-2-(triisopropylsilyl)-1H-indole(9a): The title compound was obtained as an oil in $56 \%$ yield. $\mathbf{R}_{\mathbf{f}}=0.40$ (PE : EtOAc, $80: 1)$. ${ }^{\mathbf{1}} \mathbf{H}$ NMR (400 $\left.\mathbf{~ M H z , ~} \mathbf{C D C l}_{3}\right) \delta 7.52-7.46$ $(\mathrm{m}, 1 \mathrm{H}), 7.38(\mathrm{~d}, J=8.3 \mathrm{~Hz}, 1 \mathrm{H}), 7.30-7.24(\mathrm{~m}, 1 \mathrm{H}), 7.12-7.05$ $(\mathrm{m}, 3 \mathrm{H}), 6.98(\mathrm{td}, J=8.3,1.3 \mathrm{~Hz}, 3 \mathrm{H}), 3.94(\mathrm{~d}, J=2.8 \mathrm{~Hz}, 3 \mathrm{H})$, $1.97-1.84(\mathrm{~m}, 3 \mathrm{H}), 1.11(\mathrm{dd}, J=7.5,4.0 \mathrm{~Hz}, 18 \mathrm{H}) .{ }^{13} \mathbf{C}$ NMR (101 MHz, $\left.\mathbf{C D C l}_{3}\right) \delta$ $142.43,140.88,140.17,131.00,128.47,125.36,124.06,122.92,120.24,120.12$, 112.38, 109.58, 34.27, 19.18, 13.31. HRMS (EI) Calcd. for $\mathrm{C}_{24} \mathrm{H}_{34} \mathrm{SNSi}:[\mathrm{M}]^{+}$, 


\section{Synthesis of 10a}

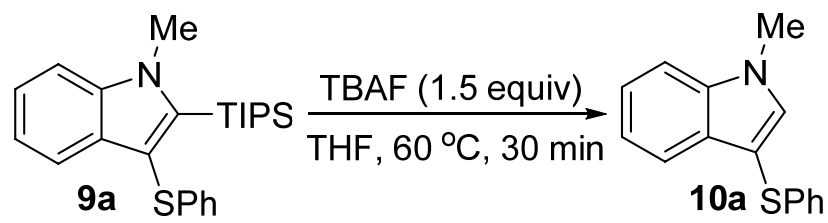

To a $13 \times 150 \mathrm{~mm}$ test tube equipped with magnetic stir bar were added 1-methyl-3-(phenylthio)-2-(triisopropylsilyl)-1H-indole (9a, $0.4 \mathrm{mmol}, 158 \mathrm{mg}$ ) in dry THF (4 mL) and tertabutylammonium fluoride hydrate (TBAF, $1 \mathrm{~mol} / \mathrm{L}$ in THF, $0.5 \mathrm{~mL})$. The reaction mixture was stirred at $60{ }^{\circ} \mathrm{C}$ for $30 \mathrm{~min}$. Water $(6 \mathrm{~mL})$ was added and the mixture was extracted with EtOAc $(5 \mathrm{~mL} \times 3)$. The organic layer was combined, washed with brine and dried over anhydrous $\mathrm{Na}_{2} \mathrm{SO}_{4}$. The solvent was evaporated and the residue was purified by silica gel chromatography using PE to afford 10a (78 $\mathrm{mg}, 81 \%)$ as a white solid.<smiles>Cn1cc(S)c2ccccc21</smiles>

1-methyl-3-(phenylthio)-1H-indole (10a): The title compound was obtained as a white solid $81 \%$ yield. $\mathbf{R}_{\mathbf{f}}=0.40$ (PE : EtOAc, $\left.20: 1\right) .{ }^{1} \mathbf{H}$ NMR (400 MHz, CDCl $) \delta 7.63-7.56(\mathrm{~m}, 1 \mathrm{H}), 7.31(\mathrm{~d}, J=8.2 \mathrm{~Hz}$, $1 \mathrm{H}), 7.28-7.20(\mathrm{~m}, 2 \mathrm{H}), 7.15-7.06(\mathrm{~m}, 5 \mathrm{H}), 7.02-6.96(\mathrm{~m}, 1 \mathrm{H})$, 3.69 (s, 3H). ${ }^{13} \mathbf{C}$ NMR (101 MHz, $\left.\mathbf{C D C l}_{3}\right) \delta 139.85,137.68,135.25$, $129.96,128.82,125.85,124.83,122.71,120.65,119.82,109.93,100.50,33.19$. HRMS (EI) Calcd. for $\mathrm{C}_{15} \mathrm{H}_{14} \mathrm{SN}$ : [M] $]^{+}, 240.0841$. Found: $m / z .240 .0841$

\section{Synthesis of 11a}

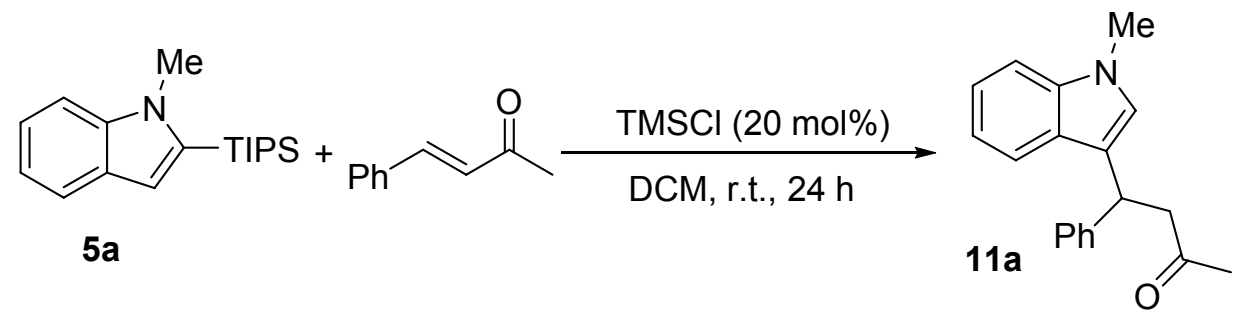

To a $13 \times 150 \mathrm{~mm}$ test tube equipped with magnetic stir bar were added 1-methyl-2-(triisopropylsilyl)-1H-indole (5a, $0.8 \mathrm{mmol}, 230 \mathrm{mg}$ ), (E)-4-phenyl-3buten-2-one (1.2 equiv), TMSCl (trimethyl chlorosilane, $20 \mathrm{~mol} \%$ ) and DCM (4 mL). The reaction mixture was stirred at room temperture for $24 \mathrm{~h}$. The solvent was evaporated and the residue was purified by silica gel chromatography using PE/EA (3:1) to afford 11a (169 mg, 76\%) as an oil liquid.

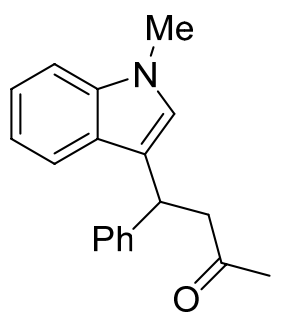

4-(1-methyl-1H-indol-3-yl)-4-phenylbutan-2-one (11a): The title compound was obtained as an oil liquid in $76 \%$ yield. $\mathbf{R}_{\mathbf{f}}=0.40$ (PE : EtOAc, $3:$ 1). ${ }^{1} \mathbf{H}$ NMR (400 MHz, $\left.\mathbf{C D C l}_{3}\right) \delta 7.42(\mathrm{~d}, J=$ $8.0 \mathrm{~Hz}, 1 \mathrm{H}), 7.32-7.28(\mathrm{~m}, 2 \mathrm{H}), 7.27-7.22(\mathrm{~m}, 3 \mathrm{H}), 7.19-7.13$ $(\mathrm{m}, 2 \mathrm{H}), 7.03-6.98(\mathrm{~m}, 1 \mathrm{H}), 6.81(\mathrm{~s}, 1 \mathrm{H}), 4.82(\mathrm{t}, J=7.6 \mathrm{~Hz}, 1 \mathrm{H})$, 
$3.70(\mathrm{~s}, 3 \mathrm{H}), 3.18(\mathrm{ddd}, J=36.0,16.1,7.6 \mathrm{~Hz}, 2 \mathrm{H}), 2.06$ (s, 3H). ${ }^{13} \mathrm{C}$ NMR (101 $\left.\mathbf{M H z}, \mathbf{C D C l}_{3}\right) \delta 207.66,144.18,137.34,128.53,127.73,126.96,126.38,126.21$, $121.78,119.53,118.94,117.36,109.28,50.51,38.41,32.74,30.39$. HRMS (EI) Calcd. for $\mathrm{C}_{19} \mathrm{H}_{20} \mathrm{ON}$ : [M] $]^{+}, 278.1539$. Found: $m / z .278 .1539$

\section{Synthesis of $N$-methylphenylhydrazines}

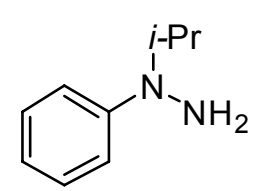

1-isopropyl-1-phenylhydrazine (1c): The title compound was obtained as a brown liquid in $73 \%$ yield $(5.48 \mathrm{~g}) . \quad \mathbf{R}_{\mathbf{f}}=0.43$ (PE:EtOAc, 6:1). ${ }^{1} \mathbf{H}$ NMR (400 MHz, $\left.\mathbf{C D C l}_{3}\right) \delta 7.31-7.23(\mathrm{~m}, 2 \mathrm{H})$, $7.04(\mathrm{dd}, \mathrm{J}=7.9,0.9 \mathrm{~Hz}, 2 \mathrm{H}), 6.79(\mathrm{td}, \mathrm{J}=7.2,1.0 \mathrm{~Hz}, 1 \mathrm{H}), 4.09(\mathrm{dt}$, $\mathrm{J}=13.0,6.5 \mathrm{~Hz}, 1 \mathrm{H}), 3.26(\mathrm{~s}, 2 \mathrm{H}), 1.18(\mathrm{~d}, \mathrm{~J}=1.2 \mathrm{~Hz}, 3 \mathrm{H}), 1.16(\mathrm{~d}, \mathrm{~J}=1.2 \mathrm{~Hz}, 3 \mathrm{H})$. ${ }^{13}$ C NMR (101 MHz, $\left.\mathbf{C D C l}_{3}\right) \delta 151.69,129.17,118.18,113.91,50.69,17.73$. HRMS (EI) Calcd. for $\mathrm{C}_{9} \mathrm{H}_{14} \mathrm{~N}_{2}:[\mathrm{M}]^{+}, 150.1157$. Found: $m / z$ 150.1154.<smiles>NN(c1ccccc1)c1ccccc1</smiles>

1,1-diphenylhydrazine (1d): The title compound was obtained as a brown liquid in $76 \%$ yield $(7.0 \mathrm{~g}) . \mathrm{Rf}=0.46$ (PE:EtOAc, $6: 1) .{ }^{1} \mathbf{H}$ NMR (400 MHz, CDCl $\left.{ }_{3}\right) \delta 7.31-7.25(\mathrm{~m}, 4 \mathrm{H}), 7.21$ (dd, J = 8.6, 1.0 $\mathrm{Hz}, 4 \mathrm{H}), 7.02-6.95(\mathrm{~m}, 2 \mathrm{H}), 4.27$ (s, 2H). ${ }^{13} \mathbf{C}$ NMR (101 MHz, $\left.\mathbf{C D C l}_{3}\right) \delta 149.24,129.14,122.01,119.54,77.47,77.14,76.82$. HRMS (EI) Calcd. for $\mathrm{C}_{12} \mathrm{H}_{12} \mathrm{~N}_{2}:[\mathrm{M}]^{+}, 184.1000$. Found: $\mathrm{m} / \mathrm{z} 184.0994$.

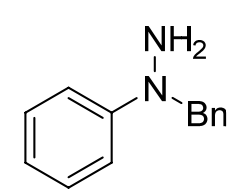

1-benzyl-1-phenylhydrazine (1e): The title compound was obtained as a brown liquid in 67\% yield (6.64 g). $\mathrm{Rf}=0.46\left(\mathrm{PE}\right.$ :EtOAc, 6:1). ${ }^{1} \mathbf{H}$ NMR (400 MHz, $\left.\mathbf{C D C l}_{3}\right) \delta 7.36-7.23(\mathrm{~m}, 7 \mathrm{H}), 7.12-7.05(\mathrm{~m}, 2 \mathrm{H})$, $6.81(\mathrm{t}, \mathrm{J}=7.3 \mathrm{~Hz}, 1 \mathrm{H}), 4.58(\mathrm{~s}, 2 \mathrm{H}), 3.47(\mathrm{~s}, 2 \mathrm{H}) .{ }^{13} \mathrm{C}$ NMR (101 MHz, $\left.\mathbf{C D C l}_{3}\right) \delta \delta 151.83,137.69,129.21,129.17,128.81,128.77,128.00,127.49$, 118.71, 113.77, 77.48, 77.17, 76.85, 60.42. HRMS (EI) Calcd. for Calcd. for $\mathrm{C}_{13} \mathrm{H}_{14} \mathrm{~N}_{2}:[\mathrm{M}]^{+}$, 198.1157. Found: $\mathrm{m} / \mathrm{z} 198.1156$.

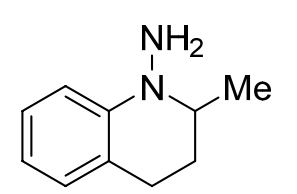

2-methyl-3,4-dihydroquinolin-1(2H)-amine (1i): The title compound was obtained as a oil liquid in $68 \%$ yield $(5.51 \mathrm{~g}) . \mathbf{R}_{\mathbf{f}}=$ 0.45 (PE:EtOAc, 5:1). ${ }^{\mathbf{1}} \mathbf{H}$ NMR (400 $\left.\mathbf{~ M H z , ~} \mathbf{C D C l}_{\mathbf{3}}\right) \delta 7.14-7.05$ $(\mathrm{m}, 2 \mathrm{H}), 6.99-6.91(\mathrm{~m}, 1 \mathrm{H}), 6.68(\mathrm{tdd}, J=5.5,2.7,1.3 \mathrm{~Hz}, 1 \mathrm{H})$, $3.61-3.41(\mathrm{~m}, 2 \mathrm{H}), 3.40-3.29(\mathrm{~m}, 1 \mathrm{H}), 2.79-2.68(\mathrm{~m}, 2 \mathrm{H}), 2.07-1.96(\mathrm{~m}, 1 \mathrm{H})$, $1.82(\mathrm{qd}, J=6.8,0.9 \mathrm{~Hz}, 1 \mathrm{H}), 1.26-1.18(\mathrm{~m}, 3 \mathrm{H}) .{ }^{\mathbf{1 3}} \mathbf{C}$ NMR (101 MHz, $\left.\mathbf{C D C l}_{3}\right) \delta$ $148.51,128.71,127.13,123.17,117.89,112.80,56.93,29.72,25.13,18.18$. HRMS (EI) Calcd. for $\mathrm{C}_{10} \mathrm{H}_{14} \mathrm{~N}_{2}$ : [M] $]^{+}, 162.1157$. Found: $m / z$ 162.1151.

\section{Synthesis and Characterization of Indole Derivatives}

\section{General procedure for the synthesis of indole derivatives:}




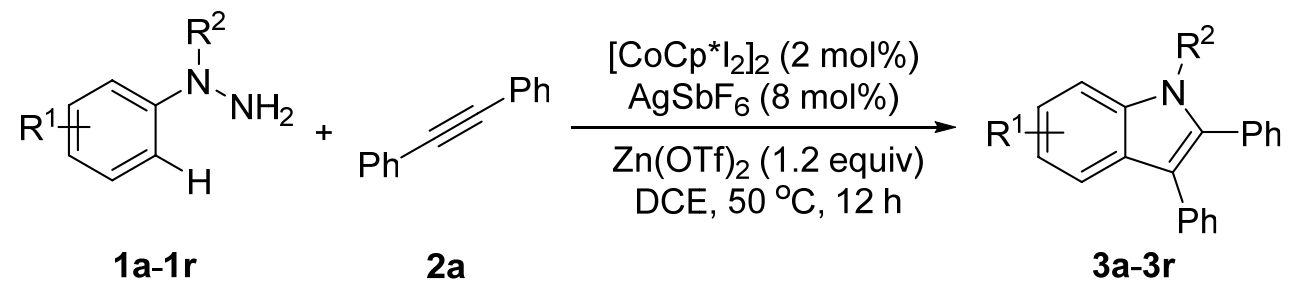<smiles>[R]C#C[PH3+]</smiles>

To a $13 \times 150 \mathrm{~mm}$ test tube equipped with magnetic stir bar was added 1-methyl-1-phenylhydrazine substrate (If the 1-methyl-1-phenylhydrazine substrate is a solid, it was added at this point). The test tube was transferred to a glovebox, and then $\left[\mathrm{Cp}^{*} \mathrm{CoI}_{2}\right]_{2}(7.16 \mathrm{mg}, 0.008 \mathrm{mmol}, 2 \mathrm{~mol} \%)$ and $\mathrm{AgSbF}_{6}(11 \mathrm{mg}, 0.032 \mathrm{mmol}, 8$ $\mathrm{mol} \%$ ) were further added. The test tube was sealed with a rubber septum and removed from the glovebox. The solution of 1-methyl-1-phenylhydrazine substrate (for liquid such as 1a, $48.8 \mathrm{mg}, 50 \mu \mathrm{L}, 0.4 \mathrm{mmol}, 1.0$ equiv) and alkyne (for example, $2 \mathrm{~s}, 76 \mu \mathrm{L}, 0.6 \mathrm{mmol}, 1.5$ equiv) in $2.0 \mathrm{~mL}$ of DCE was injected into the test tube via syringe. The reaction mixture was allowed to stir at $50{ }^{\circ} \mathrm{C}$ for $8-12 \mathrm{~h}$, during which time a constant checking by TLC was performed. Once the reaction proceeded to a desired degree, the reaction mixture was cooled to room temperature and filtered over celite. The solvent was then removed under reduced pressure and the residue was purified by flash column chromatography on silica gel with PE/EtOAc as the eluent. A white solid was obtained unless otherwise stated.<smiles>Cn1c(-c2ccccc2)c(-c2ccccc2)c2ccccc21</smiles>

1-methyl-2,3-diphenyl-1H-indole (3a): The title compound was obtained as a white solid in $88 \%$ yield $(99.7 \mathrm{mg}) . \mathbf{R}_{\mathbf{f}}=0.45$ (PE:EtOAc, 50:1). ${ }^{1} \mathbf{H}$ NMR (400 MHz, $\left.\mathbf{C D C l}_{3}\right) \delta 7.82(\mathrm{~d}, J=8.0$ $\mathrm{Hz}, 1 \mathrm{H}), 7.47-7.37(\mathrm{~m}, 4 \mathrm{H}), 7.36-7.26(\mathrm{~m}, 7 \mathrm{H}), 7.24-7.14(\mathrm{~m}$, 2H), 3.70 (s, 3H). ${ }^{13} \mathbf{C}$ NMR (101 MHz, $\left.\mathbf{C D C l}_{3}\right) \delta$ 137.92, 137.51, $135.41,132.09,131.35,130.07,128.58,128.37,128.22,127.15,125.69,122.37$, 120.39, 119.81, 115.28, 109.78, 31.14. HRMS (EI) Calcd. for $\mathrm{C}_{21} \mathrm{H}_{17} \mathrm{~N}$ : $[\mathrm{M}]^{+}$, 283.1361. Found: $m / z 283.1358$.<smiles>CCn1c(-c2ccccc2)c(-c2ccccc2)c2ccccc21</smiles>

1-ethyl-2,3-diphenyl-1H-indole (3b): the title compound was obtained as a white solid in $83 \%$ yield $(98.6 \mathrm{mg}) . \mathbf{R}_{\mathbf{f}}=0.45$ (PE:EtOAc, 50:1). ${ }^{\mathbf{1}} \mathbf{H}$ NMR (400 $\left.\mathbf{M H z}, \mathbf{C D C l}_{3}\right) \delta 7.81(\mathrm{~d}, J=7.8$ $\mathrm{Hz}, 1 \mathrm{H}), 7.43(\mathrm{~d}, J=8.1 \mathrm{~Hz}, 1 \mathrm{H}), 7.40-7.22(\mathrm{~m}, 10 \mathrm{H}), 7.16(\mathrm{dt}, J=$ 12.6, $6.5 \mathrm{~Hz}, 2 \mathrm{H}), 4.12(\mathrm{q}, J=7.1 \mathrm{~Hz}, 2 \mathrm{H}), 1.27$ (dd, $J=9.3,4.9 \mathrm{~Hz}$, 3H). ${ }^{13} \mathbf{C}$ NMR (101 MHz, $\left.\mathbf{C D C l}_{3}\right) \delta 137.32,136.11,135.26,132.30,131.11,129.86$, 128.46, 128.14, 127.29, 125.44, 122.07, 120.13, 119.81, 115.36, 109.83, 38.67, 15.43. HRMS (EI) Calcd. for $\mathrm{C}_{22} \mathrm{H}_{19} \mathrm{~N}:[\mathrm{M}]^{+}, 297.1517$. Found: $m / z$ 297.1529. 


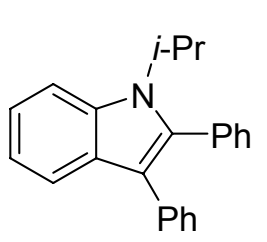

1-isopropyl-2,3-diphenyl-1H-indole (3c): the title compound was obtained as a white solid in $67 \%$ yield $(83.4 \mathrm{mg}) . \mathbf{R}_{\mathbf{f}}=0.45$ (PE:EtOAc, 50:1). ${ }^{1} \mathbf{H}$ NMR (400 MHz, $\left.\mathbf{C D C l}_{3}\right) \delta 7.79(\mathrm{~d}, J=7.9$ $\mathrm{Hz}, 1 \mathrm{H}), 7.65(\mathrm{~d}, J=8.3 \mathrm{~Hz}, 1 \mathrm{H}), 7.37(\mathrm{dd}, J=3.8,2.5 \mathrm{~Hz}, 3 \mathrm{H})$, $7.34-7.28(\mathrm{~m}, 2 \mathrm{H}), 7.23(\mathrm{dd}, J=7.8,3.6 \mathrm{~Hz}, 5 \mathrm{H}), 7.15(\mathrm{tt}, J=7.1$, $3.6 \mathrm{~Hz}, 2 \mathrm{H}), 4.71-4.32(\mathrm{~m}, 1 \mathrm{H}), 1.62(\mathrm{dd}, J=7.0,1.0 \mathrm{~Hz}, 6 \mathrm{H}) .{ }^{13} \mathbf{C}$ NMR (101 MHz, $\left.\mathbf{C D C l}_{3}\right) \delta 137.63,135.29,134.62,132.84,131.19,129.95,128.40,128.18,128.10$, 128.04, 125.39, 121.50, 119.94, 119.72, 115.16, 112.31, 47.92, 21.57. HRMS (EI) Calcd. for $\mathrm{C}_{23} \mathrm{H}_{21} \mathrm{~N}$ : [M] $]^{+}, 311.1674$. Found: $m / z 311.1681$.<smiles>c1ccc(-c2c(-c3ccccc3)n(-c3ccccc3)c3ccccc23)cc1</smiles>

1,2,3-triphenyl-1H-indole (3d): the title compound was obtained as a white solid in $51 \%$ yield $(70.4 \mathrm{mg}) . \mathbf{R}_{\mathbf{f}}=0.45$ (PE:EtOAc, 50:1). ${ }^{1} \mathbf{H}$ NMR (400 MHz, CDCl $) \quad \delta 7.83-7.76(\mathrm{~m}, 1 \mathrm{H}), 7.41-7.27$ $(\mathrm{m}, 8 \mathrm{H}), 7.25-7.20(\mathrm{~m}, 5 \mathrm{H}), 7.17-7.04(\mathrm{~m}, 5 \mathrm{H}) .{ }^{\mathbf{1 3}} \mathbf{C}$ NMR (101 $\left.\mathbf{M H z}, \mathbf{C D C l}_{3}\right) \delta 138.17,137.94,137.09,134.96,131.63,131.22$, $130.26,129.08,128.32,128.29,127.91,127.60,127.36,127.17,125.96,122.76$, 120.91, 119.62, 116.75, 110.68. HRMS (EI) Calcd. for $\mathrm{C}_{26} \mathrm{H}_{19} \mathrm{~N}:[\mathrm{M}]^{+}, 345.1517$. Found: $m / z 345.1508$.<smiles>c1ccc(Cn2c(-c3ccccc3)c(-c3ccccc3)c3ccccc32)cc1</smiles>

1-benzyl-2,3-diphenyl-1H-indole (3e): The title compound was obtained as a white solid in $73 \%$ yield $(104.9 \mathrm{mg}) . \mathbf{R}_{\mathbf{f}}=0.45$ (PE:EtOAc, 50:1). ${ }^{1} \mathbf{H}$ NMR (400 MHz, $\left.\mathbf{C D C l}_{3}\right) \quad \delta 7.82$ (dt, $J=$ 12.4, $5.5 \mathrm{~Hz}, 1 \mathrm{H}), 7.34(\mathrm{dd}, J=8.2,1.1 \mathrm{~Hz}, 2 \mathrm{H}), 7.31-7.12(\mathrm{~m}$, 14H), $7.01(\mathrm{~d}, J=7.1 \mathrm{~Hz}, 2 \mathrm{H}), 5.28(\mathrm{~s}, 2 \mathrm{H}) .{ }^{\mathbf{1 3}} \mathbf{C}$ NMR (101 MHz, $\left.\mathbf{C D C l}_{3}\right) \delta 138.16,137.94,137.03,135.17,131.83,131.13,129.97,128.73,128.45$, $128.24,128.22$, 127.43, 127.22, 126.17, 125.65, 122.43, 120.48, 119.78, 115.71, 110.58, 47.66. HRMS (EI) Calcd. for $\mathrm{C}_{27} \mathrm{H}_{21} \mathrm{~N}$ : $[\mathrm{M}]^{+}$, 359.1674. Found: $\mathrm{m} / z$ 359.1668 .<smiles>Cc1cccc2c(-c3ccccc3)c(-c3ccccc3)n(C)c12</smiles>

1,7-dimethyl-2,3-diphenyl-1H-indole (3f): The title compound was obtained as a white solid in $63 \%$ yield $(74.9 \mathrm{mg}) . \quad \mathbf{R}_{\mathbf{f}}=0.45$ (PE:EtOAc, 40:1). ${ }^{1} \mathbf{H}$ NMR (400 MHz, $\left.\mathbf{C D C l}_{3}\right) \delta 7.59(\mathrm{~d}, J=7.6$ $\mathrm{Hz}, 1 \mathrm{H}), 7.39-7.33(\mathrm{~m}, 3 \mathrm{H}), 7.32-7.28(\mathrm{~m}, 2 \mathrm{H}), 7.27-7.21(\mathrm{~m}$, $4 \mathrm{H}), 7.19-7.12(\mathrm{~m}, 1 \mathrm{H}), 7.08-6.96(\mathrm{~m}, 2 \mathrm{H}), 3.88(\mathrm{~s}, 3 \mathrm{H}), 2.84(\mathrm{~s}$, 3H). ${ }^{13} \mathbf{C}$ NMR (101 MHz, $\mathbf{C D C l}_{3}$ ) $\delta$ 138.92, 136.59, 135.32, 132.13, 131.39, 130.07, $128.33,128.10,128.06,127.97,125.53,125.26,121.46,120.33,117.73,115.69$, 34.33, 20.47. HRMS (EI) Calcd. for $\mathrm{C}_{22} \mathrm{H}_{19} \mathrm{~N}$ : [M] $]^{+}, 297.1517$. Found: $m / z$ 297.1513.

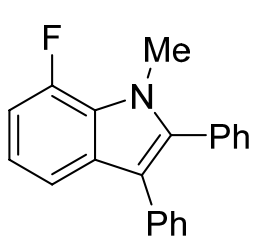

7-fluoro-1-methyl-2,3-diphenyl-1H-indole (3g): The title compound was obtained as a white solid in $71 \%$ yield $(85.5 \mathrm{mg}) . \mathbf{R}_{\mathbf{f}}$ $=0.40$ (PE:EtOAc, 40:1). ${ }^{1} \mathbf{H}$ NMR (400 MHz, $\left.\mathbf{C D C l}_{3}\right) \delta 7.51(\mathrm{~d}, J$ $=7.6 \mathrm{~Hz}, 1 \mathrm{H}), 7.41-7.34(\mathrm{~m}, 3 \mathrm{H}), 7.31(\mathrm{dt}, J=5.6,3.5 \mathrm{~Hz}, 2 \mathrm{H})$, $7.24(\mathrm{dd}, J=9.1,4.1 \mathrm{~Hz}, 4 \mathrm{H}), 7.17(\mathrm{dq}, J=8.8,4.2 \mathrm{~Hz}, 1 \mathrm{H}), 7.03$ (td, $J=7.9,4.6 \mathrm{~Hz}, 1 \mathrm{H}), 6.93(\mathrm{ddd}, J=12.7,7.8,0.8 \mathrm{~Hz}, 1 \mathrm{H}), 3.85(\mathrm{~d}, J=1.9 \mathrm{~Hz}, 3 \mathrm{H})$. 
${ }^{13}$ C NMR (101 MHz, $\left.\mathbf{C D C l}_{3}\right) \delta$ 151.63, 149.21, 139.21, 134.90, $131.32(\mathrm{~d}, J=3.9$ $\mathrm{Hz}), 130.99$ (d, $J=5.4 \mathrm{~Hz}), 129.96,128.55,128.38,128.33,125.90,125.43$ (d, $J=$ $9.0 \mathrm{~Hz}), 120.22$ (d, $J=6.7 \mathrm{~Hz}), 116.08,115.48(\mathrm{~d}, J=3.3 \mathrm{~Hz}), 107.88$ (d, $J=18.3$ $\mathrm{Hz}), 33.64(\mathrm{~d}, J=6.4 \mathrm{~Hz})$. HRMS (EI) Calcd. for $\mathrm{C}_{21} \mathrm{H}_{16} \mathrm{NF}$ : $[\mathrm{M}]^{+}, 301.1267$. Found: $\mathrm{m} / \mathrm{z} 301.1265$.

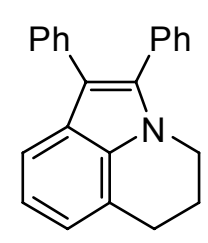

1,2-diphenyl-5,6-dihydro-4H-pyrrolo[3,2,1-ij]quinoline (3h): The title compound was obtained as a white solid in $69 \%$ yield $(85.3 \mathrm{mg}) . \mathbf{R}_{\mathbf{f}}=$ 0.45 (PE:EtOAc, 30:1). ${ }^{1} \mathbf{H}$ NMR (400 $\left.\mathbf{M H z}, \mathbf{C D C l}_{3}\right) \delta 7.62(\mathrm{~d}, J=7.9$ $\mathrm{Hz}, 1 \mathrm{H}), 7.38-7.29(\mathrm{~m}, 7 \mathrm{H}), 7.29-7.21(\mathrm{~m}, 2 \mathrm{H}), 7.18-7.12(\mathrm{~m}, 1 \mathrm{H})$, $7.08(\mathrm{dt}, J=7.8,5.7 \mathrm{~Hz}, 1 \mathrm{H}), 6.98(\mathrm{dd}, J=5.0,2.0 \mathrm{~Hz}, 1 \mathrm{H}), 4.04(\mathrm{dd}, J$ $=9.8,4.3 \mathrm{~Hz}, 2 \mathrm{H}), 3.02(\mathrm{t}, J=5.9 \mathrm{~Hz}, 2 \mathrm{H}), 2.28-2.13(\mathrm{~m}, 2 \mathrm{H}) .{ }^{13} \mathbf{C}$ NMR (101 MHz, $\left.\mathbf{C D C l}_{3}\right) \delta 136.10,135.73,134.44,131.89,130.81,129.79,128.50,128.30,127.92$, 125.43, 125.10, 122.13, 120.37, 119.26, 117.14, 114.55, 43.27, 25.19, 23.08. HRMS (EI) Calcd. for $\mathrm{C}_{23} \mathrm{H}_{19} \mathrm{~N}$ : [M] $]^{+}, 309.1517$. Found: $m / z$ 309.1512.

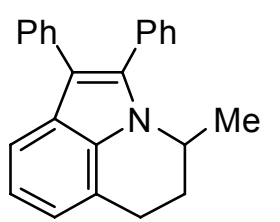

4-methyl-1,2-diphenyl-5,6-dihydro-4H-pyrrolo[3,2,1-ij]quinoline (3i): The title compound was obtained as a white solid in $63 \%$ yield (81.4 mg). $\mathbf{R}_{\mathbf{f}}=0.40$ (PE:EtOAc, 30:1). ${ }^{\mathbf{1}} \mathbf{H}$ NMR (400 $\mathbf{~ M H z ,}$ $\left.\mathbf{C D C l}_{3}\right){ }^{1} \mathrm{H}$ NMR $\left(400 \mathrm{MHz}, \mathrm{CDCl}_{3}\right) \delta 7.66(\mathrm{dd}, J=17.9,8.0 \mathrm{~Hz}$, $1 \mathrm{H}), 7.45-7.30(\mathrm{~m}, 7 \mathrm{H}), 7.30-7.23(\mathrm{~m}, 2 \mathrm{H}), 7.20-7.08(\mathrm{~m}, 2 \mathrm{H})$, $7.04(\mathrm{t}, J=10.8 \mathrm{~Hz}, 1 \mathrm{H}), 4.78-4.46(\mathrm{~m}, 1 \mathrm{H}), 3.27-3.07(\mathrm{~m}, 1 \mathrm{H}), 3.06-2.85(\mathrm{~m}$, $1 \mathrm{H}), 2.34(\mathrm{tt}, J=13.2,4.8 \mathrm{~Hz}, 1 \mathrm{H}), 2.18-2.00(\mathrm{~m}, 1 \mathrm{H}), 1.10(\mathrm{dd}, J=12.8,6.6 \mathrm{~Hz}$, 3H). ${ }^{13} \mathbf{C}$ NMR (101 MHz, $\left.\mathbf{C D C l}_{3}\right) \delta 135.96,135.70,133.60,132.31,131.03,129.65$, $128.59,128.23,128.12,125.35,125.32,121.47,120.36,119.37,117.04,115.22$, 46.93, 28.52, 20.85, 20.57. HRMS (EI) Calcd. for $\mathrm{C}_{24} \mathrm{H}_{21} \mathrm{~N}$ : $[\mathrm{M}]^{+}, 323.1674$. Found: $\mathrm{m} / \mathrm{z} 323.1680$.<smiles>Cc1ccc2c(-c3ccccc3)c(-c3ccccc3)n(C)c2c1</smiles>

1,6-dimethyl-2,3-diphenyl-1H-indole (3j): The title compound was obtained as a white solid in $65 \%$ yield $(77.3 \mathrm{mg}) . \mathbf{R}_{\mathbf{f}}=0.40$ (PE:EtOAc, 30:1). ${ }^{1} \mathbf{H}$ NMR (400 MHz, $\left.\mathbf{C D C l}_{3}\right) \delta 7.67$ (d, $J=$ $8.1 \mathrm{~Hz}, 1 \mathrm{H}), 7.37$ (q, $J=4.8 \mathrm{~Hz}, 3 \mathrm{H}), 7.34-7.26(\mathrm{~m}, 5 \mathrm{H}), 7.22$ $(\mathrm{d}, J=12.7 \mathrm{~Hz}, 2 \mathrm{H}), 7.18-7.12(\mathrm{~m}, 1 \mathrm{H}), 7.02(\mathrm{~d}, J=8.1 \mathrm{~Hz}$, 1H), 3.64 (s, 3H), 2.54 (s, 3H). ${ }^{\mathbf{1 3}} \mathbf{C}$ NMR (101 MHz, CDCl $) \delta 137.77,137.12$, $135.43,132.10,132.07,131.18,129.82,128.35,128.13,127.89,125.39,124.88$, 121.91, 119.31, 114.94, 109.57, 30.87, 21.93. HRMS (EI) Calcd. for $\mathrm{C}_{22} \mathrm{H}_{19} \mathrm{~N}$ : [M] 297.1517. Found: $m / z 297.1510$.<smiles>Cn1c(-c2ccccc2)c(-c2ccccc2)c2ccc(F)cc21</smiles>

6-fluoro-1-methyl-2,3-diphenyl-1H-indole (3k): The title compound was obtained as a white solid in $72 \%$ yield $(86.7 \mathrm{mg})$. $\mathbf{R}_{\mathbf{f}}=0.40$ (PE:EtOAc, 30:1). ${ }^{\mathbf{1}} \mathbf{H}$ NMR (400 $\left.\mathbf{M H z}, \mathbf{C D C l}_{\mathbf{3}}\right) \delta 7.35$ (ddd, $J=5.6,3.4,0.9 \mathrm{~Hz}, 3 \mathrm{H}), 7.27$ (td, $J=5.6,3.4 \mathrm{~Hz}, 4 \mathrm{H})$, $7.23-7.12(\mathrm{~m}, 5 \mathrm{H}), 6.83(\mathrm{ddd}, J=11.4,5.7,2.9 \mathrm{~Hz}, 1 \mathrm{H}), 3.66(\mathrm{~s}$,

3H). ${ }^{13}$ C NMR (101 MHz, $\left.\mathbf{C D C l}_{3}\right) \delta 158.23,155.76,139.90(\mathrm{~d}, J=11.0 \mathrm{~Hz}), 138.29$ 
(d, $J=1.3 \mathrm{~Hz}), 134.89$ (d, $J=1.0 \mathrm{~Hz}), 131.33(\mathrm{~d}, J=11.2 \mathrm{~Hz}), 130.94(\mathrm{~d}, J=2.6 \mathrm{~Hz})$, 128.43, 128.25, 127.56, 125.87, 122.34 (d, $J=8.2 \mathrm{~Hz}), 115.57$ (d, $J=18.1 \mathrm{~Hz})$, $113.61(\mathrm{~d}, J=3.0 \mathrm{~Hz}), 105.74,105.70,105.67,105.47,31.51$. HRMS (EI) Calcd. for $\mathrm{C}_{21} \mathrm{H}_{16} \mathrm{NF}:[\mathrm{M}]^{+}, 301.1267$. Found: $m / z 301.1258$.<smiles>Cn1c(-c2ccccc2)c(-c2ccccc2)c2ccc(Cl)cc21</smiles>

6-chloro-1-methyl-2,3-diphenyl-1H-indole (31): The title compound was obtained as a white solid in $76 \%$ yield $(96.4 \mathrm{mg})$. $\mathbf{R}_{\mathbf{f}}=0.45$ (PE:EtOAc, 30:1). ${ }^{1} \mathbf{H}$ NMR (400 $\left.\mathbf{M H z}, \mathbf{C D C l}_{3}\right) \delta$ $7.67(\mathrm{~d}, J=8.5 \mathrm{~Hz}, 1 \mathrm{H}), 7.42-7.35(\mathrm{~m}, 4 \mathrm{H}), 7.34-7.27(\mathrm{~m}$, $2 \mathrm{H}), 7.28-7.23(\mathrm{~m}, 4 \mathrm{H}), 7.18(\mathrm{ddd}, J=6.7,5.3,3.7 \mathrm{~Hz}, 1 \mathrm{H})$, $7.13(\mathrm{dd}, J=8.5,1.8 \mathrm{~Hz}, 1 \mathrm{H}), 3.63(\mathrm{~s}, 3 \mathrm{H}) .{ }^{13} \mathbf{C} \mathbf{N M R}\left(\mathbf{1 0 1} \mathbf{~ M H z}, \mathbf{C D C l}_{3}\right) \delta 138.30$, $137.80,134.68,131.45,131.09,129.79,128.49,128.30,128.28,128.01,125.82$, 125.62, 120.78, 120.57, 115.26, 109.63, 31.07. HRMS (EI) Calcd. for $\mathrm{C}_{21} \mathrm{H}_{16} \mathrm{NCl}$ : $[\mathrm{M}]^{+}, 317.0971$. Found: $m / z 317.0968$.<smiles>Cc1ccc2c(c1)c(-c1ccccc1)c(-c1ccccc1)n2C</smiles>

1,5-dimethyl-2,3-diphenyl-1H-indole (3m): The title compound was obtained as a white solid in $82 \%$ yield $(97.5 \mathrm{mg})$. $\mathbf{R}_{\mathbf{f}}=0.45$ (PE:EtOAc, 30:1). ${ }^{\mathbf{1}} \mathbf{H}$ NMR (400 $\left.\mathbf{~ M H z , ~} \mathbf{C D C l}_{3}\right) \delta$ 7.57 (s, 1H), $7.39-7.33(\mathrm{~m}, 3 \mathrm{H}), 7.29$ (ddd, $J=22.6,10.3,5.3$ $\mathrm{Hz}, 7 \mathrm{H}), 7.15$ (ddd, $J=14.0,7.9,5.1 \mathrm{~Hz}, 2 \mathrm{H}), 3.64$ (s, 3H), 2.47 (s, 3H). ${ }^{13} \mathbf{C}$ NMR (101 MHz, $\left.\mathbf{C D C l}_{3}\right) \delta$ 137.84, 135.84, 135.44, 132.06, 131.17, 129.94, 129.53, 128.36, 128.17, 127.94, 127.21, 125.43, 123.77, 119.19, 114.68, 109.30, 31.00, 21.58. HRMS (EI) Calcd. for $\mathrm{C}_{22} \mathrm{H}_{19} \mathrm{~N}$ : [M] $]^{+}$, 297.1517. Found: $\mathrm{m} / z$ 297.1514 .<smiles>COc1ccc2c(c1)c(-c1ccccc1)c(-c1ccccc1)n2C</smiles>

5-methoxy-1-methyl-2,3-diphenyl-1H-indole (3n): The title compound was obtained as a white solid in $76 \%$ yield $(95.2$ $\mathrm{mg}$ ). $\mathbf{R}_{\mathbf{f}}=0.45$ (PE:EtOAc, 10:1). ${ }^{\mathbf{1}} \mathbf{H}$ NMR (400 MHz, $\left.\mathbf{C D C l}_{3}\right) \delta 7.57(\mathrm{~s}, 1 \mathrm{H}), 7.37(\mathrm{dt}, J=10.0,3.4 \mathrm{~Hz}, 3 \mathrm{H}), 7.29$ (ddd, $J=16.7,10.8,5.4 \mathrm{~Hz}, 7 \mathrm{H}), 7.20-7.10(\mathrm{~m}, 2 \mathrm{H}), 3.65(\mathrm{~s}$,

3H), 2.47 (s, 3H). ${ }^{13} \mathbf{C}$ NMR (101 MHz, $\left.\mathbf{C D C l}_{3}\right) \delta 137.92,135.97,135.56,132.16$, $131.26,130.05,129.61,128.46,128.29,128.04,127.33,125.55,123.88,119.30$, 114.79, 109.43, 31.06, 21.70. HRMS (EI) Calcd. for $\mathrm{C}_{22} \mathrm{H}_{19} \mathrm{NO}$ : [M] $]^{+}, 313.1467$. Found: $m / z 313.1465$.<smiles>Cn1c(-c2ccccc2)c(-c2ccccc2)c2cc(F)ccc21</smiles>

5-fluoro-1-methyl-2,3-diphenyl-1H-indole (3o): The title compound was obtained as a white solid in $87 \%$ yield $(104.8 \mathrm{mg})$. $\mathbf{R}_{\mathbf{f}}=0.45$ (PE:EtOAc, 30:1). ${ }^{\mathbf{1}} \mathbf{H}$ NMR (400 MHz, $\left.\mathbf{C D C l}_{\mathbf{3}}\right) \delta 7.44$ $(\mathrm{dd}, J=9.9,2.5 \mathrm{~Hz}, 1 \mathrm{H}), 7.41-7.36(\mathrm{~m}, 3 \mathrm{H}), 7.34-7.29(\mathrm{~m}$, $3 \mathrm{H}), 7.28-7.23(\mathrm{~m}, 4 \mathrm{H}), 7.17(\mathrm{ddd}, J=7.1,5.6,2.4 \mathrm{~Hz}, 1 \mathrm{H})$, $7.04(\mathrm{td}, J=9.0,2.5 \mathrm{~Hz}, 1 \mathrm{H}), 3.67(\mathrm{~s}, 3 \mathrm{H}) .{ }^{\mathbf{1 3}} \mathbf{C} \mathbf{N M R}\left(\mathbf{1 0 1} \mathbf{M H z}, \mathbf{C D C l}_{\mathbf{3}}\right) \delta 159.69$, $157.36,139.30,134.80,133.98,131.61,131.06,129.65,128.48,128.32,128.26$, $127.25(\mathrm{~d}, J=9.8 \mathrm{~Hz}), 125.71,115.15(\mathrm{~d}, J=4.8 \mathrm{~Hz}), 110.57,110.25(\mathrm{~d}, J=10.8 \mathrm{~Hz})$, 104.61, 104.37, 31.19. HRMS (EI) Calcd. for $\mathrm{C}_{21} \mathrm{H}_{16} \mathrm{NF}$ : [M] $]^{+}, 301.1267$. Found: $\mathrm{m} / z$ 
<smiles>Cn1c(-c2ccccc2)c(-c2ccccc2)c2cc(Cl)ccc21</smiles>

5-chloro-1-methyl-2,3-diphenyl-1H-indole (3p): The title compound was obtained as a white solid in $81 \%$ yield $(102.7$ $\mathrm{mg}) . \mathbf{R}_{\mathbf{f}}=0.50$ (PE:EtOAc, 30:1). ${ }^{\mathbf{1}} \mathbf{H}$ NMR (400 $\left.\mathbf{M H z}, \mathbf{C D C l}_{\mathbf{3}}\right)$ $\delta 7.74(\mathrm{~d}, J=1.7 \mathrm{~Hz}, 1 \mathrm{H}), 7.40-7.35(\mathrm{~m}, 3 \mathrm{H}), 7.33-7.28(\mathrm{~m}$, $3 \mathrm{H}), 7.28-7.21(\mathrm{~m}, 5 \mathrm{H}), 7.18(\mathrm{ddd}, J=8.6,5.6,2.1 \mathrm{~Hz}, 1 \mathrm{H})$, 3.65 (s, 3H). ${ }^{13} \mathbf{C}$ NMR (101 MHz, $\left.\mathbf{C D C l}_{3}\right) \delta$ 139.01, 135.81, 134.62, 131.46, 131.11, $129.82,128.55,128.41,128.38,128.08,126.02,125.91,122.42,119.05,114.89$, 110.72, 31.17. HRMS (EI) Calcd. for $\mathrm{C}_{21} \mathrm{H}_{16} \mathrm{NCl}$ : [M] $]^{+}$, 317.0971. Found: $\mathrm{m} / \mathrm{z}$ 317.0965 .<smiles>Cn1c(-c2ccccc2)c(-c2ccccc2)c2cc(Br)ccc21</smiles>

5-bromo-1-methyl-2,3-diphenyl-1H-indole (3q): The title compound was obtained as a white solid in $73 \%$ yield $(105.4$ $\mathrm{mg}) . \mathbf{R}_{\mathbf{f}}=0.50$ (PE:EtOAc, 30:1). ${ }^{\mathbf{1}} \mathbf{H}$ NMR (400 MHz, $\left.\mathbf{C D C l}_{\mathbf{3}}\right)$ $\delta 7.88(\mathrm{~d}, J=1.7 \mathrm{~Hz}, 1 \mathrm{H}), 7.41-7.34(\mathrm{~m}, 4 \mathrm{H}), 7.34-7.28(\mathrm{~m}$, $2 \mathrm{H}), 7.25(\mathrm{dd}, J=10.2,6.0 \mathrm{~Hz}, 5 \mathrm{H}), 7.21-7.15(\mathrm{~m}, 1 \mathrm{H}), 3.65(\mathrm{~s}$, $3 \mathrm{H}) .{ }^{13} \mathbf{C}$ NMR (101 MHz, $\left.\mathbf{C D C l}_{3}\right) \delta 138.83,136.05,134.55,131.38,131.11,129.82$, $128.71,128.54,128.40,125.92,124.97,122.10,114.81,113.58,111.15,31.15$. HRMS (EI) Calcd. for $\mathrm{C}_{21} \mathrm{H}_{16} \mathrm{NBr}$ : [M] $]^{+}, 361.0466$. Found: $m / z$ 361.0460.<smiles>CC(=O)c1ccc2c(c1)c(-c1ccccc1)c(-c1ccccc1)n2C</smiles>

methyl 1-methyl-2,3-diphenyl-1H-indole-5-carboxylate (3r): The title compound was obtained as a yellow solid in $33 \%$ yield (45.0 mg). $\mathbf{R}_{\mathbf{f}}=0.45$ (PE:EtOAc, 10:1). ${ }^{1} \mathbf{H}$ NMR (400 MHz, $\left.\mathbf{C D C l}_{3}\right) \delta 8.55-8.49(\mathrm{~m}, 1 \mathrm{H}), 8.01(\mathrm{dd}$, $J=8.6,1.6 \mathrm{~Hz}, 1 \mathrm{H}), 7.42-7.36(\mathrm{~m}, 4 \mathrm{H}), 7.34-7.30(\mathrm{~m}$, 2H), $7.30-7.26(\mathrm{~m}, 4 \mathrm{H}), 7.23-7.17(\mathrm{~m}, 1 \mathrm{H}), 3.92(\mathrm{~s}, 3 \mathrm{H}), 3.69(\mathrm{~s}, 3 \mathrm{H}) .{ }^{13} \mathbf{C ~ N M R}$ (101 MHz, $\left.\mathbf{C D C l}_{3}\right) \delta 168.24,139.73,138.98,134.39,131.29,131.09,129.95,128.54$, $128.39,126.68,126.00,123.61,122.69,122.19,116.53,109.30,51.89,31.22$. HRMS (EI) Calcd. for $\mathrm{C}_{23} \mathrm{H}_{19} \mathrm{NO}_{2}$ : [M] $]^{+}, 341.1416$. Found: $m / z 341.1415$.<smiles>Cc1c(-c2ccccc2)n(C)c2ccccc12</smiles>

1,3-dimethyl-2-phenyl-1H-indole (3s): The title compound was obtained as a white solid in $90 \%$ yield $(80.0 \mathrm{mg}) . \mathbf{R}_{\mathbf{f}}=0.40$ (PE:EtOAc, 50:1). ${ }^{\mathbf{1}} \mathbf{H}$ NMR (400 MHz, $\left.\mathbf{C D C l}_{3}\right) \delta 7.66(\mathrm{~d}, J=7.8$ $\mathrm{Hz}, 1 \mathrm{H}), 7.57-7.51(\mathrm{~m}, 2 \mathrm{H}), 7.49-7.43(\mathrm{~m}, 3 \mathrm{H}), 7.39$ (d, $J=8.1$ $\mathrm{Hz}, 1 \mathrm{H}), 7.31$ (ddd, $J=8.2,7.0,1.2 \mathrm{~Hz}, 1 \mathrm{H}), 7.24-7.17(\mathrm{~m}, 1 \mathrm{H})$, 3.66 (s, 3H), 2.35 (s, 3H). ${ }^{13} \mathbf{C}$ NMR (101 MHz, $\left.\mathbf{C D C l}_{3}\right) \delta 137.77,137.39,132.31$, $130.78,128.62,128.49,127.88,121.91,119.29,118.98,31.04,9.56$. HRMS (ESI) Calcd. for $\mathrm{C}_{16} \mathrm{H}_{16} \mathrm{~N}$ : $[\mathrm{M}+\mathrm{H}]^{+}$, 222.1277. Found: $m / z 222.1277$.<smiles>CCc1c(-c2ccccc2)n(C)c2ccccc12</smiles>

3-ethyl-1-methyl-2-phenyl-1H-indole (3t): The title compound was obtained as a white solid in $87 \%$ yield $(81.8 \mathrm{mg}) . \quad \mathbf{R}_{\mathbf{f}}=0.45$ (PE:EtOAc, 50:1). ${ }^{\mathbf{1}} \mathbf{H}$ NMR (400 $\left.\mathbf{M H z}, \mathbf{C D C l}_{3}\right) \delta 7.72(\mathrm{~d}, J=7.8$ $\mathrm{Hz}, 1 \mathrm{H}), 7.57-7.50(\mathrm{~m}, 2 \mathrm{H}), 7.46$ (ddt, $J=7.9,5.7,1.4 \mathrm{~Hz}, 3 \mathrm{H})$, 
$7.39(\mathrm{~d}, J=8.2 \mathrm{~Hz}, 1 \mathrm{H}), 7.33-7.27(\mathrm{~m}, 1 \mathrm{H}), 7.23-7.17(\mathrm{~m}, 1 \mathrm{H}), 3.63(\mathrm{~s}, 3 \mathrm{H}), 2.78$ $(\mathrm{q}, J=7.5 \mathrm{~Hz}, 2 \mathrm{H}), 1.29$ (t, $J=7.5 \mathrm{~Hz}, 3 \mathrm{H}) .{ }^{13} \mathbf{C}$ NMR (101 MHz, CDCl $\left.\mathbf{3}\right) \delta 137.48$, $132.49,130.82,128.55,128.53,128.10,127.68,121.84,119.28,115.59,109.58$, 30.98, 18.15, 16.28. HRMS (EI) Calcd. for $\mathrm{C}_{17} \mathrm{H}_{17} \mathrm{~N}$ : $[\mathrm{M}]^{+}$, 235.1361. Found: $\mathrm{m} / \mathrm{z}$ 235.1365 .

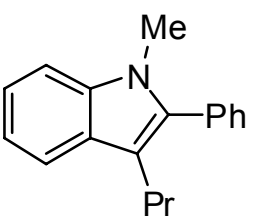

1-methyl-2-phenyl-3-propyl-1H-indole (3u): The title compound was obtained as a white solid in $89 \%$ yield $(88.7 \mathrm{mg}) . \mathbf{R}_{\mathbf{f}}=0.60$ (PE:EtOAc, 50:1). ${ }^{\mathbf{1}} \mathbf{H}$ NMR (400 MHz, $\left.\mathbf{C D C l}_{3}\right) \delta 7.62(\mathrm{~d}, J=7.8$ $\mathrm{Hz}, 1 \mathrm{H}), 7.44$ (ddd, $J=8.2,4.8,1.1 \mathrm{~Hz}, 2 \mathrm{H}), 7.41-7.32(\mathrm{~m}, 3 \mathrm{H})$, $7.30(\mathrm{~d}, J=8.1 \mathrm{~Hz}, 1 \mathrm{H}), 7.25-7.18(\mathrm{~m}, 1 \mathrm{H}), 7.15-7.07(\mathrm{~m}, 1 \mathrm{H}), 3.56-3.45(\mathrm{~m}$, $3 \mathrm{H}), 2.69-2.61(\mathrm{~m}, 2 \mathrm{H}), 1.66-1.55(\mathrm{~m}, 2 \mathrm{H}), 0.86(\mathrm{ddd}, J=10.4,6.0,3.1 \mathrm{~Hz}, 3 \mathrm{H})$. ${ }^{13} \mathbf{C}$ NMR (101 MHz, $\left.\mathbf{C D C l}_{3}\right) \delta 137.92,137.36,132.55,130.86,128.48,128.04$, $128.00,121.74,119.37,119.19,113.91,109.48,30.93,26.98,24.64,14.51$. HRMS (EI) Calcd. for $\mathrm{C}_{18} \mathrm{H}_{19} \mathrm{~N}$ : [M] $]^{+}, 249.1517$. Found: $m / z 249.1521$.

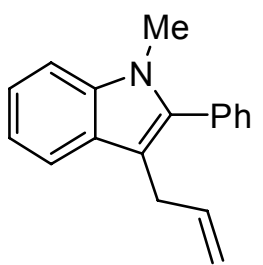

3-allyl-1-methyl-2-phenyl-1H-indole (3v): The title compound was obtained as a white solid in $65 \%$ yield $(64.3 \mathrm{mg}) . \mathbf{R}_{\mathbf{f}}=0.50$ (PE:EtOAc, 30:1). ${ }^{\mathbf{1}} \mathbf{H}$ NMR (400 $\left.\mathbf{~ M H z , ~} \mathbf{C D C l}_{3}\right) \delta 7.70$ (dd, $J=7.9$, $0.6 \mathrm{~Hz}, 1 \mathrm{H}), 7.58-7.51(\mathrm{~m}, 2 \mathrm{H}), 7.51-7.44(\mathrm{~m}, 3 \mathrm{H}), 7.44-7.39$ $(\mathrm{m}, 1 \mathrm{H}), 7.32(\mathrm{dd}, J=11.2,4.0 \mathrm{~Hz}, 1 \mathrm{H}), 7.22(\mathrm{dd}, J=7.8,7.0 \mathrm{~Hz}$, $1 \mathrm{H}), 6.21-5.86(\mathrm{~m}, 1 \mathrm{H}), 5.30-4.88(\mathrm{~m}, 2 \mathrm{H}), 3.68(\mathrm{~s}, 3 \mathrm{H}), 3.52(\mathrm{~d}, J=6.0 \mathrm{~Hz}, 2 \mathrm{H})$. ${ }^{13}$ C NMR (101 MHz, $\left.\mathbf{C D C l}_{3}\right) \delta 138.25,138.15,137.48,132.01,130.69,128.48$, 128.14, 127.96, 121.91, 119.45, 119.41, 114.76, 110.74, 109.52, 31.02, 29.42. HRMS (EI) Calcd. for $\mathrm{C}_{18} \mathrm{H}_{17} \mathrm{~N}$ : [M] $]^{+}, 247.1361$. Found: $m / z 247.1363$.

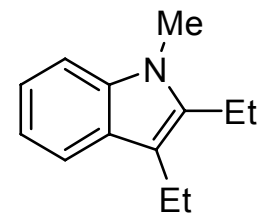

2,3-diethyl-1-methyl-1H-indole (3w): The title compound was obtained as a white solid in $59 \%$ yield $(44.2 \mathrm{mg}) . \quad \mathbf{R}_{\mathbf{f}}=0.55$ (PE:EtOAc, 70:1). ${ }^{1} \mathbf{H}$ NMR (400 $\left.\mathbf{~ M H z , ~} \mathbf{C D C l}_{3}\right) \delta 7.64(\mathrm{~d}, J=7.8$ $\mathrm{Hz}, 1 \mathrm{H}), 7.33$ (d, $J=8.0 \mathrm{~Hz}, 1 \mathrm{H}), 7.25-7.19$ (m, 1H), $7.19-7.10$ $(\mathrm{m}, 1 \mathrm{H}), 3.73(\mathrm{~s}, 3 \mathrm{H}), 2.91-2.74(\mathrm{~m}, 4 \mathrm{H}), 1.31(\mathrm{dtd}, J=10.1,7.5$, $2.9 \mathrm{~Hz}, 6 \mathrm{H}) .{ }^{13} \mathbf{C}$ NMR (101 MHz, $\left.\mathbf{C D C l}_{3}\right) \delta 138.07,136.85,127.65,120.67,118.74$, 118.34, 112.80, 108.80, 29.43, 17.81, 16.47, 15.09. HRMS (EI) Calcd. for $\mathrm{C}_{13} \mathrm{H}_{17} \mathrm{~N}$ : $[\mathrm{M}]^{+}$, 187.1361. Found: $m / z$ 187.1364.

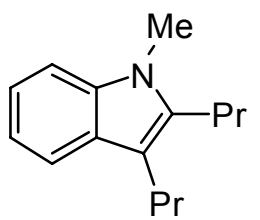

1-methyl-2,3-dipropyl-1H-indole (3x): The title compound was obtained as a white solid in $61 \%$ yield $(52.5 \mathrm{mg}) .{ }^{1} \mathbf{H}$ NMR (400 MHz, $\left.\mathbf{C D C l}_{3}\right) \delta 7.58(\mathrm{dd}, \mathrm{J}=7.8,0.7 \mathrm{~Hz}, 1 \mathrm{H}), 7.32-7.27(\mathrm{~m}, 1 \mathrm{H})$, $7.24-7.15(\mathrm{~m}, 1 \mathrm{H}), 7.15-7.06(\mathrm{~m}, 1 \mathrm{H}), 3.70(\mathrm{~s}, 3 \mathrm{H}), 2.80-2.71$ (m, 4H), 1.67 (ddt, J = 22.4, 14.8, 7.5 Hz, 4H), $1.09-1.00(\mathrm{~m}, 6 \mathrm{H})$.

${ }^{13}$ C NMR (101 MHz, CDCl $\mathbf{~}_{3} \delta$ 137.01, 136.86, 128.06, 120.55, 118.62, 118.49, 111.81, 108.68, 29.64, 26.87, 26.69, 24.59, 23.65, 14.48, 14.19. HRMS (EI) Calcd. for $\mathrm{C}_{15} \mathrm{H}_{21} \mathrm{~N}:[\mathrm{M}]^{+}, 215.1674$. Found: $m / z 215.1679$. 
<smiles>Cn1c(CC(C)(C)C)c(C(C)(C)C)c2ccccc21</smiles>

2,3-dibutyl-1-methyl-1H-indole (3y): The title compound was obtained as a white solid in $53 \%$ yield $(51.6 \mathrm{mg}) . \mathbf{R}_{\mathbf{f}}=0.60$ (PE:EtOAc, 70:1). ${ }^{\mathbf{1}} \mathbf{H}$ NMR (400 MHz, $\left.\mathbf{C D C l}_{3}\right) \delta 7.59(\mathrm{~d}, J=7.7$ $\mathrm{Hz}, 1 \mathrm{H}), 7.29(\mathrm{~d}, J=8.1 \mathrm{~Hz}, 1 \mathrm{H}), 7.24-7.17(\mathrm{~m}, 1 \mathrm{H}), 7.12(\mathrm{dd}, J=$ $10.8,4.0 \mathrm{~Hz}, 1 \mathrm{H}), 3.70(\mathrm{~d}, J=0.5 \mathrm{~Hz}, 3 \mathrm{H}), 2.77$ (dd, $J=16.9,8.8$ $\mathrm{Hz}, 4 \mathrm{H}), 1.68(\mathrm{dd}, J=15.1,7.7 \mathrm{~Hz}, 2 \mathrm{H}), 1.60(\mathrm{dd}, J=15.7,7.9 \mathrm{~Hz}, 2 \mathrm{H}), 1.55-1.39$ $(\mathrm{m}, 4 \mathrm{H}), 1.01(\mathrm{q}, J=7.1 \mathrm{~Hz}, 6 \mathrm{H}) .{ }^{\mathbf{1 3}} \mathbf{C}$ NMR (101 MHz, $\left.\mathbf{C D C l}_{3}\right) \delta 137.14,136.98$, $128.15,120.65,118.74,118.54,111.87,108.80,33.93,32.74,32.68,29.65,24.51$, 23.17, 22.93, 14.39, 14.21, 14.15. HRMS (EI) Calcd. for $\mathrm{C}_{17} \mathrm{H}_{25} \mathrm{~N}$ : [M] ${ }^{+}, 243.1987$. Found: $m / z 243.1991$.

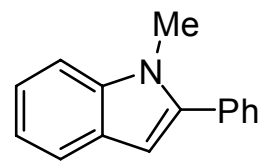

1-methyl-2-phenyl-1H-indole (3z): The title compound was obtained as a white solid in $43 \%$ yield $(35.6 \mathrm{mg}) . \mathbf{R}_{\mathbf{f}}=0.42$ (PE:EtOAc, 30:1). ${ }^{\mathbf{1}} \mathbf{H}$ NMR (400 MHz, $\left.\mathbf{C D C l}_{3}\right) \delta 7.69(\mathrm{~d}, J=7.8$ $\mathrm{Hz}, 1 \mathrm{H}), 7.56$ (dt, $J=7.9,1.7 \mathrm{~Hz}, 2 \mathrm{H}), 7.53-7.48(\mathrm{~m}, 2 \mathrm{H}), 7.47-$ 7.38 (m, 2H), 7.30 (ddd, $J=8.2,7.1,1.2 \mathrm{~Hz}, 1 \mathrm{H}), 7.22-7.17(\mathrm{~m}, 1 \mathrm{H}), 6.61(\mathrm{~s}, 1 \mathrm{H})$, 3.78 (s, 3H). ${ }^{13} \mathbf{C}$ NMR (101 MHz, $\left.\mathbf{C D C l}_{3}\right) \delta 141.75,138.54,133.03,129.56,128.68$, 128.15, 128.04, 121.86, 120.67, 120.05, 109.81, 101.84, 31.35. HRMS (EI) Calcd. for $\mathrm{C}_{15} \mathrm{H}_{13} \mathrm{~N}$ : [M] $]^{+}, 207.1048$. Found: $\mathrm{m} / \mathrm{z} 207.1049$.

\section{General Procedure for the Synthesis of Indole Derivatives}

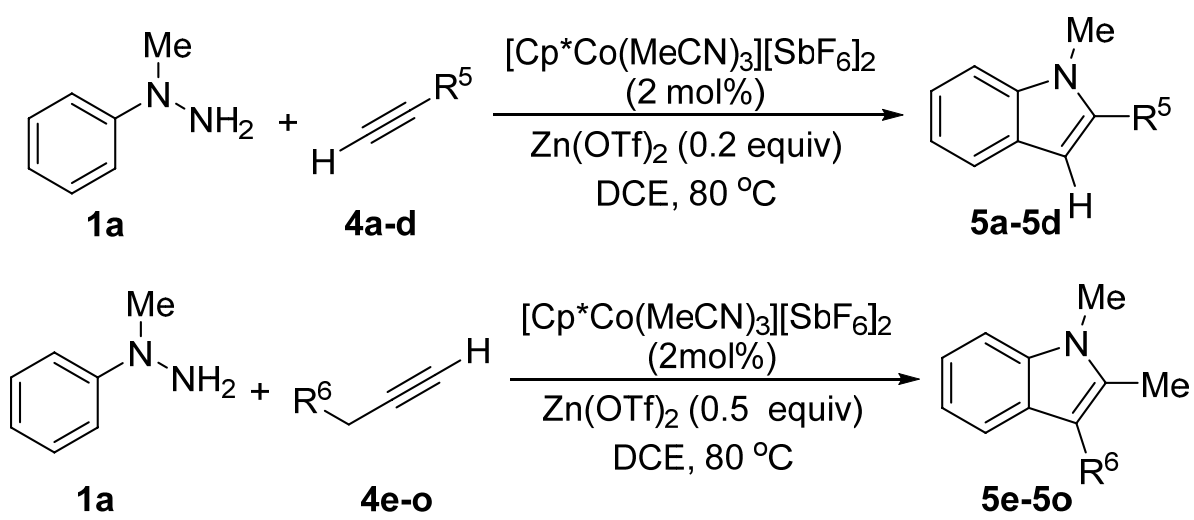

To a $13 \times 150 \mathrm{~mm}$ test tube equipped with magnetic stir bar was added $\mathrm{Zn}(\mathrm{OTf})_{2}$ (29 mg, $0.08 \mathrm{mmol}, 0.2$ equiv or $72 \mathrm{mg}, 0.20 \mathrm{mmol}, 0.5$ equiv). The test tube was transferred to a glovebox, and then $\left[\mathrm{Cp}^{*} \mathrm{Co}\left(\mathrm{CH}_{3} \mathrm{CN}\right)_{3}\right]\left[\mathrm{SbF}_{6}\right]_{2}(6.3 \mathrm{mg}, 0.008 \mathrm{mmol}, 2$ mol\%) was further added. The test tube was sealed with a rubber septum and removed from the glovebox. A solution of $\mathbf{1 a}(48.9 \mathrm{mg}, 0.40 \mathrm{mmol}, 1.0$ equiv) and $\mathbf{4 a}$ (109.2 $\mathrm{mg}, 0.60 \mathrm{mmol}, 1.5$ equiv) in $2.0 \mathrm{~mL}$ of DCE was injected into the test tube via syringe. The reaction mixture was stirred for $12 \mathrm{~h}$ at $80{ }^{\circ} \mathrm{C}$, during which time a constant checking by TLC was performed. The reaction mixture was cooled to room temperature and filtered over celite. The solvent was then removed under reduced pressure and the residue was purified by flash column chromatography on silica gel with 100:1 hexanes/EtOAc as the eluent. A white solid was obtained unless otherwise 
stated.

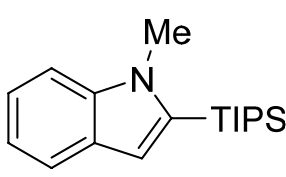

1-methyl-2-(triisopropylsilyl)-1H-indole (5a): The title compound was obtained as a white solid in $83 \%$ yield $(95.4 \mathrm{mg})$. $\mathbf{R}_{\mathbf{f}}=0.45$ (PE:EtOAc, 100:1). ${ }^{\mathbf{1}} \mathbf{H}$ NMR (400 $\left.\mathbf{M H z}, \mathbf{C D C l}_{\mathbf{3}}\right) \delta 7.62$ $(\mathrm{d}, J=7.9 \mathrm{~Hz}, 1 \mathrm{H}), 7.33(\mathrm{dd}, J=8.3,0.7 \mathrm{~Hz}, 1 \mathrm{H}), 7.22$ (ddd, $J=$ 8.2, 7.0, $1.2 \mathrm{~Hz}, 1 \mathrm{H}), 7.08$ (ddd, $J=7.8,7.0,0.9 \mathrm{~Hz}, 1 \mathrm{H}), 6.78$ (d, $J=0.7 \mathrm{~Hz}, 1 \mathrm{H})$, $3.84(\mathrm{~s}, 3 \mathrm{H}), 1.52-1.42(\mathrm{~m}, 3 \mathrm{H}), 1.14(\mathrm{~d}, J=7.5 \mathrm{~Hz}, 18 \mathrm{H}) .{ }^{13} \mathbf{C}$ NMR (101 MHz, $\left.\mathbf{C D C l}_{3}\right) \delta 140.27,136.90,128.59,121.72,120.48,118.98,114.07,109.11,33.62$, 18.96, 12.36. HRMS (EI) Calcd. for $\mathrm{C}_{18} \mathrm{H}_{29} \mathrm{NSi}$ : [M] ${ }^{+}$, 287.2069. Found: $\mathrm{m} / \mathrm{z}$ 287.2060 .

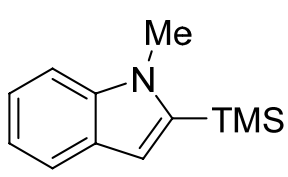

1-methyl-2-(trimethylsilyl)-1H-indole (5b) : The title compound was obtained as a oil liquid in $39 \%$ yield $(31.7 \mathrm{mg}) . \mathbf{R}_{\mathbf{f}}=0.40$ (PE:EtOAc, 100:1). ${ }^{\mathbf{1}} \mathbf{H}$ NMR (400 MHz, $\left.\mathbf{C D C l}_{3}\right) \delta 7.65(\mathrm{~d}, J=$ $7.9 \mathrm{~Hz}, 1 \mathrm{H}), 7.36(\mathrm{dd}, J=8.3,0.6 \mathrm{~Hz}, 1 \mathrm{H}), 7.29-7.23(\mathrm{~m}, 1 \mathrm{H})$, $7.14-7.09(\mathrm{~m}, 1 \mathrm{H}), 3.88(\mathrm{~s}, 3 \mathrm{H}), 0.46-0.41$ (m, 9H). ${ }^{13} \mathbf{C}$ NMR (101 MHz, $\left.\mathbf{C D C l}_{3}\right)$ $\delta 141.28,140.36,128.52,122.22,120.88,119.35,111.54,109.23,33.16,-0.27$. HRMS (EI) Calcd. for $\mathrm{C}_{12} \mathrm{H}_{17} \mathrm{NSi}$ : [M] $]^{+}$, 203.1130. Found: $m / z 203.1129$.<smiles>Cn1c([I-]#[SH])cc2ccccc21</smiles>

1-methyl-2-(triethylsilyl)-1H-indole (5c) : The title compound was obtained as a oil liquid in $51 \%$ yield $(50.0 \mathrm{mg}) . \mathbf{R}_{\mathbf{f}}=0.40$ (PE:EtOAc, 100:1). ${ }^{\mathbf{1}} \mathbf{H}$ NMR (400 MHz, $\left.\mathbf{C D C l}_{\mathbf{3}}\right) \delta 7.66(\mathrm{~d}, \mathrm{~J}=7.8$ $\mathrm{Hz}, 1 \mathrm{H}), 7.37(\mathrm{~d}, \mathrm{~J}=8.2 \mathrm{~Hz}, 1 \mathrm{H}), 7.26(\mathrm{~d}, \mathrm{~J}=15.1 \mathrm{~Hz}, 1 \mathrm{H}), 7.12(\mathrm{t}$, $\mathrm{J}=7.1 \mathrm{~Hz}, 1 \mathrm{H}), 6.77(\mathrm{~s}, 1 \mathrm{H}), 3.87(\mathrm{~s}, 3 \mathrm{H}), 1.05(\mathrm{dd}, \mathrm{J}=8.0,6.9 \mathrm{~Hz}, 9 \mathrm{H}), 0.99-0.92$ $(\mathrm{m}, 6 \mathrm{H}) .{ }^{\mathbf{1 3}} \mathbf{C}$ NMR (101 MHz, $\left.\mathbf{C D C l}_{3}\right) \delta 140.07,138.12,128.42,121.72,120.43$, 118.89, 112.82, 108.91, 32.86, 7.43, 3.88. HRMS (ESI) Calcd. for $\mathrm{C}_{15} \mathrm{H}_{24} \mathrm{NSi}$ : $[\mathrm{M}+\mathrm{H}]^{+}, 246.1673$. Found: $m / z 246.1673$.<smiles>Cn1c(Br)cc2ccccc21</smiles>

2-(tert-butyl)-1-methyl-1H-indole (5d) : The title compound was obtained as a oil liquid in $43 \%$ yield $(32.2 \mathrm{mg}) . \mathbf{R}_{\mathbf{f}}=0.40$ (PE:EtOAc, 100:1). ${ }^{\mathbf{1}} \mathbf{H}$ NMR (400 MHz, $\left.\mathbf{C D C l}_{\mathbf{3}}\right) \delta 7.57$ (d, $J=$ $7.7 \mathrm{~Hz}, 1 \mathrm{H}), 7.30(\mathrm{~d}, J=8.2 \mathrm{~Hz}, 1 \mathrm{H}), 7.23-7.16(\mathrm{~m}, 1 \mathrm{H}), 7.10(\mathrm{t}$, $J=7.4 \mathrm{~Hz}, 1 \mathrm{H}), 6.34(\mathrm{~s}, 1 \mathrm{H}), 3.90(\mathrm{~s}, 3 \mathrm{H}), 1.51(\mathrm{~s}, 9 \mathrm{H}) .{ }^{13} \mathbf{C}$ NMR (101 MHz, $\left.\mathbf{C D C l}_{3}\right) \delta 149.37,138.86,127.43,121.06,120.19,119.52,108.83$, 98.24, 32.54, 30.45. HRMS (EI) Calcd. for $\mathrm{C}_{13} \mathrm{H}_{17} \mathrm{~N}$ : [M] $]^{+}$, 187.1361. Found: $\mathrm{m} / \mathrm{z}$ 187.1362 .<smiles>CCc1c(C)n(C)c2ccccc12</smiles>

3-ethyl-1,2-dimethyl-1H-indole (5e): The title compound was obtained as a oil liquid in $29 \%$ yield $(20.1 \mathrm{mg}) . \mathbf{R}_{\mathbf{f}}=0.40$ (PE:EtOAc, 100:1). ${ }^{1} \mathbf{H}$ NMR (400 MHz, $\left.\mathbf{C D C l}_{3}\right) \delta 7.55(\mathrm{~d}, J=7.7$ $\mathrm{Hz}, 1 \mathrm{H}), 7.26(\mathrm{~d}, J=8.1 \mathrm{~Hz}, 1 \mathrm{H}), 7.19-7.14(\mathrm{~m}, 1 \mathrm{H}), 7.09(\mathrm{td}, J=$ $7.5,1.0 \mathrm{~Hz}, 1 \mathrm{H}), 3.66(\mathrm{~s}, 3 \mathrm{H}), 2.76(\mathrm{q}, J=7.5 \mathrm{~Hz}, 2 \mathrm{H}), 2.37(\mathrm{~s}, 3 \mathrm{H})$, $1.24(\mathrm{t}, J=7.6 \mathrm{~Hz}, 3 \mathrm{H}) .{ }^{13} \mathbf{C}$ NMR (101 MHz, $\left.\mathbf{C D C l}_{3}\right) \delta 136.54,132.09,127.41$, 
120.39, 118.52, 118.01, 113.23, 108.52, 29.45, 17.69, 15.82, 10.08. HRMS (ESI) Calcd. for $\mathrm{C}_{12} \mathrm{H}_{15} \mathrm{~N}$ : [M] $]^{+}, 173.1204$. Found: $m / z$ 173.1200.

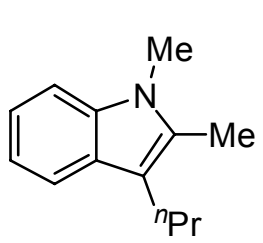

1,2-dimethyl-3-propyl-1H-indole (5f): The title compound was obtained as a oil liquid in $32 \%$ yield $(24.0 \mathrm{mg}) . \mathbf{R}_{\mathbf{f}}=0.40$ (PE:EtOAc, 100:1). ${ }^{\mathbf{1}} \mathbf{H}$ NMR (400 MHz, $\left.\mathbf{C D C l}_{3}\right) \delta 7.61-7.54(\mathrm{~m}$, $1 \mathrm{H}), 7.27(\mathrm{~d}, \mathrm{~J}=8.0 \mathrm{~Hz}, 1 \mathrm{H}), 7.19(\mathrm{dt}, \mathrm{J}=8.0,2.8 \mathrm{~Hz}, 1 \mathrm{H}), 7.12(\mathrm{dd}$, $\mathrm{J}=3.9,2.9 \mathrm{~Hz}, 1 \mathrm{H}), 3.65(\mathrm{~s}, 3 \mathrm{H}), 2.78-2.69(\mathrm{~m}, 2 \mathrm{H}), 2.38(\mathrm{~s}, 3 \mathrm{H})$, $1.75-1.64(\mathrm{~m}, 2 \mathrm{H}), 1.00(\mathrm{dt}, \mathrm{J}=4.2,3.5 \mathrm{~Hz}, 3 \mathrm{H}) .{ }^{13} \mathbf{C}$ NMR (101 MHz, $\left.\mathbf{C D C l}_{3}\right) \delta$ 136.72, 132.88, 128.07, 120.52, 118.68, 118.31, 111.66, 108.64, 29.61, 26.70, 24.46, 14.34, 10.43. HRMS (ESI) Calcd. for $\mathrm{C}_{13} \mathrm{H}_{17} \mathrm{~N}$ : $[\mathrm{M}]^{+}$, 187.1361. Found: $\mathrm{m} / \mathrm{z}$ 187.1358<smiles>CCCCc1c(C)n(C)c2ccccc12</smiles>

3-butyl-1,2-dimethyl-1H-indole (5g): The title compound was obtained as a oil liquid in $35 \%$ yield $(28.2 \mathrm{mg}) . \quad \mathbf{R}_{\mathbf{f}}=0.40$ (PE:EtOAc, 100:1). ${ }^{\mathbf{1}} \mathbf{H}$ NMR (400 MHz, $\left.\mathbf{C D C l}_{3}\right) \delta 7.60(\mathrm{~d}, \mathrm{~J}=7.7$ $\mathrm{Hz}, 1 \mathrm{H}), 7.32-7.28(\mathrm{~m}, 1 \mathrm{H}), 7.24-7.18(\mathrm{~m}, 1 \mathrm{H}), 7.14$ (ddd, $\mathrm{J}=$ 8.2, 2.2, $1.1 \mathrm{~Hz}, 1 \mathrm{H}), 3.70(\mathrm{t}, \mathrm{J}=3.7 \mathrm{~Hz}, 3 \mathrm{H}), 2.79(\mathrm{t}, \mathrm{J}=7.5 \mathrm{~Hz}$, 2H), $2.41(\mathrm{~s}, 3 \mathrm{H}), 1.72-1.61(\mathrm{~m}, 2 \mathrm{H}), 1.51-1.39(\mathrm{~m}, 2 \mathrm{H}), 1.01(\mathrm{td}, \mathrm{J}=7.3,1.3 \mathrm{~Hz}$, 3H). ${ }^{13} \mathbf{C}$ NMR (101 MHz, $\left.\mathbf{C D C l}_{3}\right) \delta 136.72,132.73,128.04,120.53,118.67,118.30$, 111.90, 108.66, 33.63, 29.64, 24.39, 22.91, 14.32, 10.43. HRMS (EI) Calcd. for $\mathrm{C}_{14} \mathrm{H}_{19} \mathrm{~N}:[\mathrm{M}]^{+}, 201.1517$. Found: $\mathrm{m} / \mathrm{z} 201.1521$.

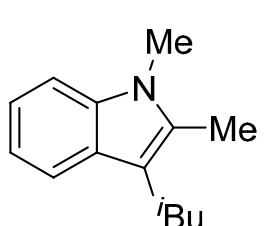

3-isobutyl-1,2-dimethyl-1H-indole (5h) : The title compound was obtained as a oil liquid in $41 \%$ yield $(33.0 \mathrm{mg}) . \quad \mathbf{R}_{\mathbf{f}}=0.40$ (PE:EtOAc, 100:1). ${ }^{\mathbf{1}} \mathbf{H}$ NMR (400 MHz, $\left.\mathbf{C D C l}_{3}\right) \delta 7.57(\mathrm{~d}, J=7.7$ $\mathrm{Hz}, 1 \mathrm{H}), 7.30(\mathrm{~d}, J=8.1 \mathrm{~Hz}, 1 \mathrm{H}), 7.21(\mathrm{dd}, J=8.0,7.1 \mathrm{~Hz}, 1 \mathrm{H})$, $7.13(\mathrm{ddd}, J=8.3,2.4,1.2 \mathrm{~Hz}, 1 \mathrm{H}), 3.70(\mathrm{~d}, J=0.8 \mathrm{~Hz}, 3 \mathrm{H}), 2.65$ $(\mathrm{dd}, J=7.1,1.8 \mathrm{~Hz}, 2 \mathrm{H}), 2.40(\mathrm{~d}, J=1.2 \mathrm{~Hz}, 3 \mathrm{H}), 2.07-1.93(\mathrm{~m}, 1 \mathrm{H}), 1.01(\mathrm{dd}, J=$ 6.6, $1.8 \mathrm{~Hz}, 6 \mathrm{H}) .{ }^{13} \mathbf{C}$ NMR (101 $\left.\mathbf{~ M H z}, \mathbf{C D C l}_{\mathbf{3}}\right) \delta 136.57,133.21,128.32,120.34$, $118.51,118.39,110.87,108.45,33.92,30.24,29.54,22.85,10.54$. HRMS (ESI) Calcd. for $\mathrm{C}_{14} \mathrm{H}_{19} \mathrm{~N}$ : $[\mathrm{M}+\mathrm{H}]^{+}, 201.1517$. Found: $m / z 201.1512$<smiles>Cn1c([18OH])c([18OH])c2ccccc21</smiles>

1,2-dimethyl-3-pentyl-1H-indole (5i): The title compound was obtained as a oil liquid in $43 \%$ yield $(37.0 \mathrm{mg}) . \mathbf{R}_{\mathbf{f}}=0.40$ (PE:EtOAc, 100:1). ${ }^{\mathbf{1}} \mathbf{H}$ NMR (400 MHz, $\left.\mathbf{C D C l}_{3}\right) \delta 7.61(\mathrm{~d}, \mathrm{~J}=7.8$ $\mathrm{Hz}, 1 \mathrm{H}), 7.31(\mathrm{~d}, \mathrm{~J}=8.1 \mathrm{~Hz}, 1 \mathrm{H}), 7.25-7.19(\mathrm{~m}, 1 \mathrm{H}), 7.18-7.12$ $(\mathrm{m}, 1 \mathrm{H}), 3.70(\mathrm{~s}, 3 \mathrm{H}), 2.84-2.74(\mathrm{~m}, 2 \mathrm{H}), 2.42(\mathrm{~s}, 3 \mathrm{H}), 1.70(\mathrm{dq}, \mathrm{J}$ $=9.8,7.4 \mathrm{~Hz}, 2 \mathrm{H}), 1.50-1.37(\mathrm{~m}, 4 \mathrm{H}), 1.02-0.93(\mathrm{~m}, 3 \mathrm{H}) .{ }^{13} \mathbf{C}$ NMR (101 MHz, $\left.\mathbf{C D C l}_{3}\right) \delta 136.72,132.71,128.02,120.53,118.68,118.30,111.95,108.65,32.07$, 31.10, 29.63, 24.64, 22.90, 14.37, 10.42. HRMS (EI) Calcd. for $\mathrm{C}_{15} \mathrm{H}_{21} \mathrm{~N}$ : $[\mathrm{M}]^{+}$, 215.1674. Found: m/z 215.1679. 


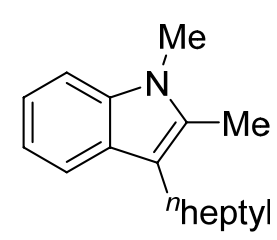

1,2-dimethyl-3-heptyl-1H-indole (5j) : The title compound was obtained as a oil liquid in $45 \%$ yield $(44.0 \mathrm{mg}) . \mathbf{R}_{\mathbf{f}}=0.40$ (PE:EtOAc, 100:1). ${ }^{\mathbf{1}} \mathbf{H}$ NMR (400 MHz, $\left.\mathbf{C D C l}_{3}\right) \delta 7.51(\mathrm{~d}, J=7.7$ $\mathrm{Hz}, 1 \mathrm{H}), 7.23(\mathrm{~d}, J=7.0 \mathrm{~Hz}, 1 \mathrm{H}), 7.16-7.10(\mathrm{~m}, 1 \mathrm{H}), 7.09-7.02$ $(\mathrm{m}, 1 \mathrm{H}), 3.64(\mathrm{~s}, 3 \mathrm{H}), 2.69(\mathrm{t}, J=7.6 \mathrm{~Hz}, 2 \mathrm{H}), 2.53-2.17(\mathrm{~m}, 3 \mathrm{H})$, $1.65-1.53(\mathrm{~m}, 2 \mathrm{H}), 1.35-1.22(\mathrm{~m}, 8 \mathrm{H}), 0.87(\mathrm{t}, J=6.9 \mathrm{~Hz}, 3 \mathrm{H}) .{ }^{13} \mathrm{C}$ NMR (101 $\left.\mathbf{M H z}, \mathbf{C D C l}_{3}\right) \delta 136.53,132.52,127.81,120.33,118.47,118.12,111.78,108.46$, 31.99, 31.24, 29.68, 29.48, 29.35, 24.49, 22.76, 14.18, 10.26. HRMS (ESI) Calcd. for $\mathrm{C}_{17} \mathrm{H}_{26} \mathrm{~N}:[\mathrm{M}+\mathrm{H}]^{+}, 244.2060$. Found: m/z 244.2060.

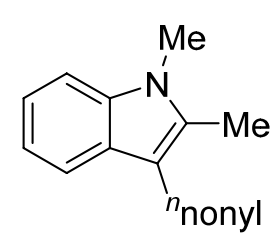

1,2-dimethyl-3-nonyl-1H-indole (5k) : The title compound was obtained as a oil liquid in $49 \%$ yield $(53.4 \mathrm{mg}) . \quad \mathbf{R}_{\mathbf{f}}=0.40$ (PE:EtOAc, 100:1). ${ }^{\mathbf{1}} \mathbf{H}$ NMR (400 MHz, $\left.\mathbf{C D C l}_{3}\right) \delta 7.59(\mathrm{~d}, J=7.6$ $\mathrm{Hz}, 1 \mathrm{H}), 7.30(\mathrm{~d}, J=8.1 \mathrm{~Hz}, 1 \mathrm{H}), 7.21(\mathrm{t}, J=7.5 \mathrm{~Hz}, 1 \mathrm{H}), 7.13(\mathrm{t}, J$ $=7.4 \mathrm{~Hz}, 1 \mathrm{H}), 3.71(\mathrm{~d}, J=7.2 \mathrm{~Hz}, 3 \mathrm{H}), 2.77(\mathrm{t}, J=7.5 \mathrm{~Hz}, 2 \mathrm{H})$, $2.41(\mathrm{~s}, 3 \mathrm{H}), 1.75-1.61(\mathrm{~m}, 2 \mathrm{H}), 1.37(\mathrm{~d}, J=23.1 \mathrm{~Hz}, 12 \mathrm{H}), 0.99-0.93(\mathrm{~m}, 3 \mathrm{H}) .{ }^{13} \mathrm{C}$ NMR (101 MHz, $\left.\mathbf{C D C l}_{3}\right) \delta 136.58,132.53,127.88,120.37,118.52,118.15,111.83$, $108.49,32.00,31.27,29.76,29.74,29.48,29.47,24.54,22.76,14.20,10.28$. HRMS (ESI) Calcd. for $\mathrm{C}_{19} \mathrm{H}_{30} \mathrm{~N}:[\mathrm{M}+\mathrm{H}]^{+}, 272.2373$. Found: m/z 272.2372.

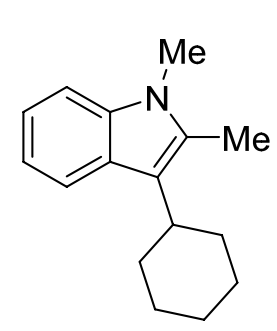

1,2-dimethyl-3-cyclohexyl-1H-indole (5l) : The title compound was obtained as oil liquid in $46 \%$ yield $(42.0 \mathrm{mg}) . \mathbf{R}_{\mathbf{f}}=0.40$ (PE:EtOAc, 100:1). ${ }^{\mathbf{1}} \mathbf{H}$ NMR (400 $\left.\mathbf{M H z}, \mathbf{C D C l}_{\mathbf{3}}\right) \delta 7.72(\mathrm{~d}, J=7.9$ $\mathrm{Hz}, 1 \mathrm{H}), 7.24(\mathrm{~s}, 1 \mathrm{H}), 7.12(\mathrm{dd}, J=11.1,4.0 \mathrm{~Hz}, 1 \mathrm{H}), 7.04(\mathrm{t}, J=$ $7.5 \mathrm{~Hz}, 1 \mathrm{H}), 3.64(\mathrm{~s}, 3 \mathrm{H}), 2.77(\mathrm{tt}, J=12.1,3.4 \mathrm{~Hz}, 1 \mathrm{H}), 2.41-2.34$ $(\mathrm{m}, 3 \mathrm{H}), 2.01-1.84(\mathrm{~m}, 4 \mathrm{H}), 1.79(\mathrm{~d}, J=11.8 \mathrm{~Hz}, 3 \mathrm{H}), 1.50-1.33$ $(\mathrm{m}, 3 \mathrm{H}) .{ }^{13} \mathbf{C}$ NMR (101 MHz, $\left.\mathbf{C D C l}_{3}\right) \delta$ 136.70, 131.46, 126.53, 120.07, 119.61, 118.19, 116.62, 108.66, 36.97, 33.32, 29.43, 27.48, 26.45, 10.59 . HRMS (ESI) Calcd. for $\mathrm{C}_{16} \mathrm{H}_{22} \mathrm{~N}$ : $[\mathrm{M}+\mathrm{H}]^{+}, 228.1747$. Found: $\mathrm{m} / \mathrm{z} 228.1747$.<smiles>Cc1c(Br)c2ccccc2n1C</smiles>

1,2-dimethyl-3-benzyl-1H-indole (5m): The title compound was obtained as a white solid in $51 \%$ yield $(47.8 \mathrm{mg}) . \mathbf{R}_{\mathbf{f}}=0.40$ (PE:EtOAc, 90:1). ${ }^{\mathbf{1}} \mathbf{H}$ NMR (400 $\left.\mathbf{M H z}, \mathbf{C D C l}_{3}\right) \delta 7.48(\mathrm{~d}, J=7.8$ $\mathrm{Hz}, 1 \mathrm{H}), 7.31-7.24(\mathrm{~m}, 5 \mathrm{H}), 7.23-7.16(\mathrm{~m}, 2 \mathrm{H}), 7.11-7.05(\mathrm{~m}$, 1H), 4.14 (s, 2H), 3.68 (s, 3H), 2.40 (d, $J=1.0 \mathrm{~Hz}, 3 \mathrm{H}) .{ }^{13} \mathbf{C}$ NMR (101 MHz, $\left.\mathbf{C D C l}_{\mathbf{3}}\right) \delta 142.15,136.82,133.73,128.52,128.46,128.41,128.14,125.80$, 120.75, 119.03, 118.48, 109.95, 108.71, 30.58, 29.71, 10.58. HRMS (ESI) Calcd. for $\mathrm{C}_{17} \mathrm{H}_{17} \mathrm{~N}:[\mathrm{M}+\mathrm{H}]^{+}, 235.1361$. Found: $\mathrm{m} / \mathrm{z} 235.1363$.

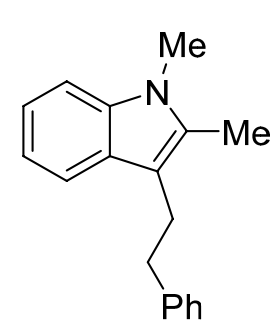

1,2-dimethyl-3-phenethyl-1H-indole (5n): The title compound was obtained as a white solid in $67 \%$ yield $(67.0 \mathrm{mg}) . \mathbf{R}_{\mathbf{f}}=0.40$ (PE:EtOAc, 90:1). ${ }^{\mathbf{1}} \mathbf{H}$ NMR (400 MHz, $\left.\mathbf{C D C l}_{3}\right) \delta 7.68-7.61(\mathrm{~m}$, $1 \mathrm{H}), 7.26(\mathrm{~d}, J=2.1 \mathrm{~Hz}, 7 \mathrm{H}), 7.20-7.13(\mathrm{~m}, 1 \mathrm{H}), 3.68(\mathrm{~d}, J=1.1$ $\mathrm{Hz}, 3 \mathrm{H}), 3.08(\mathrm{dd}, J=5.5,2.5 \mathrm{~Hz}, 2 \mathrm{H}), 2.98(\mathrm{dd}, J=5.3,3.0 \mathrm{~Hz}$, 
2H), $2.21(\mathrm{~d}, J=1.5 \mathrm{~Hz}, 3 \mathrm{H}) .{ }^{13} \mathbf{C}$ NMR (101 MHz, $\left.\mathbf{C D C l}_{3}\right) \delta 142.64,136.68,133.19$, $128.71,128.31,127.63,125.82,120.54,118.73,117.95,110.54,108.64,37.49,29.53$, 27.03, 9.98. HRMS (ESI) Calcd. for $\mathrm{C}_{18} \mathrm{H}_{20} \mathrm{~N}$ : [M] $]^{+}, 250.1590$. Found: m/z 250.1590.

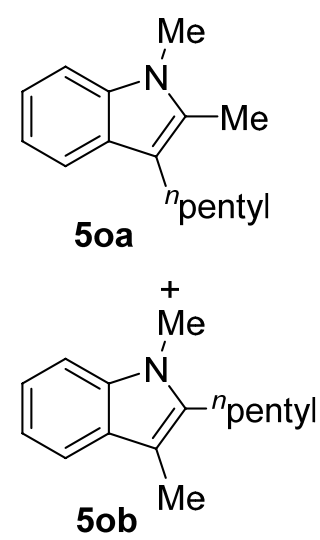

\section{1,2-dimethyl-3-pentyl-1H-indole(5oa), 1,3-dimethyl-2-pentyl}

-1H-indole(5ob): The title compound was obtained as a oil liquid unseparated in $42 \%$ yield $\left(36.0 \mathrm{mg}\right.$ ). $\mathbf{R}_{\mathbf{f}}=0.40$ (PE:EtOAc, 100:1). ${ }^{1} \mathbf{H}$ NMR (400 MHz, $\left.\mathbf{C D C l}_{3}\right) \delta 7.62(\mathrm{t}, J=7.9 \mathrm{~Hz}, 1 \mathrm{H}$ $\times 1+1 \mathrm{H} \times 0.72), 7.33(\mathrm{~d}, J=7.9 \mathrm{~Hz}, 1 \mathrm{H} \times 1+1 \mathrm{H} \times$ $0.72), 7.25(\mathrm{t}, J=10.6 \mathrm{~Hz}, 1 \mathrm{H} \times 1+1 \mathrm{H} \times 0.72), 7.18(\mathrm{dd}, J$ $=14.6,7.2 \mathrm{~Hz}, 1 \mathrm{H} \times 1+1 \mathrm{H} \times 0.72), 3.72(\mathrm{dt}, J=8.5,2.5 \mathrm{~Hz}$, $3 \mathrm{H} \times 1+3 \mathrm{H} \times 0.72), 2.82(\mathrm{dd}, J=16.2,8.3 \mathrm{~Hz}, 2 \mathrm{H} \times 1+$ $2 \mathrm{H} \times 0.72), 2.44(\mathrm{~m}, J=16.2,8.3 \mathrm{~Hz}, 3 \mathrm{H} \times 1), 2.37(\mathrm{~m}, J=$ $16.2,8.3 \mathrm{~Hz}, 3 \mathrm{H} \times 0.72), 1.69(\mathrm{dd}, J=16.2,8.3 \mathrm{~Hz}, 2 \mathrm{H} \times 1$ $+2 \mathrm{H} \times 0.72), 1.46(\mathrm{~d}, J=7.9 \mathrm{~Hz}, 4 \mathrm{H} \times 1+4 \mathrm{H} \times 0.72)$, $1.073(\mathrm{~m}, J=16.2,8.3 \mathrm{~Hz}, 3 \mathrm{H} \times 0.72) .{ }^{13} \mathbf{C}$ NMR (101 MHz, $\left.\mathbf{C D C l}_{3}\right) \delta 137.35$, $136.78,136.73,132.70,128.61,128.03,120.70,120.53,118.76,118.68,118.30$, $118.18,111.95,108.69,108.65,106.44,32.07,31.75,31.10,29.83,29.71,29.62$, 24.63, 22.90, 22.78, 14.37, 14.27, 10.42, 9.06. HRMS (ESI) Calcd. for $\mathrm{C}_{15} \mathrm{H}_{21} \mathrm{~N}$ : $[\mathrm{M}+\mathrm{H}]^{+}, 215.1674$. Found: $\mathrm{m} / \mathrm{z} 215.1668$.

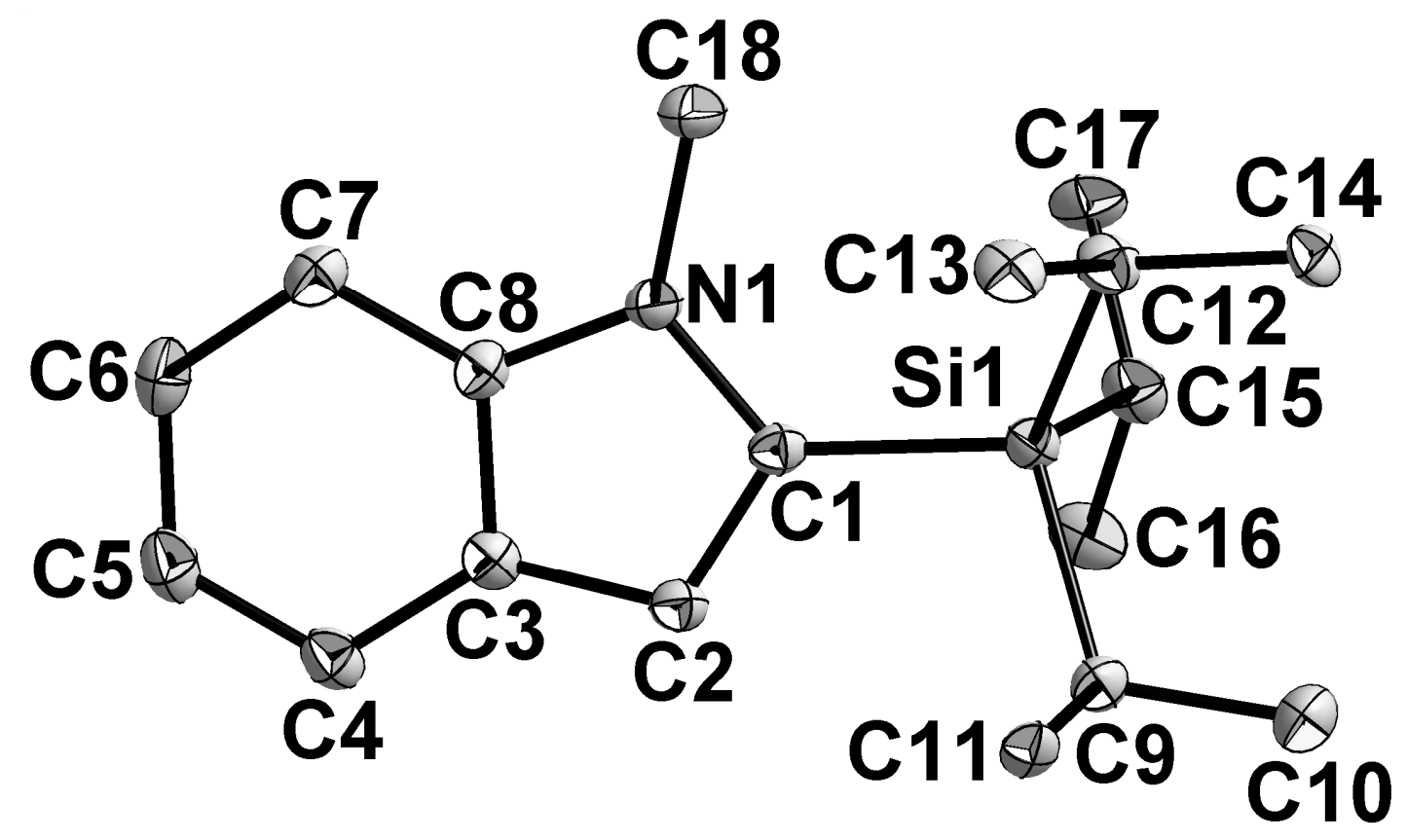

Figure S7. ORTEP drawing of 5a showing 30\% probability thermal ellipsoids, Hydrogen atoms have been omitted for clarity. 


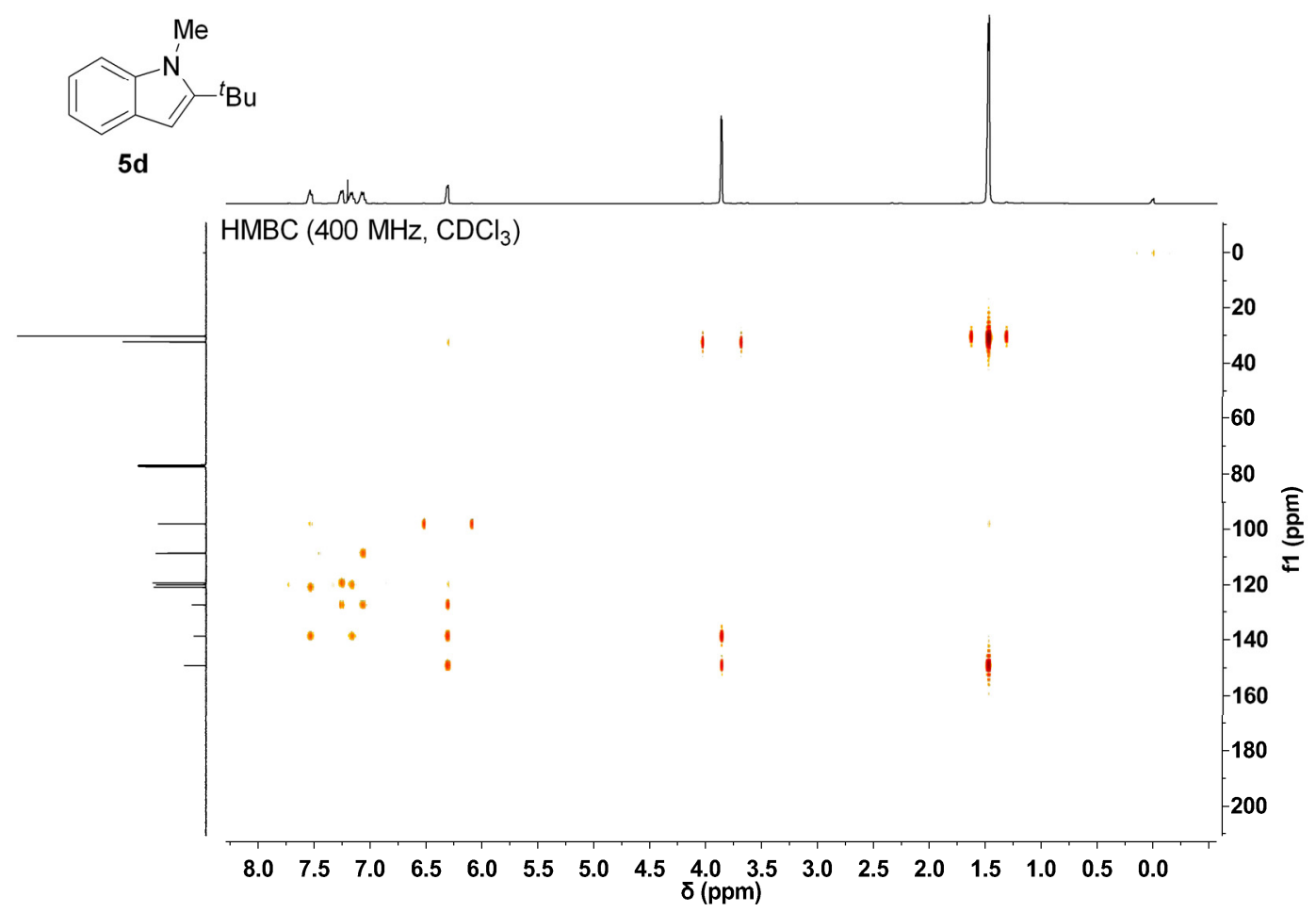

Figure S8. The $\mathrm{HMBC}\left(400 \mathrm{MHz}, \mathrm{CDCl}_{3}\right)$ of $\mathbf{5 d}$

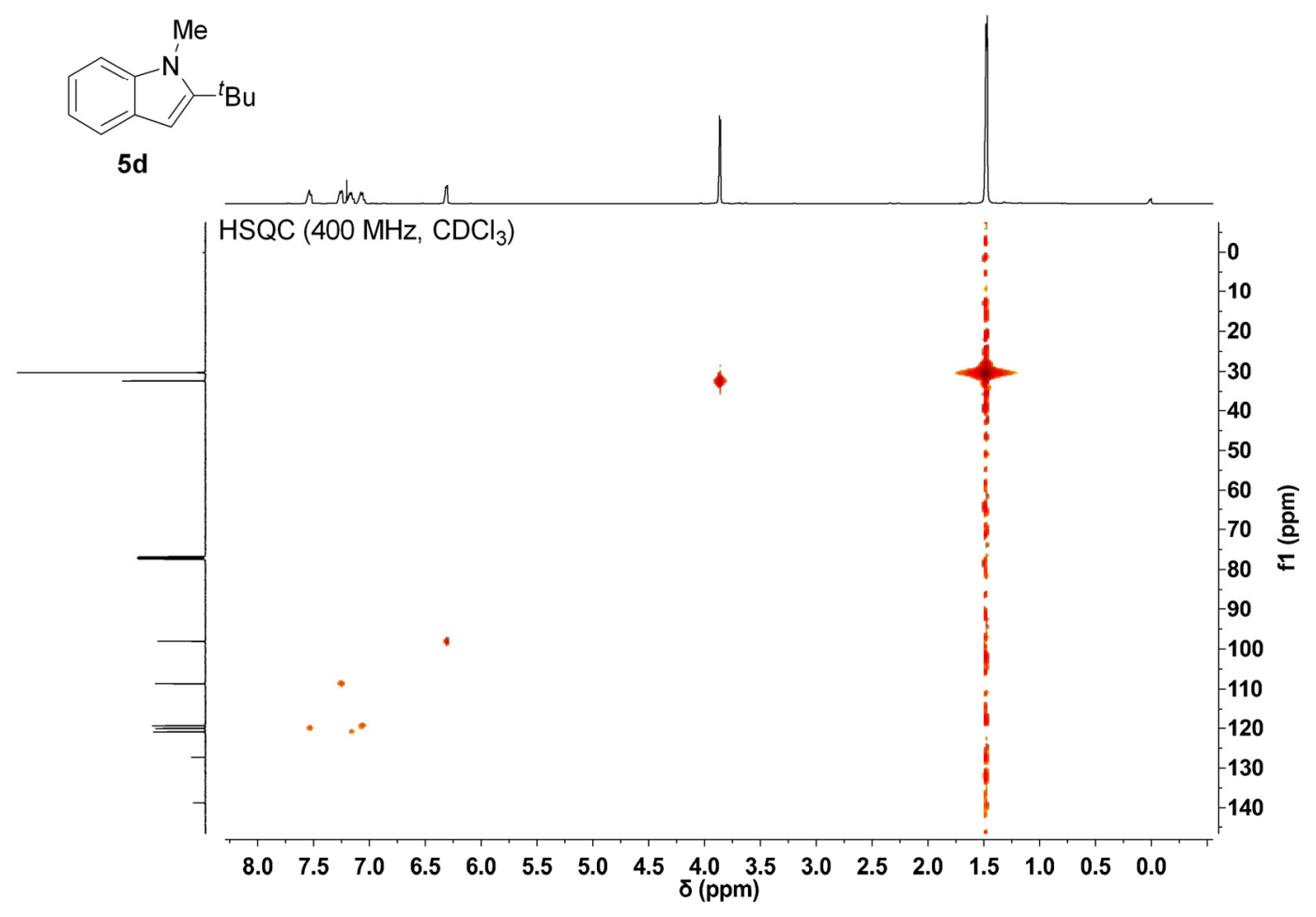

Figure S9. The HSQC (400 MHz, $\left.\mathrm{CDCl}_{3}\right)$ of $\mathbf{5 d}$ 


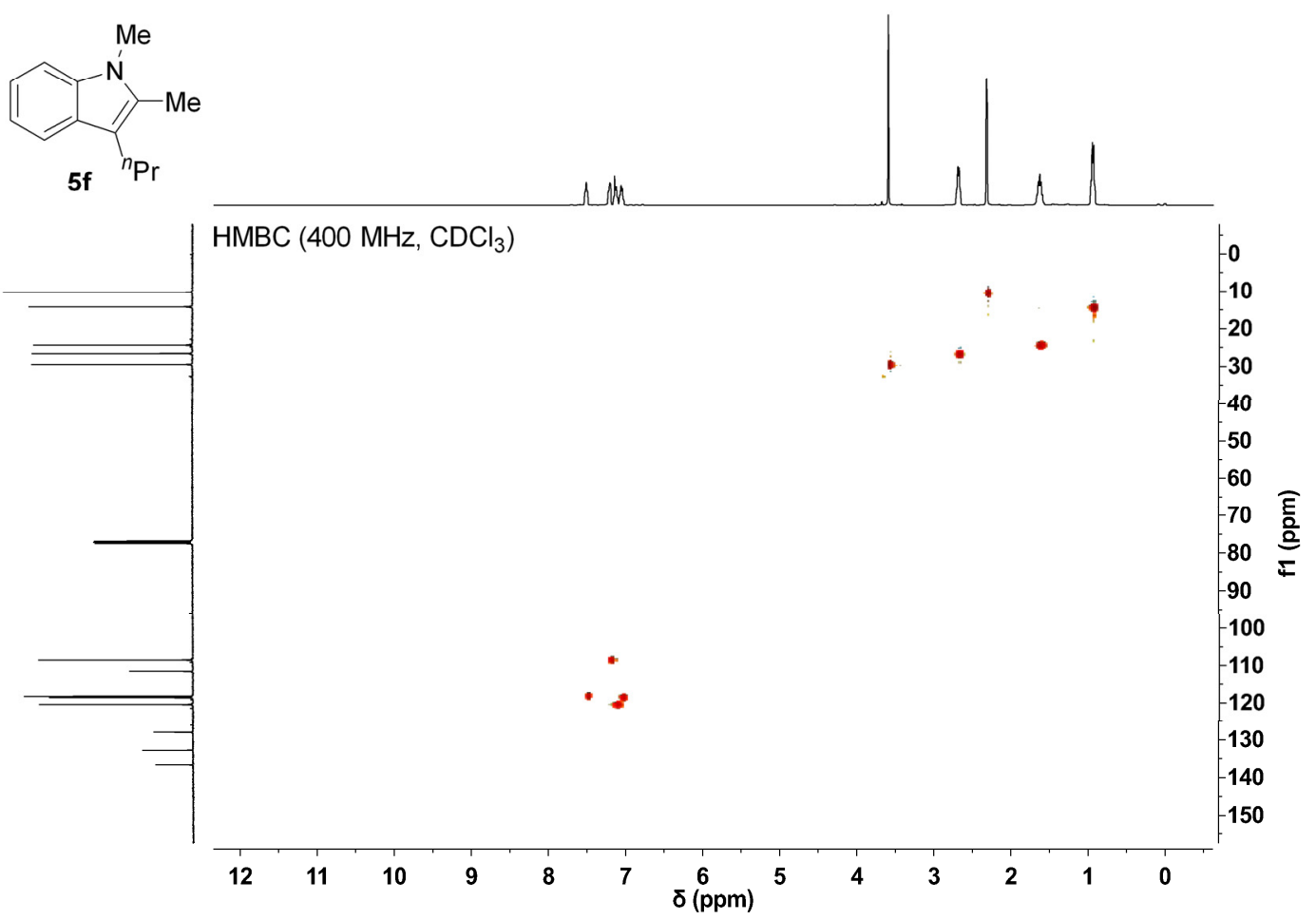

Figure S10. The $\mathrm{HMBC}\left(400 \mathrm{MHz}, \mathrm{CDCl}_{3}\right)$ of $\mathbf{5 f}$

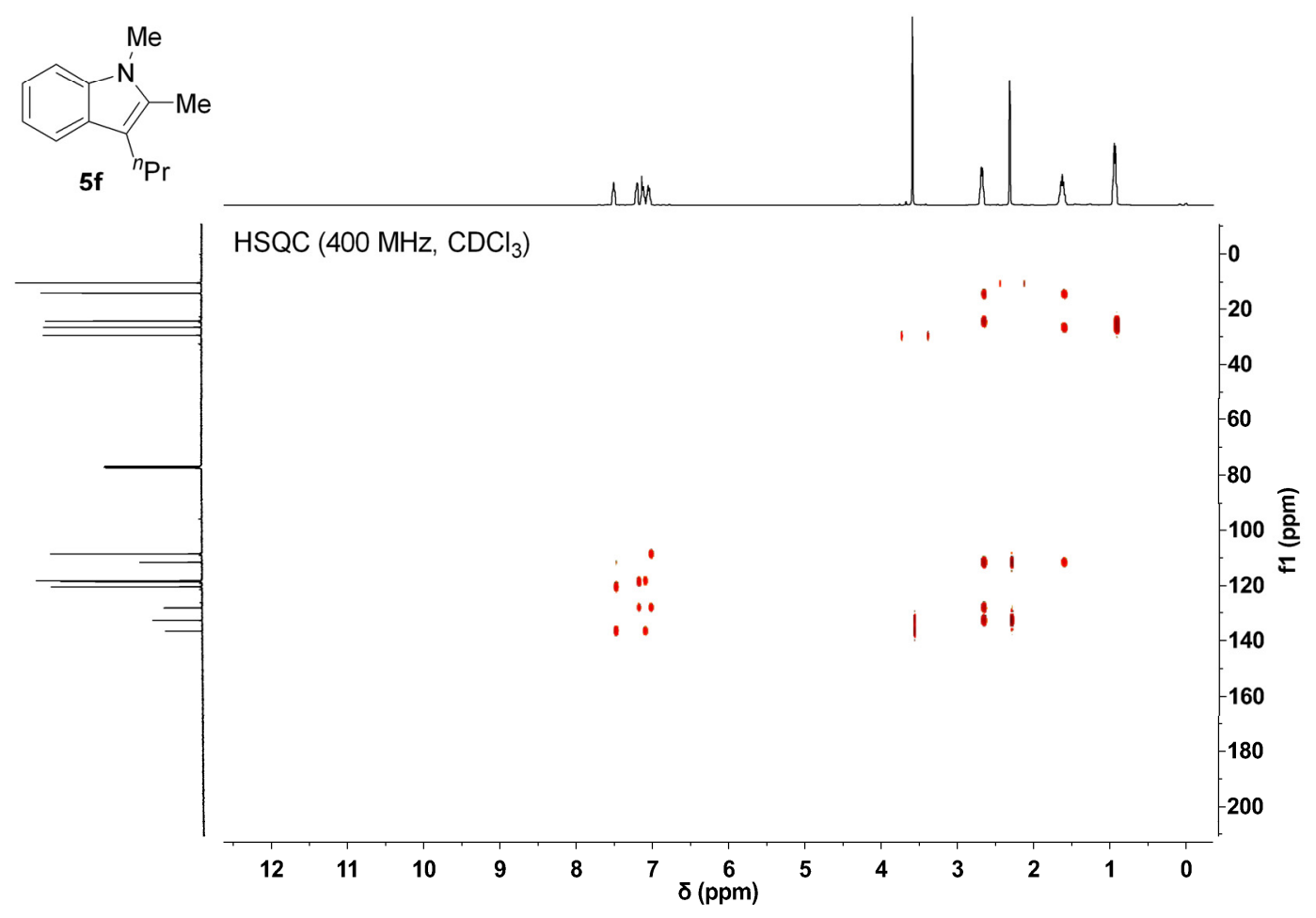

Figure S11. The HSQC (400 MHz, $\left.\mathrm{CDCl}_{3}\right)$ of $\mathbf{5 f}$

\section{References}

(1) (a) Yu, D.-G.; Gensch, T.; Azambuja, F.; Vásquez-Céspedes, S.; Glorius, F. J. 
Am. Chem. Soc. 2014, 136, 17722. (b) Sun, B.; Yoshino, T.; Matsunaga, S.; Kanaia, M. Adv. Synth. Catal. 2014, 356, 1491. (c) Sun, B.; Yoshino, T.; Matsunaga, S.; Kanai, M. Chem. Commu. 2015, 51, 4659.

(2) Luo, H.; Ma, S. Eur. J. Org. Chem. 2013, 15, 3041.

\section{NMR Spectra for All the Compounds}

